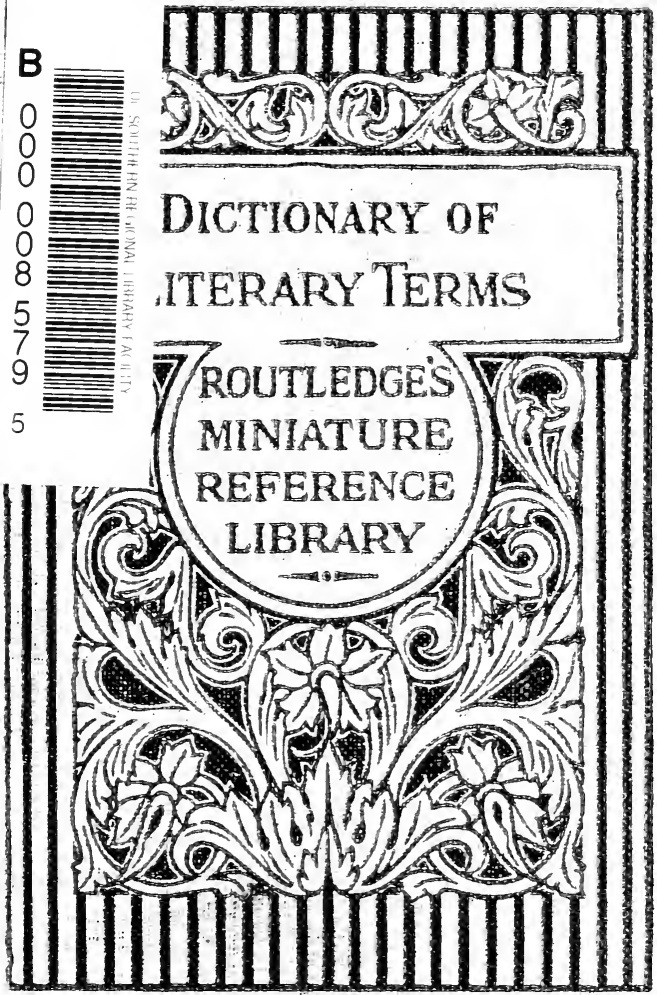




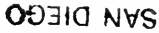 \\ VINYOAITZS \\ JO MLISUJAINO

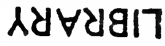




$$
\text { , }
$$



, 



\section{Tbe Miniature Reference Itbrary}

\section{LITERARY TERMS}




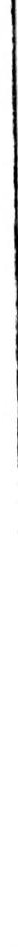




\section{A DICTIONARY OF \\ LITERARY TERMS}

BY

PERCIVAL VIVIAN

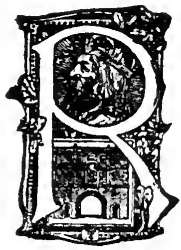

LONDON

GEORGE ROUTLEDGE \& SONS, LTD, NEW YORK: E. P. DUTTON \& CO. 


\section{Printed in Great Britain by}

wuilas Brendor \& Son. Ltd.. Plymoutb 


\section{PREFACE}

THis compilation is a glossary of literary terms. If it is sought to define the exact 'sense of 'literary terms' in accordance with which this collection has been made, we may get as near, perhaps, as we are likely to get, by saying that they are such words of specialized or technical meaning as constitute the vocabulary of literature, both in its primary sense of creation and in its subsidiary one of criticism. Of such words there are, broadly speaking, two classes: words belonging to the technology of literature, terms of craft, names of species and classes of literary and semi-literary compositions, phrases and terms of grammar, rhetoric, and prosody, etc., and words belonging to the vocabulary of literary criticism, includ. ing movements, periods, influences, schools, styles, virtues and vices, as well as such cant phrases as have received currency or acceptation. While the first class is capable, in most cases, of adequate definition the latter class is naturally intangible, and does not lend itself to clear-cut exposition; in such cases a definition may be an epigram, but it is seldom much more, and it is hoped that the paragraphs dealing 
with such terms will in all cases succeed in conveying an adequate knowledge or appreciation of the subject under treatment.

The field covered by the above definition of 'literary terms' is limited still further by the general purpose of such a book as the present, which must obviously give the preference to the terms of English literature. In the selection of foreign terms which space has made necessary, first place has been given to such as illustrate directly or indirectly either the development of English letters or their 'comparative' study.

In conclusion, it is believed that thisitompilation will prove useful to students and readers in general. The author has had the assistance of no previous work, and is not aware of the existence of one. 


\section{DICTIONARY OF LITERARY TERMS}

Abaser, The: The alternative title given by Puttenham in his Art of English Poesy to the figure of Tapinosis (q.v.).

Abecedarian Hymns: Hymns in which each stanza begins with the successive letters of the alphabet in their regular order, in imitation of the Hebrew acrostic poetry, as (e.g.) Psalm cxix.

Abecedarian Psalms: The term applied to twelve of the Psalms which are composed as acrostics, the most notable being Psalm xix.

Abode, Figure of: Puttenham's alternative term for Commoratio (q.v.).

Abuse, Figure of: The alternative title given by Puttenham in his Art of English Poesy to the figure of Catachresis (q.v.).

Acatalectic: A line or verse of poetry is said to be acatalectic when it is composed of the requisite number of complete feet, in contradistinction to a catalectic series, which is concluded by an incomplete or broken foot. Thus the regular Greek iambic metre is termed acatalectic, because it consists of six complete unbroken iambic feet, or their equivalents : 'Běā | tŭs îl | lě qūe | prǒcūl | nĕgō | tî̄s'. The hexameter line, however, is cata. lectic, as it concludes with an incomplete foot: 'Ārpî|nās ălǐ | ủs Völ | scōrum in | mōtutě sŏl | èbằt'. See also Procatalectic, Brachycatalectic, and Hypercatalectic. 
Accent and Quantity: The nature of rhythm re. quires that the component units of the succession should in some way differ from one another, for it is perfectly clear that a succession of units identically similar cannot constitute a rhythm. Regarding verse therefore as rhythmical language, there must be some 'differences' between the successive syl. lables which constitute the spoken rhythm; the nature of such differences has varied with races and languages, but the most important of them are Quantity and Accent. Both of these are, of course, based upon physical peculiarities of enunciation predominating respectively with certain races. Quantitatively, one syllable differs from another in taking longer to pronounce; accentually, one syllable differs from another in being uttered with a more vigorous expulsion of breath, though actually taking no longer in enunciation. Quantitative verse consists therefore in the rhythmical disposition of syllables pronounced in proportionately more or less time; accentual verse in the rhythmical recurrence of stresses. Though the Greeks possessed accents of various sorts, their poetry was primarily and univer. sally quantitative, and had an origin, naturally enough, closely connected with music, the affinity between quantity and musical time being sufficiently obvious. The relative length and shortness of the syllable was decided by reference to two considerations; some vowels being regarded as long 'by nature', as naturally taking a greater time to enun. ciate, others as long 'by position', the voice being compelled to dwell upon them by the fact of their preceding certain consonantal combinations. The Romans, though themselves possessing some sort of accent, and in their early indigenous Saturnian metre some accentual poetry, borrowed Greek metres wholesale. Latin poetry became therefore quantitative and remained so till the hymnologists ot the Christian era, when accentual verse appeared in Dies Ira and similar rhythms. Modern, i.e. post 
classical, poetry is generally accentual, and when terms of classical prosody are used in relation to it, it must be remembered that 'long ' is to be translated by 'thesis' or 'accented', short by 'arsis' or 'unaccented', the English trochee (e.g.) being merely a thesis followed by an arsis, and by no means equiva. lent to its classical namesake. The use of such terms is, however, misleading. Romance languages have less accent of this kind than English; Italian pronunciation approaches the quantitative; while in French what accent there is may almost be said to accommodate itself to the given rhythm. English has, however, a marked and stable accent capable of melodious and poetical combination, but little, if any, sense of quantity. Spondees are indeed occasionally met with, frequently in cases where one syllable of a dissyllable takes an accent naturally, while the other gets a supplementary accent on account of the necessity for emphasizing its sense, as 'far. fetched'.

Acromonogrammaticum: 'A poetical composition of which every verse begins with the last letter of the preceding line'.

Acrostic: A form of poetical composition in which the first, last, or some central agreed letter, when read successively in the order of the lines, make a word or sentence. Where the initial letters are taken, the lines are strictly acrostic; where the final letters are used, telestic; and where some central letter is employed, mesostic. Sometimes the letters are to be read upwards instead of down. wards; sometimes both initial and fianl letters form the acrostic, this variety being termed a double acrostic or telestich. There are various other refinements and complications, one of the most ingenious being Poe's Valentine, in which the acrostic is read by taking the initial letter of the first line, the second of the second, the third of the third, and so on. Acrostics are now, of course, 


\section{4}

excluded from serious literature, but were looked upon in high honour and even reverence by the Hebrews, certain of the Psalms, viz. those termed the Abecedarian Psalms (q.v.), being actually acrostics. Acrostics are found in the Greek Anthology, and Cicero (De Divinatione) states that they were found both in the Sibyllic verses and the poems of Ennius. In 326 A.D. Publius Porphyrius wrote a poem in acrostics in praise of the Emperor Constantine. They were also fashionable in French literature from Francis $i$ to Louis xiv, but it was reserved to the Elizabethan poets to carry them to the furthest excess, after which period they rapidly fell into disrepute as a form of literature.

Act: 'The part or division of a play performed consecutively or without a fall of the curtain, in which a definite and coherent portion of the plot is represented'. The traditional number of acts in a play is five, roughly corresponding to the 'episodes' of a Greek tragedy, the sections of the play separated by the stasima or choral odes.

Acyrology: The incorrect use of language.

Adonic: In classical prosody a foot consisting of a dactyl followed by a spondee or trochee, $-\cup v-u$; the last line of a Sapphic strophe.

Age of Prose and Reason: The description applied by Matthew Arncld in his Essays on Criticism to the eighteenth century of English literature as an age the chief merit of which consisted in its having evolved a splendid prose style, and liberated thought from the trammels of religious discussion, both to the detriment of poetry. "A fit prose was a neces. sity; but it was impossible that a fit prose should establish itself among us without some touch of frost to the imaginative life of the soul. The men of letters whose destiny it may be to bring their nation to the attainment of a fit prose, must of necessity, whether they work in prose or verse, give a predominating, an almost exclusive attention to 


\section{5}

the qualities of regularity, uniformity, precision, balance. But an almost exclusive attention to these qualities involves some repression and silencing of poetry.... Though they may write in verse, though they may be in a certain sense masters of the art of versification, Dryden and Pope are not classics of our poetry, they are classics of our prose'.

Agon: The term of Greek rhetoric for the contentious or argumentative part of a speech.

Agony Column: The column of a newspaper containing special or personal advertisements, particularly those for missing relatives and friends, whicb thus often gives evidence of great distress.

Albino-poets: A term arising out of a passage of Oliver Wendell Holmes's Autocrat of the Breakfast Table (chap. viii), in which he speaks of Kirke White as one of the 'sweet Albino-poets', whose songs he admires. The phrase carries a suggestion of etiolation and lack of robustness; possibly also a pun was intended.

Alcaic Verse: A strophic form of Æolian poetry, used, of Greeks, by Alcæus, its inventor, from whom it takes its name, Sappho, and other lyric poets; by Horace in Latin, who wrote thirty-seven odes in this metre. A good example is Tennyson's:-

' Ō mighty̌ moūthed īnvēntǒr ŏf hārmŏniěs.

O skillled tǒ sīng of tīme ŏr ětērnìty. Gŏd gîftěd ōrgăn vōice ŏf Eñglănd

Mìltŏn, ă nāme tŏ rěsoūnd fŏr āgēs '.

Alcmanian Verse: This metre consists of a series of distichs, the first line of which is a hexameter, the second a line of four dactyls catalectic, or short of the last syllable of the last foot, as e.g. -

'Laudabunt alii claram Rhodon aut Mytilenen Aut Ephesum, bimarisve Corinthi'.

This measure is used by Horace in Carm., $i, 7$ and 23, and Epod., xii. 
Alexandrianism: This word contains an allusion to the Hellenistic literature which flourished at Alexandria roughly from $300-146$ B.c., and which though brilliant was decadent, and derivative rather than original. 'Literature becomes a polite industry, in which success is to be achieved by obeying or inventing critical canons. Mannerism and affectation begin to invade it'. Hence the term 'Alexan. drianism' is applicable to an 'Indian summer' of literature, which, though splendid, has ne seeds of promise and no vigour of its own; which is chiefly imitative and derivative and rooted in decadence.

Alexandrine: A twelve-syllable line of iambic or trochaic rhythm containing six complete beats, as, e.g., 'And give resounding grace to all heaven's harmonies'. Alexandrines, though the usual vehicle of French drama, are not used consecutively in English poetry; they are used alternatively with 'fourteeners' in Poulter's Measure (q.v.), and frequently to terminate a passage of lyric verse (as in Milton's Comus) or a fixed form of stanza (as the Spenserian, q.v.). The former use was so overdone by versifiers that Pope condemned it in his Essay on Criticism. The name 'Alexandrine' may be derived either from a twelfth-century poem on Alexander written by Alexandre de Bernay and Lambert-Li-Cort, or from the Castilian verse chron. icle Poena de Alexandro Magno, both of which are in this metre.

Allæostrophic: An allæostrophic composition is one consisting of a series of strophes differing in struc. ture.

Allegory: A narrative constituting a sort of continuous or extended metaphor, each single character and action in which has an underlying sense, so that the whole. besides its obvious meaning, contains a relation of events in some other sphere or context, as, e.g., Pilgrim's Progress, the actors and events of 
which represent moral or spiritual attributes and consequences so that the relation is a history of spiritual life. Allegory differs from a Parable in that the latter is more concise, and pointed to inculcate a single lesson or principle. Fable differs from them both in being a narration of physically im. possible events, as, e.g., the conversation of animals and inanimate objects, with, of course, an underlying sense.

Alliteration: The repetition of the same letter or sound at the beginning of syllables following in close succession, as, e.g., Pope: 'Puffs, powders, patches, bibles, billets-doux'. Though the term alliteration is said to have been invented by Pon. tanus in the fifteenth century, the use of the figure was known to the Greeks and Romans. It is remarkable, however, as being a special characteristic of old Teutonic poetry (Anglo-Saxon, Middle-English, Old Saxon, Icelandic, etc.). The lines in alliterative poetry were divided into two sections, the first hav. ing two alliterative syllables, the second one, as in the following line from Piers Plowman: "Hire robe was ful riche, of red scarlet engreyned'. Occasionally, however, four or more alliterative syl. lables occurred. The alliterative syllables were always accented, and not necessarily the first syllables of the words in which they appeared. Chaucer's verse, though rhymed, contains a considerable amount of alliteration (as in, e.g., the Knight's Tale), and Spenser also affected it. It is usually condemned when used to excess in modern poetry, but is undoubtedly a source of beauty and strength when properly employed.

Alto Estilo: The title (meaning ' lofty style ') claimed by the Spanish writer and bishop Antonio de Guerara for the style of his book Reloj de Principes, or Dial of Princes (I529), which consisted of a curious 'artificial mincing dialect', full of antitheses and extravagances. The book was popular in Eng. 


\section{8}

land. It was translated by Lord Berners in $\mathbf{1 5 3 9}$ from a French version, and again by Sir Thomas North in 1537 ; and it probably contributed to the vogue of Euphuism (q.v.), though, as has been pointed out, this literary infection was very pre. valent in most European literatures at the time.

Amblysia ; Literally 'a blunting'; a term used by Servius meaning Litotes (q.v.).

Amœbean Poetry: The name given to the class of pastoral poetry which arose out of the contests of shepherds in song for a prize. The fashion of these competitions may be gathered from the artificial representations of them in the Idylls of Theocritus and Eclogues of Virgil. The competitors sang al. ternately, matching song against song, and the poem was perpetuated in the conventional pastorals of the above-mentioned authors and others. The style is distinctively Dorian and especially Sicilian; it is generally accompanied by the e'ersus inter. calaris, or refrain. The amcebean form is also found in the early Roman saturæ, where, however, it had a different origin, being a variety of dialogue. The word itself means 'alternate'.

Amoret: A love soniet or song. Cf. 'Rather pass away the time here in these woods with writing amorets ' (Lodge's Euphziês' Golden Legacy).

Amphiboly : See Amphibologia.

Amphibologia, Amphibology, or Amphiboly: (r) Ambiguous discourse; a sentence which may be con. strued in several ways; a quibble. (2) The figure of speech denoting the ambiguity arising from an uncertain construction, the individual words of which are not themselves equivocal, distinguished by lo. gicians from equivocation.

Amphibrach: The metrical foot consisting of a long syllable between two short ones $(\checkmark-u)$. It is de. rived from the Greek $a \mu \phi i$ and $\beta \rho a \chi i^{\prime}$, as signify. ing short on both sides. It is thus the converse of the Amphimacer (q.v.). 
Amphigouries: A variety of nonsense verse whicb originated in France in the seventeenth century, consisting of high-flown sentiments and elaborate diction without any meaning whatever. The original style of amphigouri was calculated to give the reader the im. pression that there was a meaning though it were shrouded under some obscurity, and the result was, of course, a hoax. Fontenelle is said to have been deceived in this fashion, and to have retorted, when the deception was pointed out, that the verses in question were so much like other fine verses he had heard that it was not surprising he was mistaken. Of this type of amphigouri is Pope's Song by a Person of Quality. Lycophron's Alexandia (third century B.C.) is suspected of being an example, but it is probably nothing but obscure. Later varieties have been more overtly nonsensical, as those of Lewis Carroll, Lear, and Barry Pain.

Amphimacer: The metrical foot consisting of a short syllable between two long ones $(-v-$ ). It is derived from the Greek a $\mu$ фipakpos, long on both sides. It is aiso called a Cretic.

Amplification: See Auxesis.

Ampulla: The Latin term for literary bombast, turgidity of style.

Ana, The: The class of such works as Benthamiana, Scaligerana, viz. collections of obiter dicta, stray thoughts and striking passages of those respective authors; miscellanies of their thoughts or teachings.

Anachronism : The chronological confusion of representing as coexistent things that never could have coexisted. The term should strictly be applied to cases where in a scene or background of any given period something is introduced by anticipation which had not at that time come to exist, as (e.g.) the clock in Shakespeare's Julius Casar. It should thus be distinguished from Parachronism (q.v.).

Anacoluthon: The grammatical term denoting the 
absence of syntactical sequence where the gram. matical construction with which a sentence is begun is not continued, but abandoned for another.

Anacreontics: The name applied to a metre originally or chiefly employed by Anacreon of Teos, a Greek lyric poet, who flourished about 530 B.C. He wrote in a dialect mainly Ionian, but in the matter and form of his lyrics he was rather akin to the Eolian school. The metre to which he has given his name is an iambic of three and a half feet, either iambi or spondees with an occasional anapæst in the first foot, as, e.g. 'E $\rho \omega s \pi 0 \tau$ ' $\dot{\epsilon} \nu$ pó $\delta o \iota \sigma l$, one of the poems included in the collection which bears his name. This collection, however, which consists of about sixty short pieces, was compiled in the tenth century, and there are few genuine fragments of his work. The spurious Anacreontea are all of the Christian era, it is thought, some of them being as late as 500 A.D. The subject of these poems, whether genuine or spurious, is generally love, wine, and feasting; they are the dainty trifles of a poet of pleasure, basking in the warmth of a gay and brilliant society. In style they are delicate and well finished with a cameo-like elegance, though often devoid of real inspiration. Hence the name Anacreontics is frequently applied to such elegant trifles in other languages couched in the same spirit and exhibiting the same gem-like finish.

Anacreontic Verse: A Greek Ionic measure so called on account of the attribution to Anacreon of many poems written in it. It consists of two Ionics a minore

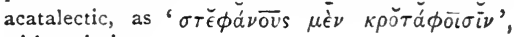
with variations.

Anacrusis: The extra-metrical syllable or syllables at the beginning of a line of poetry. Thus, scan. ning 'Hath | melted like | snow in the | glance of the | Lord', as dactylic, the first syllable 'Hath' is an anacrusis, as extraneous to the metrica scheme. 
In this sense the term is borrowed from music, in which context anacrusis meant the up-beat before the beginning of the bar.

Anadiplosis: The grammatical figure consisting of the repetition of a word from one sentence at the commencement of the next, where it has logical as well as verbal importance as the starting-point of a fresh thought logically consequent upon the last, e.g., 'The stick began to beat the dog; the dog began ', etc.

Anagnorisis: Anagnorisis or Recognition is a part of the Aristotelian theory concerning tragedy laid down in the Poetics, and, like Peripetia (q.v.), one of the ingredients in the 'complicated 'variety of plot which assist in conducting it to the climax. It is defined as 'a change from ignorance to knowledge, producing love or hate between the persons destined by the poet for good or bad fortune'. Like Peripetia it turns upon a surprise: both are potent means of dramatic rearrangement of a situation.

Anagram: The transposition of the letters composing one or more words into one or more new words usually involving some point of allusion or connection in meaning: e.g. 'Honor est a Nilo' is an anagram of 'Horatio Nelson'.

Anagraph: A transcript or copy of any record or document.

Analecta : Literary extracts, fragments, or selections.

Analogy : A similarity of relations subsisting between two things; hence the method of argument based upon such similarity where induction is not complete.

Anapæst; The metrical foot consisting of two short syllables followed by one long $(u \checkmark \neg)$.

Anaphora: The rhetorical figure of the repetition of a word or phrase at the beginning of consecutive verses or entences; as Shakespeare, As You Like It: 
'If ever you have look'd on better days, If ever been', etc.

Anastrophe or Inversion: The transposition of words out of their natural order for the sake of emphasis, metre, rhyme, or literary effect of any sort, as Milton, Lycidas: 'The Muse herself that Orpheus bore'.

Anceps, The: In classical prosody the concluding syllable of any complete 'verse' or metrical line may be either long or short, as in either case the voice pauses upon it slightly, and its quantity can have no effect upon the following verse. Such a con. cluding syllable is called the Anceps (Latin, 'doubtful').

Annomination: The emphatic opposition of words of the same sound but different meanings, not necessarily with a punning intention; sometimes, however, where such intention is present, equivalent to Paronomasia (q.v.).

Annus Mirabilis (Latin, 'Wonderful Year'): A term applied specifically in English history to the year 1666, which was noted for several famous events, including the Great Fire and the defeat of the Dutch fleet, and concerning which Dryden wrote a poem bearing the above title. Hence the phrase has been applied to any year memorable in public or private bistory, and in connection with an author to the year of his finest or most remarkable produc. tions. Thus, for example, one of Coleridge's critics called 1797 his annus mirabilis, as during that year the poet composed most of his finest works; and Natthew Arnold, alluding to Wordsworth (Last Words on Translating Homer), speaks of 'the time he composed Ruth, -his great time, his annus mirabilis, about 1800 '.

Antanaclasis: ( $\mathrm{r}$ ) The rhetorical figure of the repetition of a word in a different or contrary sense, as, e.g., 'In thy youth learn some craft that in thy old age thou mayest get thy living without craft'. 
(2) The rhetorical figure of the return to a subject after a long parenthesis, as, e.g., 'Shall that heart (which, etc. etc.), shall that heart, I say, etc." In sense ( 1 ) it is applied to the pointed repetition of an opponent's or previous speaker's words in a different sense or with a different inference.

Antanagoge: The rhetorical figure of accepting an imputation or statement of the opposing side, and at the same time making up for it or discounting it by urging other considerations. The term is also applied to the rhetorical trick of retorting upon one's adversary the charges he brings against the speaker when they cannot be rebutted. Puttenham in the Art of English Poesy gives this figure the English name of 'The Recompenser'.

Antapophora: The rhetorical figure in which the writer or speaker puts a question and proceeds to answer it himself.

Antenclema: The term of rhetoric for the figure of justification; admitting an opponent's allegation and justifying it.

Antepenult: The syllable before the last two. Antepenultimate is an adjective denoting last but two; applicable to anything; usually, however, to either a syllable or letter.

Anthology: 'The Anthology' par excellence is the Greek Anthology, a collection of epigrams and short pieces of verse, ranging in date from Simonides of Ceos (49) B.C.) to the sixth century of the Christian era. The first was that of Maximus Planudes (I330 A.D.), a Byzantine monk, founded upon that of Agathias ( $55^{\circ}$ A.D.), in seven books. In 1606 Salmasius or Saumaise found another Anthology in the Library of the Elector Palatine at Heidelberg (hence styled the Palatine Anthology), compiled by Constantinus Cephalas about 920 A.D., of which that of Planudes is now admitted to be a mere re. arrangement or abridgment. The word, however, 
which means a garland or bouquet, is generally applied to any selection of verse, lyric or epigram. matic, more rarely to a selection of prose passages.

Anthorism: The rhetorical term for a counter-definition in argument.

Antibacchius: The metrical foot consisting of two long syllables followed by a short one $(--v)$. It is so called because it is the converse of the Bac. chius (q.v.).

Anticlimax: The opposite of Climax (q.v.), viz. 'a sentence in which the last part expresses something lower than the first; more generally, however, bathos; the addition of a particular which, instead of heightening the effect, suddenly lowers it, or makes it ludicrous' ( $V . E . D$.$) .$

Antidactyl: Another name for an Anaprest (q.v.).

Antigraph: A copy, transcript.

Antimasque: $\operatorname{Sec}$ Masque.

Antimetathesis: The rhetorical figure of putting the reader in the place of an actor or spectator by force of vivid narration.

Antiphrasis: The use of words in a perverted sense, opposed to the proper one, as 'Lynch law', which is no law; 'Scarborough warning', which implies surprise without warning. Also the rhetorical term for the species of derision 'when we deride by plain and flat contradiction, as he that saw a dwarf, said, "See yonder giant" (Puttenham).

Antispast: The rhetorical foot consisting of an iambus followed by a trochee $\left(u-\_\right)$; from the Greek à $\nu i \sigma \pi a \sigma \tau o s$, drawn in different directions. Antistrophe: See Strophe.

Antithesis: The opposition, by way of pointed contrast, of different words or expressions, as 'Render unto Cæsar the things that are Cæsar's, and unto God the things that are God's'. In another sense the word signifies a variety of Metaplasm (q.v.). 
Antonomasia: The use of a descriptive phrase, patronymic, title, or nickname, etc., instead of a proper name, as the 'Iron Duke', the 'Emerald Isle', the 'Son of Peleus'.

Anușțubh : See Çloka.

Aphæresis : See Metaplasm.

Aphesis: The term invented by Dr. Murray for the philological process which a word undergoes in losing its initial letter or syllable. Such 'aphetic' words are usually of French derivation, as 'cates' for 'acates'; among English examples we may notice 'down' for 'adown', 'lone ' for 'alone'.

Aphorism : Originally and strictly a brief definition or statement of principle in some particular science or art; hence generally a maxim or proverbial saying.

Apocope : See Metaplasm.

Apodosis : See Conditional Sentence.

Apologue: A fable related with special application to the circumstances of a case in point, as Nathan's parable to David concerning Bathsbeba, or the fable of the belly and the members in Coriolanus.

Apopemptic Poem : A valedictory poem addressed to one about to set out upon a journey, as Horace, Odes, i, 3 .

Apophoreta : See Posy.

Apophthegm: A brief sententious utterance, a maxim or terse proverbial saying.

Aporia: A rhetorical figure which according to Puttenham is so called 'because often times we will seem to cast perils and make doubts of things when by a plain manner of speech we might affirm or deny them'. His English name for the figure is 'The Doubtful'.

Aposiopesis: The rhetorical figure consisting of the abrupt breaking off of a sentence before its con. 
clusion, either for effect of some sort or because a second thought follows so swiftly on the heels of the first as not to give the latter time for its complete expression, as Milton, Lycidas: 'Had ye been there . . For what could that have done'; or Virgil, Eneid: 'Quos ego ....'

Apostrophe: The rhetorical figure which consists of breaking off from some previous method of address to address some person or thing in the second person, as De Quincey: 'Dismissing hernot to any Thessalian vales of Tempe, but-O ye powers of moral anachronism-to the Chester Post Office'.

Apparatus Criticus: A collection of materials for any work of literary criticism.

Arbre fourchu: See Lai.

Arcadia: The land of conventional rusticity, of 'piping shepherds and coy shepherdesses'. It is interesting to note that while the pastoral style of writing was derived from Theocritus, Bion, and Moschus through Virgil and Sannazaro, none of the Greek originals placed their poems in Arcadia, though that country has since become so closely identified with all conventional pastorals. The background of the Greek pastorals was chiefly Sicily; 'neither Theocritus nor his early imitators laid the scene of their poems in Arcadia; this imaginary scene was first adopted by Sannazaro' (Mahaffy).

Archaism: The employment of antiquated words and phrases; or such a word or phrase itself.

Archebuleus Versus; This measure, which was used by the Alexandrians, consists of three dactyls with

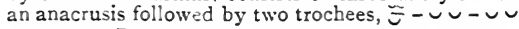
-レレーレーこ.

Archilochian Verse: The dactylic semipentam ter, $-\smile v-\smile v \mid-$, so called because it was much used by the Greek lyric and satirical poet Archilochus of Paros, who flourished about 700 B.C. 


\section{7}

Aristophaneus Versus: See Laconic Verse.

Arsis and Thesis: Terms used in Greek prosody (and thence drawn into general employment) signifying respectively the raising and setting down of the foot in the dances of the Greek chorus, those actions corresponding with the short and long syllables of the lyrics which were simultaneously sung, just as in ordinary march music the musical accent coincides with the beat of the foot. On this account the term arsis, the raising of the foot, was applied to the short or unaccented syllable, while the term thesis was used of the long or accented syllabie. It happens, however, that the terms were also used of the elevation or lowering of the voice in the accommodation of its pitch to the quantities of the verse recited, and hence the meanings of the terms became the exact opposite of those they had originally borne. In Latin and modern prosody arsis is the accented syllable and thesis the unaccented, though recent writers have returned to the more correct interpretation of the words.

Arte Mayor: licrsos de arte mayor, to give the full title, or 'verses of superior art' (so called because they were thought to require superior skill in composition compared with the older Redondillas, q.v.), were a species of Spanish metre consisting of stanzas of dactylic rhythm. They had their origin, according to some authorities, in Galicia and Portugal, but the form is found in some of the most ancient Cas. tilian romances. They were rhymed on two rhymes to each stanza, which consisted of seven or eight lines. The earlier examples are rugged and much resemble the early English ballad poetry. This metre, which became predominant in Spain in the latter part of the fourteenth century, was revived by Cervantes.

Artificial Comedy: A term sometimes applied to the Comedy of Manners (q.v.). 
Arthurian Cycle: The cycle of romantic legend woven round the personality of Arthur, the great mythical (or semi-historical) king of Britain. There are two main phases of the general legend, the earlier, which had sprung into existence by the beginning of the thirteenth century, and was mainly concerned with the king's exploits against Saxons and Romans, and the more complete condition to which the story attained by its gradual development throughout that century, and which practically consists of two inter. woven legends, the Quest of the Holy Graal and the love of Lancelot for Guinevere. The germ of the cycle was Geofirey of Monmouth's History (in Latin), which became very popular. It was turned into a metrical chronicle by Wace (Brut d'Angle. terre, I155), and followed by Layamon's Brut, in which the distinctively Arthurian legend begins to take definite form. The other elements of the legend now begin to appear with the French versions by Chrestien de 'I royes and Robert de Borron of still earlier Latin romances on the story of the Graal, and the French prose romances of Lancelot and the Queste del Saint Graal (possibly both by Walter Map). Thereafter the story grew either by subse. quent invention or by the incorporation of uncon. nected legends, such as the Tristram romance, which is admittedly Celic.

Asclepiad: A metre used by Ionian, Æolian, and Roman lyric poets, consisting mainly of choriam. bics, as $-\smile|-\smile \cup-|-\smile \cup-\smile \succeq$. Besides the single line used alone, as in Horace, Odes, ii, 'Mrce. nas atavis edite regibus', there are four main ascle. piad strophic forms:-(r) Consisting of a distich:

' Sĩc tē | divă pǒtëns Cy̆prì

Sîc frā | trēs Hělěñ̄ | lūcĭdă Siděră'

$$
\text { (Horace, Odes, i, 3). }
$$

(2) Consisting of three of the single asclepiad lines followed by a fourth line, - - | - $-\cup \succeq$, as Horace, 
Odes, i, 6. (3) Consisting of two pure asclepiad lines followed by two lines:

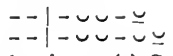

as in Horace, Odes, i, 5. (4) Consisting of single lines of the following structure: $--|-\smile \cup-| \backsim \checkmark$ $-\mid-\cup \cup-u \succeq$, as in Horace, Odes, i, Ir. Occasionally to the metre consisting of the pure asclepiad line repeated by itself is given the name of the First Asclepiad; No. r above being termed Second Asclepiad, and so on.

Asianism : The florid style of oratory which came to be in vogue in the schools of Asia Minor after the downfall of free political institutions in Greece. 'Its main feature was display, sometimes in the direction of bombastic inflation, sometimes in that of brilliant antitheses and conceits. In sharp con. trast with the best classical work in any form of art, the whole was less thought of than the parts; and any kind of tinsel ornament was used without taste or self-restraint'. Its tendency was corrected to some extent by the counter-influence of Atticism (q.v.). See also Rhodianism.

Assonance: A species of imperfect or incomplete rhyme, consisting of the use as a substitute for rhyme of the same vowel sounds, but different consonants. Thus 'man', 'can', are rhymes; 'man', 'cat', are assonances. Assonance is particularly common in Spanish poetry and the early French chansons de geste; it was generally a precursor of complete rhyme.

Asteism: The rhetorical term for inoffensive pleasantry; also termed by Puttenhan 'the merry scoff' or 'civil jest'.

Astrophic: A term of Greek prosody applied to choral odes not divisible into the usual divisions of strophe, antistrophe, and epode (though the last was sometimes wanting in the regular form). More 
generally it is applied to poetry not capable of resolution into regularly recurring stanzas, such as the irregular odes of Gray, or Theocritus' epithalamium upon the Marriage of Menelaus and Helen. Asynartete: The absence of grammatical connection between clauses or sentences.

Asyndeton: The omission of connecting particles between clauses or sentences, as 'Veni, vidi, vici'. Atellan Plays: The Atellan plays, or Ludi Osci, were a class of rustic comedy or farce performed at Atella in Campania; they belonged to the earliest period of Roman literature and were indigenous, owing nothing to Greek models. Originally simple and coarse farces, they were gradually elevated to a species of burlesque. They were represented on the Roman stage as interludes, one of the characters being apparently a sort of clown who created amuse. ment by his antiquated Oscan dialect. See Com. media dell' Arte.

Athetesis: The marking of a word or passage in an author as spurious or corrupt.

Atmosphere: A cant word of literary criticism denoting the success of a literary work in steeping the reader or spectator in the spirit of the scenes or times it depicts. The sense is apparently transferred from the technology of painting, in which, however, it bears a meaning not quite parallel.

Atticism: A term applied to the style in rhetoric based upon the best Attic models in revulsion from the Asianism (q.v.) or florid style of the schools of Asia Minor which sprung up in consequence of the decline in taste which accompanied the decay of free political life in Greece. The Atticists set up for models the earlier orators of the best period of Attic prose, and while they did not actually found a school of oratory in Greece, their criticisms were valuable, and they exerted an important influence upon the development of Roman oratory. See also Rhodianism. 
Aubade, Aube: The Gallicized form of the Provençal 'alba' or 'dawn-song'. This has been extended in meaning until it has been applied to any sort of early morning song, such as Davenant's "The lark now leaves his watery nest', and Shakespeare's 'Hark, hark, the lark', in both of which a lover calls upon his mistress to wake. Originally, however, it was the song of the lover constrained by the advent of dawn to leave his mistress' side; it contained such conventional features as the reluctant cry of the lover that it is the nightingale that is heard and not the lark, the harbinger of day; or the voice of the watcher on the tower giving warning that the clandestine meeting must end. The famous passage in Romeo and Juliet is therefore a true aubade.

Aufklärung: Aufklärung (German; lit. enlighten. ment) or 'Illuminism' is the term usually giver to the general rationalistic movement in Germany in the eighteenth century, under the influence of Wolff's exposition of Leibnitz's philosophy. It has also been called 'The Enlightenment'.

Augustans: A term originaliy applied to the Latin authors of the time of Augustus Cæsar, usually regarded as the best period of Latin literature. Hence it has been applied to the writers of the reign of Queen Anne (and George i), regarded either as the corresponding zenith of English letters, an assumption which can hardly now be admitted, or as a period of classical correctness and purity of style. The parallel suggested by the name is difficult to justify: the period contains no English Virgil, and Pope can hardly be regarded as an English Horace. A better parallel for Horatian urbanity and geniality is to be found in Addison's prose rworks. The actual limits of the English Augustan age have been put at from r7oo, the date of Dryden's death, to 1726 , the date of Thomson's Winter. Though Pope lived on till nearly the middle cf the 
century, most of the definitely Augustan literature had been produced by 1726, and the appearance of Thomson 'marks the beginning of the slow return to nature in poetry' in reaction from the ideal of 'correctness'.

\section{Aulic, The: See Illustrious, The.}

Aureate: An epithet applied to literary style denoting splendour, richness, adornment.

Auto: Autos Sacramentales, to give the full term, were a variety of Mystery (q.v.) peculiar to Spain, and dealing, as the adjective implies, with the my'stery of the sacrament. They have been confounded with plays on the lives of the saints (I idas de Santos) or miracle plays, but they are a distinct variety. 'Auto' of course means 'act'.

Autonym: 'A book published under the author's real name'.

Auxesis or Amplification: The rhetorical term for the 'enrichment of discourse by epithet and image and graphic detail, word painting'.

Bacchius: The metrical foot consisting of a short syllable followed by two long ones ( --$)$.

Bacchylideum Metrum: This metre, which is said to have been used by Bacchylides, is a line of six cretics acatalectic.

Badin : See Vice, The.

Baifin : In 1574 Jean Antoine de Baif wrote his Etrenes de poëzie francoëse en wers mesurés. The verse in which it was composed, called after him 'baifin', is not a vers mesuré, but consists of rhymed fifteen-syllabled couplets with a cæesura after the seventh syllable, as, e.g.-

'Muse, royne d'Elicon | fille de memoire, o deesse, O des poetes l'appui, | farorise ma | hardiesse'. 


\section{3}

Ballad: The ballad has been defined by Mr. W. Sharp as a 'lyrically dramatic expression of action or events in the lives of others'. Apart from modern revivals, English ballad-literature comprises a considerable body of early poems half lyrical, half epic, narrating deeds of prowess or tales of love, usually rugged in diction and versification, but vigorous and often strikingly poetical. Most of them were handed down by oral tradition, and sung about the country by itinerant minstrels and harpers. The collection of some of them by Bishop Percy and their publication in his Reliques conduced to the Romantic Revival in England by stimulating interest in popular romantic literature.

Ballade: A poem of fixed form consisting of three, or occasionally five stanzas of an equal number of lines of equal length concluded by an 'envoy' or final half-stanza. The stanzas may contain any number of lines, which may be of any length. Each stanza must contain the same rhymes in the same order, the envoy reproducing the rhymescheme of the latter half of each stanza, while the last line of both stanzas and envoy is the same repeated in refrain fashion. Ballades are frequently composed either of three huitains and a quatrain, or of three dizains and a quintain, but there is no rule as to this. The ballade had a considerable vogue in the fifteenth century of French literature, which it owed to Villon, and not to Marot, as Boileau affirmed. It was condemned by Du Bellay, Vauquelin de la Fresnaye, Molière, and Boileau, but it recovered its popularity in the hands of Théodore de Banville and Jean Richepin.

Ballat-royal: The name by which James i refers to Ottava Rima (q.v.) in his Reulis and Cautelis, etc. $\left(15^{8} 5\right)$.

Barbarismus or Barbarism: The use of words or expressions not in accordance with the classical standard of a language, especially such as are of 


\section{4}

foreign origin; hence rudeness or unpolished condi. tion of language $(N . E . D$.$) .$

Baroque: A term apparently derived from the jeweller's art, but considerably extended in meaning and often applied to literary style. It means grotesque, odd, whimsically adorned.

Bas bleu: See Bluestocking.

Basis: In classical prosody a line consisting of a single "metre"; a nonometer.

Bathos: Ludicrous descent from the elevated to the commonplace in writing or speech. The meaning of the word in this sense was originated by Pope in his essay parodying Longinus $\mathrm{O}_{n}$ the Sublime, of which word it is the converse in Greel.

Battology : Lit. 'stammering speech' ; so, vain and tiresome repetition in writing or speech.

Beast Epic : Se' Roman de Renard.

Beiles-Lettres: Polite literature, with a view not to subject-matter, but to form, history, literary criticisn, etc.

Bernesctie: A term appiied to literature of a light mocking nature. It is clerived from the name of an Italian poet, Francesco Berni (born c. I499; died 1535), author of Rime burlesche, and a rifacincnto of Bocardo's (M-lindo Innanorato, whose style was marked by a peculiarly mocking kind of satire, teening with lively humour and innumerable "equiv. oques'. Hence the adjective was applied to works of a sinilar character.

Bestiary : The hestiaries, which had a great vogue in the Middle Ages, were books concerning the supposed habits and peculiarities of animals. Being themselves a development of the earlier Physiologi (q.v), in which the habits of animals served as texts for symbolic devotional treatises, they were not concerned with fact or scientific knowledge, but with the legendary lore which at that period served 
in its stead, often too with a moral flavour. Many of the common sayings of the present day, as, e.g. the faithfu!ness of the dove and the parental self. devotion of the pelican, can be traced to these works. Among examples may be cited the Destiaire of Philippe de Thaon (twelfth century). a Besticire Diuin by Guillaume le Clerc (thirteenth century), and a Bestiaire d Amour, by Richard de Fournival (thirtesth century). There were also numerous English trans'ations of bestiaries, which with 'volucraries' and 'lapidaries,' contributed an important element to Euphuism (q.v.).

Bibliognost: One who linows about books and things relating to books. He is "one knowing in title pazes and colophons . . and all the minutix of a bool: (D'Israei).

Bibliograph, or Bibliographer: A writer or copytst of books, a scrivener; or o.ze who writes about books, their authors, editions, etc.

Bibliography: The practice of a bibiograph; or, more usuaily, a iist of bos':s of a particular author, printer, or country; or of those dealing with any particular theme or subject-matter.

Bibliomane or Bibliomaniac: One suffering from Bibliomania (vide infra).

Bibliomania: A rage for collecting and possessing books, on account of the rarity of their edition, printing, binding, etc., without reference to their value as literature.

Bibliopegy, Bibliopegist: Tookbinding; a bookbinder.

Bibliophile: A lover of books; a book-fancier.

Bibliopole: A bookseller.

Bibliotaph: A person who buries books by keeping them stored up under lock and key.

Blank Verse: Unrhymed English heroic or decasyllabic verse with iambic or trochaic rhythm; the usual vehicle of Elizabethan drama. 
Blason: The name of a variety of French poem con. sisting of short lines with rimes plates (q.v.), expressing either eulogy of some person, or complaint. Hence, more generally, the class of poetry that revels in the perfections of some feature in the poet's lady-love-'a woeful ballad made to bis mistress' eyebrow'. 'This style of literature was popularized by Clèment Marot $(1496-1544)$ and his school.

Blood, Tragedy of: The term applied by J. A. Symonds in his Shakspere's Pretlecessors to the more lurid type of Elizabethan drama, full of blood. shed, murder, and repulsive horrors, such as Kyd's Spanisi Tragedy, Marlowe's Jeil of Malta, Shakespeare's Tinus Antronicus, and some of the f'ays of Marston, Webster, and Tourneur.

Blue-stocking, A Blue: A term denoting a learned lady, with some connotation of pedantry. Accord. ing to Boswell, certain literary clubs came into existence in 1781 to which persons of both sexes were admissible. A prominent and constant frequenter of their meetings was one Mr. Sillingfleet, gravely dressed and in blue stockings, from whom the term took its rise. Translated into French as Bas blew it is current in the same sense.

Boiscius Versus or Versus Octonarius: This is the iambic tetrameter acatalectic, the line consisting of eight complete iambic feet, with variations and resolutions. It was used by the Romans in dramatic dialogue.

Bomphiologia: Turgid or bombastic diction (Puttenham).

Boos-plate: A book-plate or ex-libris is a label, usually pasted inside the front cover of a book, bearing the name, device, coat-of arms, crest, badge, or any design signifying its ownership.

Bookworm: The name given to the larvæ of various insects (particularly the two beetles Anobium pani. 
ceum and Ptinus brunneus) which eat into the paper and binding of unused books. By transference also, the word denotes one devoted to the study of books and wrapped up in them; in this sense it is as early as Ben Jonson's Cynthia's Rezels.

Border-Thief School: The term invented by Carlyle in Sartor Resartus and applied to the school of fiction represented by Sir Walter Scott and his imitators.

Boustrophedon: This term, applied to certain ancient inscriptions in Greek, Hittite, and other languages, signifies that they are written first from right to left. then from left to right, and so on in the same fashion, like the course of the plough, which turns round at the end of a furrow and cuts the next in the opposite direction. This practice is intermediate in the history of written languages between the Semitic practice of writing from right to left and the later Greek practice of writing from left to right.

Bouts-Rimés (lit. 'rhymed ends' ; French): A form of literary amusement consisting of the fitting of verses to given rhymes. According to Ménage, the idea was derived from the following occurrence. The poet Dulot complained one day that he had lost 300 sonnets, and, in the surprise that greeted this statement, let slip the confession that they were not complete sonnets, but mere skeletons, consisting of the rhymes alone. The incident created much amusement, and suggested the game, which soon became a craze, first in France and later in England, where at the beginning of the nineteenth century it attained to the dignity of public competitions at Bath and societies founded solely for its practice.

Bow-wow Theory: See Onomatopœia.

Bowdlerization: An expurgated version or edition; so called from the name of Dr. T. Bowdler, who 


\section{8}

published in 1818 an edition of Shakespeare 'in which those words and expressions are omitted which cannot with propriety be read aloud in a family'.

Brachycatalectic: This term and that of Hypercatalectic (q.v.) are only applied to lines scanned not in single feet, but in dipodies or pairs of feet, viz. in iambic, trochaic, and anapestic metres. One of such lines is said to be brachycatalectic when the last dipody wants its second foot, i.e. where the series concludes with a foot instead of a dipody. Thus 'Ŏf mān's first dīs | ŏbēdiěnce, ānd I thĕ frūit' is brachycatalectic, the complete dipodic series being represented by a line such as 'Añd give rěsoun! ding gräce tǒ āll | Heăven's härmŏnies |'.

Brachylogy: The grammatical term for a terse com. pressed form of expression or style.

Broad Flout, The: Puttenham's alternative term for Antiphrasis (q.v.).

Broadsheet : A sheet of paper printed on one side only, forming one large page; hence a ballad or piece of ephemeral literature printed in this fashion. Also ca!led 'Broadside '.

Broadside : Sec Broadsheet.

Brochure (lit. 'something stitched together'; French): A little pamphlet or booklet. The term is especially applied to a monograph or article upon some par. ticular subject printed in book form.

Bucolics : Poems purporting to be sung by herdsmen; pastoral poetry in general.

Bull : A sentence expressing inconsistent and incom. patible ideas or phrases; a species of humour tra. ditionally belonging to the Irish.

Burana, Carmina : See Goliardic Literature.

Burden, The: The burden, or as Puttenham terms it, the love-burden, is a line repeated at intervals so as to constitute a refrain. 


\section{9}

Burlesque : A burlesque is the treatment in literary or dramatic form of dignified and elevated subjects in a ridiculous and comic fashion; it is thus the converse of the mock-heroic, which consists of the treatment of absurdities or trifles in a pompous and elevated style.

Burletta : A comic opera or musical farce.

Buskin: This literally denotes the high-soled boot or $\kappa \circ \theta \circ \rho \nu 0 s$ which Greek tragic actors wore to increase their height and give themselves an awe-inspiring appearance. By metonymy the term was applied to tragedy itself, just as 'sock' or soccus, the low-soled shoe worn by Greek and Roman comedians, is used of comedy. Cf. Milton, Il Penseroso, 'che buskin'd stage '; L'Allegro,' Jonson's learned sock'.

Cacemphaton: An ill-sounding expression (N.E.D.). Cacosyntheton: The lite.ary vice of affected inversion of words.

Cacozelon or Cacozeal: The literary fault of perverse affectation or imitation-' when we affect new words and phrases other than the good speakers and writers in any language or than custom hath allowed' (Puttenham). 'Take heed therefore that Imitation degenerate into Cacozeale' (Bulwer).

Cæsura (lit. 'a cutting'): In classical quantitative verse the failure of the end of the word to coincide with the end of the foot, the end of the word thus cutting the foot in two. This for the sake of rhythm and variety must occur in one of statec feet in each kind of verse. In the hexameter it may be Penthemimeral (q.v.) or Hephthemimeral (q.v.) ; in the iambic trimeter it must occur in either the third or fourth foot. It may be 'masculine', i.e. when the break comes immediately after a long syllable, as 'Sīc tîbí | cūm flūc | tūs \|l'; or feminine, when it occurs after a short syllable, as " $A \nu \delta \rho a$ 


\section{0}

$\mu \breve{o} \iota|\hat{\epsilon} \nu \bar{\nu} \pi \check{\epsilon},| \mu \bar{v} \hat{v} \sigma a||$ '. In modern and accentual verse, the cæsura is little more than the break or check in the rhythm which occurs in nearly all lines, and occasionally, though not necessarily, coincides with a break in sense or grammar.

Calliope: The Muse of epic or heroic poetry ; sometimes referred to in the sense of that class of poetry itself.

Canon: A rule or principle in literature or art to which works must conform and by which they are tested in critical examination. The word is also used to denote the body of authentic writing ; of some author or upon some subject, as the canon of Holy Writ, or the body of authors of established merit in some particular sphere, as the canon of Attic orators.

Cantata: Originally a narrative in verse set to recitative or alternate recitative and air for a single voice accompanied by one or more instruments; now a choral work, differing from an oratorio in being shorter and not necessarily religious, and from an opera both in being shorter and in not being acted.

Cantilène: Originally a secular song (French) as opposed to a 'motet' or piece of church music; thence the term was applied to a species of poetry which constitutes the earliest example of French literature. These were poems, partly lyrical, partly epical; written, it would appear, to be sung to contemporary tunes. The earliest example is the Cantilene de Ste. Eulalie, a poem of twenty-nine verses, of the tenth century. Other examples are the $l i e$ de St. Alexis and the Contes Pieux. It is possible that these cantilènes were the germ of the later chanson de giste.

Canto: The literal meaning of this Italian word is 'a song' or 'a singing'. Hence we get the occasional meaning of a song or ballad, and the almost universal meaning which the word has at the present 
day, viz. one of the divisions of a long poem, such part as a minstrel might sing at one fit. It was used by Dante in this sense in Italian, and by Spenser in English. For an example of the first-mentioned meaning we may quote 'To hear a Canto of Eliza's death' (G. Fletcher).

Canzone: A variety of lyric in Italian literature, somewhat resembling a madrigal, but less strict in style. It resembled the Provençal 'canso', but whereas that was limited in subject to love, the canzone generally dealt with more elevated matter, and had rather the character of an ode. It was written in stanzas of which as a general rule there should not be more than fifteen. The last stanza was followed by a half-stanza like an envoy, termed the 'ripresa' or 'commiato'.

Cape et Epée, Roman de (or Comédie de): A style of romance or comedy which derives its name from a class of Spanish drama of the days of Lope de Vega and Calderon, entitled Comedia de crpa y espada (both names of course meaning 'comedy of sword and cloak'). This Spanish drama was a drama of domestic intrigue, the term merely denoting the rank of the character introduced; the French derivative, however, by a misapprehension of the meaning of the phrase, was applied to comedies and tales full of fighting, adventures, and swashing blows. In this misapprehension the English term 'Sword and Cloak Romances' has followed the French.

Cardinal, The : See Illustrious, The.

Carmina Burana : See Goliardic Literature.

Carol: In its most specific sense a song or hymn of joy sung in celebration of the Nativity at Christmas. More generally it has been used to denote a song or hymn of religious joy, or a joyous strain of any sort. Its derivation is obscure, but those suggested are from corolla, dim. of corona, a circular or ring dance, or 'choraules' (from chorus, a dance), through the 
intermediate meanings of a dance or ring dance accompanied by song, and thence the song acconpaniment itself.

Caroline Poetry: A rough comprehensive term often applied to the poetry of the period from the reign of Charles $\mathrm{i}$ to that of Charles ii inclusive. It is somelimes used merely as a chronological expression, sumetimes with reference to the authors who constitute the latter section of the 'Elizabethan' period. It includes Milton, Herrick, Quarles, Carew, Habington, Waller, Suckling, Lovelace, Cowley, Crashaw, Vaughan, Marvell, Sedley, Rochester, Dorset, etc.

Carolingian Cycle: The cycle of Franco-Teutonic or French romance dealing with the mythical history of Charlemagne and his 'douze pairs' or 'paladins', Koland, Olivier, Turpin, etc., and the traitor Gane. lon. It consists in reality of the grouping together and of accretions to the early episodic chansons de sestc' concerning the exploits of Charlemagne.

Catachresis (lit. 'a misuse'; Greek): The term is employed in etymology to signify the formation of words on a false analogy, such as 'alegar' on the model of 'vinegar', and 'Peterloo' on the mudel of " llaterloo'. It is also used in rhetoric to denote the forcing or straining of words and phrases to an unnatural sense or relation.

\section{Catalectic: See Acatalectic.}

Catharsis: This term, signifying in Greek 'purgation', constitutes the central idea of Aristotle's famous and much-debated dictum concerning the function of tragedy. He says in the Poetics: 'Tragedy, then, is an imitation of an action ... throuch pity and fear effecting the proper purgation of these emotions'. Many theories have been propounded as to the meaning of this formula; some holding the purgation or purification involved to be merely liturgical. The most generally recognized in. 


\section{2}

terpretation is, however, that of Prof. Butcher in ex. pansion of Jacob Bernay's general idea, that the metaphor underlying the expression was medical, and denoted a pathological effect upon the soul, analogous to the effect of medicine upon the body. This analogy was possibly based upon the homœopathic cure of persons seized with religious ecstasy by means of wild and restless music, a process described in the Politics, where it is made clear that the effect of such music is not moral instruction nor relaxation nor resthetic enjoyment, but a physical stimulus providing an outlet for religious fervour. In the same way tragedy excites the emotions of pity and fear, and by the act of excitation affords pleasurable relief. Now pity and fear in real life are by Aristotle reckoned as forms of pain, fear being that species 'arising from an impression of impending evil, which is destructive or painful', while pity is a sort of pain 'at an evident evil of a destructive or painful kind in the case of somebody who does not deserve it, the evil being one which we might expect to happen to ourselves or to some of our friends, and this at a time when it is seen to be near at hand'. By the observation of tragic representation the fear. ful and pitiful is robbed of its personal interest and immediate personal application, and is on the way to being universalized: it is not a sympathetic anxiety for the hero whose suffering is depicted, nor an apprehension for ourselves. Hence the function of tragedy is not merely to provide an outlet for pity and fear, but to provide for them a distinctly æsthetic satisfaction, to purify and clarify them by passing them through the medium of art. Psychologically, indeed, this theory may be considerably more than a metaphor, for deep resthetic absorption in some forms of art, notably music, does frequently effect a sort of complete tranquillity arising out of emotional exhaustion. The recent theory of Prof. Knoke should perhaps be noted. $\mathrm{He}$ proposes to take "purgation" as apart from the words 
'through pity and fear', and to construe the word purgation with reference to what we call a Greek Ending (q.v.), the Greek idea of refusing to conclude a tragedy on a high or tragic note, but rather of ridding the mind of passions by concluding with a few passages of commonplace, which reduces the spectator to his normal emotional level.

Causerie (lit. 'a conversation'; French): In literary matters it denotes a chatty, discursive article upon books and authors and literary matters in genera!.

Cavalier Poets: A term originally applied to Love. lace, but extended to include such Royalist poets as Sucklina, Sedley, Rochester, Dorset, etc., who combined the writing of poetry with the life of a Royalist courtier.

Celtic Revival: A name often given to a movement set on foot towards the end of last century with the object of re-establishing a Celtic literature freed from English influence. Of this movement, which was supported by organizations such as the Irish Literary Society and the Irish Literary. 'Theatre, W. B. Yeats and Fiona Macleod are chief representatives.

Cento: The term derived from the Greek ké $\nu \tau \rho \omega \nu$, a patchwork cloak, used to denote a poem composed of complete lines taken from one or more poets. The practice of this style of composition is of considerable antiquity. We have Homero-centones, or centos of lines from Homer, a Cento Nuptialis by Ausonius, who gives rules for their production, and a Cento Vergilianus by Proba Falonia, a lady who having been converted to Christianity. employed herself in composing an epitome of Biblical history in lines of Virgil. Centos were popular through the Middle Ages. A monk named Metullus composed devotional hymns out of lines chiefly from Horace with the aid of a few from Virgil; Alexander Ross (15001654) produced a Vergilius Evangelizais on the 


\section{5}

lines of the Cento Vergilianus above cited. There is also the Christus Patiens of Gregory Nazianzen; and an anonymous cento of lines from Shakespeare put together to form a birthday ode to that author will be found in Dodsley's Collection.

Chain Verse : See Concatenation.

Changeling, The: The alternative name given by Puttenham in the Art of English Poesy to the figure of $\mathrm{H}$ ypallage (q.v.).

Chanson de Geste: See Geste, Chanson de.

Chant Royal: The term applied in French prosody to a fixed poetical form consisting of five eleven-line stanzas followed by an envoy of five, six, or seven lines. The arrangement of the rhymes is the same throughout the stanzas, and the envoy reproduces the rhyme scheme of the last five, six, or seven lines of the stanzas. The last line of both stanzas and en voy is the same and constitutes a refrain. The chant roy'al should strictly, according to the definition of it given by Théodore de Banville, be addressed only to a divinity, king, or prince, and should celebrate only either divine mysteries or the prowess of roya! heroes; hence its name.

Chap-books: A class of tracts or pamphlets which came into existence early in the seventeenth century. They were hawked about by chapmen or pedlars, and were at one time the only popular literature. They dealt with religion, history, the weather, dreams, ghost stories, etc.

Character sketches: A class of prose works consisting of short studies, each dealing with one particular type or character of mankind. Aristotle's Nicoma. chean Ethics contains some of these in embryo in his definitions of the 'magnificent' man, etc., but the first regular 'characters' were those of Theophrastus, the former's successor at the head of the Lyceum. These short sketches, of which there are about thirty (including such as The Flatterer, The 


\section{6}

Grumbier, The Boaster), gave rise to a considerable amount of similar literature in the seventeenth century : La Bruyère's essays, in France, and Hall's Characterisms of Virtues and l'ices, Overbury's Characters, and Earle's Microcosmografhy', in England. Through the medium of Addison's Sir Roger de Coverley pieces (which are merely character sketches individualized and linked together with an unimportant thread of story) and similar essay's, this class of literature contributed no little to the evolution of the modern novel.

Charientismus or Charientism: Lit. 'gracefulness of style '; bence expression of an unpleasant thing in a pleasant or graceful fashion. Puttenham in his Art of English Poesy' classes it as a species of irony, giving it the alternative title of 'the privy nip'.

Chaucer, School of : Sce School of Chaucer.

Chiasmus: The grammatical term for a crosswise arrangement of two pairs of antitheses, as 'Begot by butchers, but by bishops bred'.

Chœrileum Metrum: A metre, so called because employed by Chœrilus in his satyric dramas, consisting of a dactylic trimeter catalectic in disyllabam followed by a dactylic trimeter catalectic in sylla.

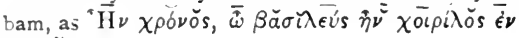

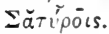

Choliambic: See Scazon.

Choriambus: The name given in Greek prosody to the foot consisting of two short syllables between two long ones, - vu-, as 'illěceěbræ'.

Chorus: The chorus of the fully developed Greek drama had its origin in the earliest germ of that drama itself, the band of worshippers gathered to zether to sing hymns to Dionysus while feigning to represent his satyr attendants. The dithyramb or choral bymn which they chanted was first given an 


\section{7}

artistic form by Arion, who arranged it to be sung at festivals by a trained chorus of fifty persons grouped round the altar, and hence termed a 'cyclic' or circular chorus. It was by the detachment first of the leader or coryphæus of the chorus to narrate the adventures of Dionysus, and secondly of a further member of the chorus to carry on a dialogue with him, that dramatic action proper developed. As, however, tragedy developed separate from the dithyramb, the tragic chorus was reduced to twelve. It is said that such reduction was owing to the fact that each poet produced four plays and the chorus of fifty was apportioned equally to the four, but this cannot be ascertained with certainty. Sophocles raised the number from twelve to fifteen, in which condition it remained. The chorus in satyric drama was composed of the same number of performers as the tragic chorus, but the chorus in comedy appears to have been invariably of twenty-four persons. All choruses, with the exception of the dithyrambic, which, as has been already stated, was circular, were drawn up and 'danced' in strictly rectangular formations, either by 'files' or 'ranks', i.e. (in the case of a tragic chorus) either three abreast and five deep, or five abreast and three deep. As the chorus entered the 'dancing place' or orchestra in front of the stage from the audience's right-hand side in three 'files' and remained substantially in that position throughout the play, the left-hand file was always nearest the audience, and it accordingly contained the pick of the performers. The part of the chorus in the play was to sing the lyric odes or stasima between the episodes or acts, to the accompaniment of 'dancing' or rhythmical evolutions, and occa. sionally to take part in dialogue through their spokesman, the coryphæus. See Tragedy, Comedy, Drama, Trilogy.

Chrestomathy: 'A collection of choice passages from an author or authors, especially one compiled to assist in the acquirement of a language' $(N . E . D$. 


\section{8}

Chronicle History: A species of play (which probably took its rise out of the Morality) dealing with historical events, but without much adherence or respect for the old monkish chronicles. The earliest we have is the Kyng Joinan of Bishop Bale $(1495-1563)$, which is closely connected with the moralities in kind. It was written in rhymed alexandrines, with occasional stanza-forms. Later specimens were the Troublesome Raigne of King John (printed in $159 \mathrm{I}$ ) and the Tragical History of King Leir, upon which Shakespeare based respectively his $K^{i} i n g$ John and Lear. In fact the historical play's of Shakespeare are themselves chronicle histories, and are usually classed together as 'histories', in the technical sense.

Chronogram: An inscription or verse in which the letters used as numerals, when read together and sorted into the order of their importance, give the date of the inscription or event alluded to. The following examples will make it clearer, viz. an epigram upon Queen Elizabeth's death, 'My Day Closed Is In Inmortality', which reads chronogrammatically MDCIII, the year of her death; or this inscription on a medal commemorating a victory of Gustavus Adolphus in 1627: 'ChrIstUs DUX ergo trIUMphans'. Chronograms are of considerable antiquity, and occur both in Greek, Arabic, Persian, and Hebrew, the earliest known being one in a Hebrew MS. of I 208 A.D.

Chronographia: Writing descriptive of times and seasons, as day, night, winter, summer, etc.

Cinquecento: Lit. 'five hundred' (Italian), and by abbreviation the 'fifteen hundreds.' i.e. the six. teenth century of Italian literature and art. It includes Ariosto (1474-1533), Tasso (r544-1595), Rucellai ( $1475-I_{526}$ ), Raphael ( $4_{4} 3_{3}-I_{520}$ ), Titian $(1480-1576)$, Michael Angelo (1474-1564), Machiavelli, Alamanni, Ba!di, etc. It was regarded as a very flourishing period of Italian letters, in con- 
trast to the decadence or extravagance of the Seicento (q.v.). The above-mentioned writers and artists are termed collectively the 'Cinquecentisti'.

Cipher: A secret or disguised manner of writing, whether by characters arbitrarily invented or by an arbitrary use of letters and characters in other than their usual sense, or by any other method intelligible only to those possessing a key; also anything so written.

Classical: The term Classical and its antithesis, Romantic, represent two opposed attitudes in literature and two opposed methods of expression. The 'classical' spirit, which derives its name from the Greeks and Romans, in whom it is most marked, having a noble or lofty thought to express, is content to utter it in clear and simple terms of enuncia. tion, leaving the magnitude and splendour of the bare idea to find its way to the reader's understand. ing. The 'romantic'spirit, on the other hand, is not content with simple enunciation, but strives to convey a feeling or sense of the thought by weaving fancies round it; to effect sympathy with the thought, as it were, and assimilation of its truth by allusion and indirect reference; to produce an atmosphere of the idea itself, in which the reader cannot fail to be involved. A simple instance is the following: Virgil, a classic, wishing to express the pathos of life, gives utterance to tle magnificently simple 'Sunt lachrimæ rerum, et mentem mortaliz tangunt '; Tennyson, on the other hand, a romantic, to express the same thought, omits to state it directly, but gives us the splendid 'Tears, idle tears, I know not what they mean; Tears from the depth', etc., which does succeed in producing what may be called the sympathetic atmosphere. It is precisely by their unerring success in producing this sympathetic atmosphere that the romantic play. wrights of the Elizabethan period are so great. In another aspect of the antithesis 'romantic ' is applied 


\section{0}

to that spirit which seeks and takes delight in the vague and unformed, the never-satisfied aspiration after the unknown and unattainable, while 'clas. sical 'implies an adherence to traditional or exter. nally imposed rules and canons, and acquiescence in things as they are. At bottom, Wordsworth's classification of Poems of Fancy and Poems of Imagination is based upon the first of the above-men. tioned distinctions between respectively Romantic. ism and Classicism.

Clausula : The clausula or close is a term of classical prosody denoting the rhythmic rounding off of a complete verse which proclaims it complete in itself and not merely a series in conjunction with other rhythms. The rhythm contains three such indices of completeness, the beginning (' $\dot{\omega} \theta \mu$ òs $\tilde{\epsilon} \pi a \rho \chi o s)$, the primary rhythm (numerus primarius), and the clausula. These are auxiliary to the three external marks of completion, the Anceps (q.v.), the Hiatus (q.v.), and the end of the word.

Cleomachean Verse: This measure consists of two Ionics a majore catalectic, viz. - - $\smile--\bar{z}$, as

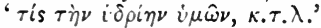

Cliché : Lit. an electrotype or stereotype plate; hence any stereotyped expression, a hackneyed or commonplace piece of phraseology.

Climax: An arrangement of clauses in gradation leading up to and culminating in an effective point, as 'Quod lubet iis, licet; quod licet, possunt; quod possunt, audent . Puttenham's example is :-

' $H$ is virtue made him wise, his wisdom brought him wealth,

His wealth won many friends, his friends made much supply

Of aids in weal and woe, in sickness and in health,

Thus came he from a low, to sit in seat so high'. 
Clio : The Muse of history; often referred to in the specific sense of that class of literature.

Çloka: The ordinary Sanscrit epic metre (quantitative) of sixteen syllables, divided eight and eight, the last four syllables constituting a couple of iambi. In its Vedic form this metre is called Anustubh.

Cockney School: When the establishment of Blackwood's Magazine turned the scale in the controversy anent the Lake School (q.v.) against its detractors, the victorious reinforcements turned their arms against a section of their own adherents. Lockhart, who reverenced the indigenous Lakists, while hating the London supporters of the school, undertook a bitter crusade against the latter, whom he christened with the nickname of the 'Cockney School' in the pages of Blackwoot. 'Its chief Doctor and Pro. fessor is Mr. Leigh Hunt, a man certainly of some talents, of extravagant pretensions both in wit, poetry, and politics, and withal of exquisitely bad taste, and extremely vulgar modes of thinking and manners in all respects'. Other persons included in these denunciations were (besides 'Hunt, the Cockney Homer') 'Hazlitt, the Cockney Aristotle, Haydon, the Cockney Raphiael', Keats, and Lamb. The main stigma of the title was its attribution of bad taste, vulgarity, extravagant pretensions, and, incidentally, low birth. Some of the charges are now immaterial, others rebutted by the verdict of posterity; but it can hardly be denied that in his deportment and writings Leigh Hunt was responsible for some extraordinary lapses from good taste.

Collaborator: One who works in conjunction with another, especially at literary, artistic, or scientific work.

Collate, To: To collate texts or manuscripts is to examine them carefully in comparison with one another with the object of textual emendation or criticism. 


\section{2}

Colophon: A term given to the notice at the end of an old MS. or printed book of the name of the scribe or printer and the date and place of issue, etc. The term is said to have been derived from the town of Colophon, in Asia Minor, the cavalry of which was so excellent that it always decided the issue of any battle in which it was engaged; bence the word came to mean the finishing stroke or fina! flourish.

Comédie Larmoyante: The comédie larmoyantc, or tasedie bourgeoise, as it was also called, was a type of play popularized in France by the dramatist La Chaussée (16́92-1754). It consisted of an action laid in circumstances and surroundings proper to comedy, but with an element of romance, and a large admixture of pathos due to the representation of virtue in distress. A typical piece of this class is the above-mentioned author's La Gouvernante (1747). The style received the condemnation of Voltaire.

\section{Comedy : Sce Tragedy.}

Commedia dell' Arte: A form of Italian comedy which has descended direct from the Atellan farces (q.v.). As in those farces, the characters were stock types: Pulcinella, the foolish country lad, who always gets into trouble and is punished for others' mischief, answering to the Oscan Maccus; Pantalone, the ridiculous old miser who is always falling in love and being swindled by women and others, answering to Pappus; the Captain, a swaggering Braggadochio who is up to any dirty work for a reward, answering to Bucco; and the Doctor, a quack who gets money out of Pantalone, answering to the Oscan Dossennus, and others. The commedix aell arte was more. over mainly the improvization of its actors, and while we may presume there were more or less stock situations, the dialogue and incidents were constantly shifting. It became popular in the fifteenth century, and several Italian companies 


\section{3}

toured the Continent, notably the 'Gelosi', invited to France by Henri iii in 1576 , and the 'Comici Fedeli', who succeeded the former in 16 r4. In the seventeenth century it reached perhaps its highest point of development, representing in the poor condition of written comedy which then prevailed in Italy the main example of the art in that country.

\section{Commiato: See Canzone.}

Commoratio: The rhetorical figure in which the speaker clings to an important and established point to the neglect of less safe ground.

Common Halleluiah Metre: See Common Long Metre.

Common Long Metre: The term given in psalmody to a six-line stanza of which the first four lines consist alternately of eight and six syllables each, while the last two are both eight.syllabled (8.6.8.6.8.8). It is also called 'Common Halleluiah Metre'.

Common Metre or Measure: The term given in psalmody to a stanza of four lines of iambic rhythm and eight and six syllables alternately (3.6.8.6.). Double Common Metre is a similar stanza of eight lines.

Common Particular Metre: The term given in psalmody to a stanza of six lines, all of which, with the exception of the third and sixth, which contain six syllables, contain eight syllables (8.8.6.8.8.6).

Commus: A lyrical dirge in Greek tragedy performed by an actor on the stage and an individual member of the chorus in duet.

Comparative Literature: The study of literalure with particular reference to the influence exerted by the literature of one country or language upon that of another.

Concatenation or Chain Verse : Verse in which each line hegins with the last words of the previous line. 


\section{4}

It is said to have been invented by the French poet Lasphrise, but there are many examples in English. Puttenham in the Art of English Poesy calls it 'a heel.treading kind of verse'. C Cf.-

'The longer life, the more offence ;

The more offence, the greater pain;

The greater pain, the less defence;

The less defence, the lesser gain;

The loss of gain long ill doth try :

Wherefore come, Death, and let me die'.

Körner's Sưord Song has been said to make use of concatenation, but what is found there is in strictness the French $R$ ime Concatenée (q.v.).

Conceit : A quaint or odd thought, particularly such a thought or turn of expression intended to be striking and poetical, but in reality far-fetched, insipid, or pedantic. The term was derived from the Italian concetti, which, like their English namesakes, became the prevalent fashion in Euro. pean literature of the latter part of the sixteenth and earlier part of the seventeenth century, and contributed materially to Euphuism, Gongorism, Marinism, etc.

Conceptistos: See Gongorism.

Conceptismo: The practice of the Conceptistos, for whom see Gongorism.

Conditional Sentence : The term given to a sentence which sets forth the consequence, possible, probable, past, present, or future, of a certain assumption or hypothesis, as 'if this is so, that will be so'. By its nature, therefore, the conditional sentence is divisible into two main members: one, termed the Protasis, embodying the condition or hypoth. esis; and the other termed the Apodosis, embodying the consequence.

Contes Pieux: A body of early French poems inspired by religious feeling telling of miracles obtained by the intercession of the Virgin or the 


\section{5}

saints. Some are by a Benedictine monk, Gautier de Coinci (II77-1236).

Coronach: 'A funeral song or lamentation in the Highlands of Scotland and in Ireland; a dirge (N.E. D.): the title of a poem by Sir Walter Scott. Coryphæus: The best and most important man in the Greek chorus (q.v.). In the formation of the chorus 'by ranks' i.e. (in the case of the tragic chorus of fifteen) five abreast and three deep, the coryphæus or leader of the chorus occupied the central position of the file next to and facing the audience. This file was composed of the pick of the whole, and the coryphrus set the time, gave the note, and acted in other ways as captain. When the chorus took a part in dialogue, he was the spokesman, and his gestures were supposed to be a conspicuous feature of the performance. The word means 'chief man', and from it is derived the French coryphée, meaning a dancer.

Cosmic Drama: A term which has been given to the development of the mystery presented by the English Corpus Christi plays, in which the various subjects have come to be grouped in a huge cycle illustrative of the history of the universe from the Creation, through the Annunciation, Nativity, Passion, Resurrection, Ascension, Antichrist, etc., to the Advent of Christ in the Last Judgment.

Counterfeit Action, The: Puttenham's alternative term for Pragmatographia (q.v.).

Counterfeit Place, The: Puttenham's alternative term for Topographia (q.v.).

Counterfeit Time, The: Puttenham's alternative term for Chronographia (q.v.).

Couple: The technical name for a stanza of a Lai (q.v.).

Couple-Clause, The : The alternative title given by Puttenham in his Art of English Poesy to the figure of Polysyndeton (q.v.). 
Couplet: A rhymed distich or pair of lines.

Crasis : A feature of Greek prosody consisting of the contraction of two vowel-sounds in hiatus into the mean vowel-sound resulting from such contraction. The effect also is that the two words to each of which the vowel-sounds respectively belong coxlesce into one word, as $\kappa \dot{a} \iota \dot{\epsilon} \mu \epsilon$, which by crasis becomes

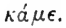

Cretic: See Amphimacer.

Criticism of Life: A part of Matthew Arnold's famous definition of poetry as 'acriticism of life under the conditions fixed for such criticism by the laws of poetic truth and poetic beauty'. 'Criticism of Life' is further leined as 'the application of ideas to life'. The definition lays stress upon the 'hizh seriousness' of the best puetry; its moral calibre as dealing with the great facts of life.

Cross Poem : A variety of Figurate or Emblem. atical Poem (q.v.).

Cryptogram : Anything written in cypher or in such form or order that a key is required to make it intelligible.

Culteranismo: The extravagant affected style of the Cultoristos. Sce Gongorism.

Cultismo: The same as the preceding.

Cultoristos : See Gongorism.

Curial, The : See Illustrious, The.

Curry-favell, The: 'The Curry-favell' or 'the Soother', are the alternative titles given to the figure of Paradiastole (q.v.) by Puttenham in his Art of English Poesy.

Curtain Raiser: A curtain raiser or lever du rideau is a short one-act play presented before the dramatic piece de résistance of the performance; it is thus said to raise the curtain on the play which follows it. There are no special rules for the manufacture 
of this kind other than those dictated by the circum. stances; it must, of course, be short and subordin. ated to the main play in interest and merit It is usually a pleasant or amusing trifle.

Cycle: A series of interconnected pieces complete in themselves. Thus we have sonnet-cycles, series of sonnets strung together by the general sense; cyles of romances, such as the Arthurian (q.v.) or Caro. lingian (q.v.), composed of several romances all dealing with some one hero; and epic cycles, series of epics each dealing with consecutive episodes of one legend. See Cyclic Poets.

Cyclic Poets: Besides the incidents narrated in the Iliad and Odyssey, there was a great store of legend concerning the campaign against Troy. At times between, roughly speaking, $77^{5}$ and 530 B.c. this material was worked up by epic poets of the Ionian school into a series of epics which together with the Iliad and Odyssey constituted a sort of continuous history of the Troy legend. Such a body of epics chronologically arranged was termed an Epic Cycle, and the poets who composed the supplementary epics were termed Cyclic Poets. The Trojan Cycle, we are informed by Proclus (r 4 O A.D.), included the following epics: the Cypria, by Stasinus of Cyprus, covering the preparations for the war and the first nine years of the siege, leading up to the Iliad; the AEthiopeia, by Arctinus of Miletus, which followed the Iliad and related the history of Memnon; the Sack of Troy, by the same writer in continuation of the last; the Little Iliad, by Lesches of Mitylene, which continued the Iliad to the fall of Troy, with especial attention to Ajax and Philoctetes; the Homeward Voyages, by Agias of Trœzen, which filled in the ten years between the Iliad and Odyssey; and the Telegoneia, by Eugame mon of Cyrene (c. 586 B.c.), relating the story of Telegonus. There was also, however, a Theban Cycle, which included the Thebais and the Epigoni, 
and a cycle concerning Heracles, of which the Taking of Oechalia was a single unit. The term Epic Cycle also denoted a cycle the units of whicb were not single epics, but subordinate cycles such as the Trojan and Theban above cited.

Dactyl: The metrical foot consisting of a long syllable followed by two short ones $(-\smile \checkmark)$. The word is derived from the Greek $\delta a ́ k \tau u \lambda o s$, a finger, on the analogy of its one long and wo shorter joints.

\section{Dante, School of: See School of Dante.}

Débat: Sic Estrif.

Décadents (decadent): See Symbolistes.

Decastich: A short poem or epigram of ten lines.

Decasyllables: Lines of ten syllables.

Default, The Figure of: The alternative term given by Puttenham in his Art of English Poesy to the figure of 'Ellipse' (q.v.).

Della Crusca School, Della Cruscans: The name given to a group of English poetasters who founded a sort of salon at Florence in 1794 . This coterie, chief among which were Robert Merry, himself a member of the Italian Accademia Della Crusca, Mrs. Piozzi, William Parsons, and Bertie Greathead, styled themselves the 'Oziosi' or 'Leisured', and wrote each other complimentary verses and verse exercises which were preserved in albums. One of these collections, named The Arno Miscillany, was privately printed, and followed in $17 \sum_{5}$ by the publication of a second, The Florence Miscellany. Though the verses were of the poorest class of insipid trash and mawkish sentimentality, they were received with acclamation, in the absence, at this period, of any contemporary poetry of merit. The society. soon after dissolved, but Merry, return. ing to England, continued his effusions in the pages 
of The Horld over the signature Della Crusca. A long verse correspondence ensued in The World between Della Crusca and Hannah Cowley, the author of The Belle's Stratarem, under the pseudonym of Anna Matilda. Della Crusca became first a fashion, then a furore, and initators arose on every side. Collections of their verse were published, entitled respectively The Poetry of the World and The British Albunn; but at the height of the mania appeared The Baviad, by Gifford, then unknown, followed by The Marviad, the healthy satire of which checked, if it did not put an end to, the absurd follies of the craze. At any rate, a saner standard of criticism thereafter prevailed, and the Della Cruscan inanities lingered on to a natural death in well-merited obscurity.

Dénoument: Sce Lysis.

\section{Descort: See Lai.}

Desis : See Lysis.

Deus ex Machina: The machina (Greek, $\mu \eta \chi \alpha \nu \eta$ ) or machine was an appliance of the Greek stage, consisting of a crane with a pulley attachment for raising or lowering, situated at the left or western corner of the stage at the top of the back wall. Its object was the lowering or raising of characters such as gods or heroes when their appearance or disappearance was required, or when it was necessary to represent a flight in the air. Thus it was by this means that Euripides represented Bellerophon riding off upon his winged steed Pegasus, or that Try. gæus rode upon a beetle in the Pax of Aristophanes. The use, however, which has won the phrase deus ex machina its proverbial sense was the production of a god to untie the knots at the conclusion of a play, and to straighten everything out by supernatural interposition. The god so descending by means of this contrivance was termed deus ex machina, or the god from the machine, and the phrase was 
applied to the practice of solving any deadlock to which the plot had worked by supernaturai means. That practice is of course faulty, and is reprobated by Aristotle as such, for the incidents of a plot should work out its own solution by the natural sequence of events without recourse to violent inter. ference on the part of Heaven.

Deuteragonist: Jesides the chorus (q.v.), the max. imum number of actors permitted upon the Greek stage was three. Tradition has it that before the time of .Eschylus there was only one actor, and that the addition by him of a second made it possible for a dramatic action to be represented. This second actor was called the Deuteragonist.

Of the characters of the piece he took those of secondary importance, between the leading parts of the Protagonist (q.v.) and the parts played by the Tritagonist or third actor (q.v.), each actor, of course, having to play several parts by 'doubling'. The deuteragonist and tritagonist were strictly subordinated to the protagonist, and not allowed to put him in the shade. They were themselves appointed by him.

Dialect Novel: A novel dealing with provincial life, and reproducing in a background of local scenery and customs the natives of the locality speaking their own variety of dialect.

Diallage: The rhetorical figure of thought consisting of the employment of several arguments for the establishment of a single point. This is termed in Latin, Consummatio.

Dialysis: A term used indifferently to denote either Diæresis or Asyndeton (q.v.).

Diastole: The grammatical term denoting the licence of lengthening a short syllable; so opposed to Systole (q.v.).

Diatessaron: A harmony of the four Gospels. The 
earliest, now lost, was written by Tatian in the second century A.D.

Didactic Poetry: Poetry which acts as a vehicle for the expression of the facts or principles of some art or science, and at the same time surrounds them with beauties of imagination or sentiment. The earliest extant didactic poem is Hesiod's Works and Days (c. 850-800), but it should be remembered that Hesiod employed verse as the medium of his communications because there was no other. prose not at that time having developed as a literary form. His poem was not therefore a conscious literary effort to be judged on the same footing as Virgil's Georgics, for examp!e, but rather more resembles in aim Tusser's Five Hundred Points of Good Husbandry, which was written as an agricultural treatise and couched in verse possibly to assist the memory. The danger of didactic poetry is that the teaching, or indeed the subject, niay be trivia and commonplace, and lack the power of arousing emotion which alone can justify its poetic dress. Virgil's Georgics bad an underlying purpose and vigour which defeated the possibility of bathos. His work was less a handbook of agriculture than a glorification of nature and the homely life of the country, with the aim of restoring the old simplicity of morals and checking national decay.

Diiambus: The double iambus, a metrical foot con. sisting of two iambi $(u-v-)$.

Dimeter: In Greek prosody the trochee, iambus, and anapxst are not scanned separately in single feet, but in pairs of feet or dipodes, each of which is called a 'metre'. A dimeter, therefore, is a line consisting of two such metres; as, e.g., a trochaic dimeter :- U$\checkmark 1-u-u$. The reason for the above-mentioned practice of grouping these feet is that in a succession they will not receive an accent apiece; i.e. in the reading of a series of trochees, the voice will tend to stress the long syllable of every other foot, 
the intermediate long going almost entirely un. stressed. It will be found difficult and at any rate unmusical to recite a series of trochees with a stress on every long.

Dirge: A funeral song or chant, such as Shakespeare's 'Full fathom five', from the 'Tempest, and Webster's 'Call for the robin-redbreast and the wren', from the Duchess of Malfy.

Disabler, The: The alternative title given by Putrenham in his Art of English Poesy to the figure of Meiosis (q.v.).

Disguising or Disguise : A term for a simple form of Masque (q.v.), differing only in that the performers did not wear masks. Ien Jonson in the Masque of Augurs definitely identifies it with the masque:-

'Votch. Be not so musty, sir; our desire is only to know whether the King's Majesty and the Court expect any Disguise here to-night.

"Groom. Disguise! What mean you by that?

'Notch. Disguise was the old English word for a masque, sir, before you were an implement belonging to the Revels.

'Groom. There is no such word in the office now, I assure you, sir; I have served here, man and boy, apprenticeship or twain, and I should know. But by whatsoever you call it here will be a Masque, and shall be a Mlasque, when you and the rest of your comrogues shall sit disguised in the stocks'.

Dispondeus: The double spondee, a metrical foot composed of two spondees (-- - ).

\section{Disputoison: See Estrif.}

Distich : an epigram or poem of two lines only (Greek, $\delta i \sigma \tau(\chi 0 \nu)$.

Dit: The name given to a species of short poem dealing with commonplace subjects of everyday life which had a considerable vogue in France in the IIiddle Ages. The earliest specimens dealt exclu. 
sively with matters peculiar to a trade or calling as that of a blacksmith or innkeeper. In the fourteenth century, however, they took on a tendency to moralize, as, e.g., the Dits des Femmes, des Quatresaurs, etc. Some of the earlier ones were descriptive, as the Dits des Rues de Paris; while in the middle of the thirteenth century the term was generally applied to any piece of satirical or didactic verse.

Dithyramb: Dithyrambic poetry was a species of Dorian lyric poetry, and is supposed to have been invented by Arion (620 B.C.). 'It was afterwards cultivated in Athens so as to form an independent style. A bacchanal enthusiasm is the prominent characteristic of this kind, and the form corresponds to it. The metre, especially after Timotheus (B.C. 400), consisted of ever-varying rhythms, full of bold measures and rapid transitions. The music too, in the Phrygian mode, with wind instruments, and the dance performed by cyclic choruses, had a wild, overpowering character'. See Chorus.

Ditrochæus: The double trochee, a metrical foot consisting of two trochees $(-\smile-\checkmark)$.

Dittography: The name given to a usual class of error in manuscript transcription, consisting of the repetition of a word which occurs a few lines previous in the text by reason of its having caught the copy. ist's eye.

Dittology: A double reading or interpretation of a text.

Dizain: The term in French prosody for a ten-lined stanza. Written in octo- or decasyllabic lines it is used by itself as a complete poem of fixed form.

Dochmius: The metrical foot in classical prosody as follows: $\smile--\smile-$.

Doctrinaire: One who wishes or attempts to apply general principles and theories, however excellent in the abstract, to the relations of actual life without 


\section{4}

making allowance for particular circumstances. The word is also applied adjectivally to the writings or opinions of such people.

Dodecasyllables: Lines of twelve syllables; with six beats in each line they are Alexandrines (q.v.).

Donne, School of: See School of Donne.

Double Acrostic: See Acrostic.

Double Common Metre: Sec Common Metre.

Double Supply, The : The alternative title bestowed by Puttenham in the Art of English Pocsy upon the figure of Syllepsis (q.v.).

Double Villanelle: A poem of fixed form constructed like the Villanelle (q.v.), but with six-ine stanzas in place of the tercets, and an eight-line stanza in place of the final quatrain.

Doublets: The term applied to a pair of words of the same language, which, though differing from each other in form and perhaps meaning, have nevertheiess been derived from the same root by different pro. cesses of development, as 'fashion' and 'faction', bo:h frum the Latin fictio.

Doubtful, The: The name given by Puttenham in his Ant of English Poesy to the rhetorical figure of Aporia (q.v.).

Drama: The species of literature consisting of the actual representation of something being done, or 'acted', befure the eyes of the spectators, as opposed to what is narrated. The word itself (Greek) means 'something done or performed', in fact 'action' in our modern sense. All that we know about the origin of drama in particular instances warrants the general assertion that it arose in some way out of religion or religious festivities. Greek drama, the earliest and one of the most perfect forms, arose out of the chorus of satyrs gathering round the altar of Dionysus to celebrate the exploits of the sod in hymns, which expanded 
into combined narrative and hymn, and thence to dialogue (see Tragedy). Drama had a different origin, however, in Europe towards the end of the Middle Ages, but its origin was none the less connected with religion, as it sprung out of the liturgical ritual of the Church, the semi-dramatic acts and processions of priests in the celebration of Mass, and the antiphonal nature of parts of the service, which afforded an easy transition to dialogue. Hence sprung the Mysteries (q.v.) performed at the great seasons of the Church as an act of worship; at first outside the doors of the holy edifice. Thereupon followed Moralities, and later the regular drama in England, aithough 'autos'. the liturgical drama in Spain, had already received a considerable measure of artistic perfection. The drama of the sixteenth and seventeenth centuries in Europe was doubtl ss considerably affected ty the practice of Greek dramatists (more especially through the Latin imitations of Greek comedy by Plautus and Terence, and of Greek tragedy by Seneca) and the precept of Aristotle-the latter, however, generally misinterpreted; but this second rise of drama had a separate descent, and an origin independent of the classics.

Dramatic Ciairvoyance: A term to which J.A. Symonds gave currency in his Shatstere's Predecessors, signifying the peculiar faculty possessed by the great romantic dramatists of piercing to the springs of human passions and motives with no apparent or possible medium; 'an insight into things beyond their own experience'; a kind of untaught and intuitive perception and sympathy with human emotions.

Dramatic Poem: The term usually applied to a poem which, though cast in dramatic form, is either not intended or wholly unsuited for actual dramatic representation; a play 'for the closet', as it is sometimes called; intended to he read, not acted. 


\section{Among drama: poems we may class the plays of Sheiey and iyron.}

Dramatis Personz: 'The charazters of the play' (Latin), the stereotyped title to the cisual lis: of charaters which heacis a piayilil or precedes a published piay. Iit. firsoniz means a mask; and the phrase has sirvived from the days of Latin drama, whon, i: initation of Gree: nodels, every a tor wore a mask which by a we...recoznized convention informed the audience of the character be representei.

Ecbasis: 'Ther' =turizal term for an arzument drawn from the reiati, of cause and elfect: an arzument for or againsi it troposal from a constleration of pruable cutatinences.

Ecbole: Ihe rh-: ical term fur a dirression in which a person is inctuctued speaking his own words; generally a dizession.

Echo Verses: lerses constructed in such a fashion that the last syiables or syliable in a line are repeated by way of reply or refrain, as it were, by an echo, as. for exan.?!), the lines of Dean Swift, A Gintle Ecit. i ii "Man:-

"Shepheri. Echo, I ween, will in the woods reply And quaintly answer questions. Sha.l I try?

\section{'Echo. Try', etc.}

They are of consiterable antiquity. It is said that the lost tragedy of Euripides, the Androntitiz, con. tained something of the sort, and there are certainly specimens in the Greek Antholozy, while Martial refers to the practice. Coming to more modern times, we find echo verses in France from the pens of famous writers, from Du Bellay to Victor Hugo; in England, ridiculed by Futler in Huitioras, written by George Herbert, and both written and ridiculed by Addison. The French term is $R$ mes en Echo (q.v.). 
Eclecticism: The system in any sphere, literary or otherwise, of borrowing doctrines and principles from various sources; of accepting what is best in diverse schools or movements.

Eclipsis : The omission of words needed for the full comprehension of the sense. The term is sometimes applied to the dash or line which shows that some part of a passage quoted is left out. In the first meaning it practically coincides with Ellipse (q.v.).

Eclogue: Strictly, a selectlon; but because Virgil's Bucolics were called Ecloga, viz. selected pas. torals, the word took on the meaning of a short pastoral poem, especially in tialogue (sce Pastoral and Amobaan Ode). Hence it has been used erroneously in the sense of 'a conversation'. The spelling 'raglogue' is due to the false derivation of the word from the Greek $a$ ' $\xi$, a goat.

Ecphonesis: An exclamation or exclamatory phrase: 'it utters our mind by all stuch words as do shew any extreme passion' (Puttenham).

Ectasis: The term applied to the lengthening of a short syllable.

Elegy : From the Greek $\iota^{\prime} \lambda \epsilon \gamma / 0$, which is not Greek by origin, but the 'Greek form of a name given by the Carians and Lydians of Asia Minor to a mourn. ful song accompanied by the flute : It is possibly from the connection of the word with such a song that we get the term Elegiacs (q.v.). Coleridge says: 'Elegy is the form of poetry natural to the reflective mind'. This was certainly the content of elegy with the Greeks, at whose hands its general characteristics were: (I) the expression of the poet's own reflections; (2) an earnest or animated utter. ance stopping short of passion. More particularly, however, the word elegy has come in English to denote a song of mourning for some dead friend.

Elegiac Verse: This metre consists of a series of 
distichs, the first line of which is a bexameter, the second a pentameter. It was used in Latin by Ovid, Tibullus, Propertius, Catullus, etc. It is by its nature and cadence most suited to mournful solitoquies and complaints, and derives its name from this characteristic; it is for the same reason excluded from drama, being used only once in Euripides' Andromeia, where the subject seems to require it.

Elision: In classical prosody, to avoid hiatus, viz. the juxtaposition of two vowel-sounds, one at the end of $a$ word and another at the beginning of the following word, the former is elided, i.e. cut out, and the result of the process is termed elision. The cidei syliable, as in 'Hae tib[i] erunt artes', dis. arpears entireiy as far as scansion is concerned, being disregarded by the metre; in actual recitation, how zier, it is probable that Synaresis (q.v) took place and that the elided syllab!e was not cut out a'toge:cer, but slurred or partially pronounced. A variety af elision is Prodelision ( $\mathrm{q} \cdot \mathrm{v})$.

Elizabethin: A term loosely applied to denote the period of inglish literature between and including Sackville $(\mathrm{I}=03$ ), with his mere promise of emancipation for Eng.ish poetry, and the closing days of the romantic drama in shirley (d. I666). It is, of course, a misnomer, and apt to be misleading in that it contains sevcral stages, while it also com. prises authors who have little in common. It was, however, a period of intense vigour and fertility, and the term is convenient as covering this age of exuberance beginning with the bare promise down to the close of the romantic inspiration and its suc. cession by the Augustans.

Ellipse: The omission of one or more words strictly necessary to the grammatical construction or full cumprehension of the sense; the term also denotes the dash or line indicating the omission of letters, as 'the k-ng, for 'the king'. 
Emblematical, Figurate, or Shaped Poems : Poems constructed of lines of such differing length and arranged in such a way that when printed or written they exhibit a shape bearing reference to their sub. ject. This abominable form of the torture of literature was, according to tradition, invented by one Simmias of Rhodes (c. B.C. 324 ), who left three poems, respectively entitled and in the appropriate shapes of The Winss, The Egg, and The Hatchet. Verses of this sort were in vogue in the best period of Greek poetry, and in Latin of the later Empire and Middie Ages; in the sixteenth and seventeenth centuries they became popular in Europe. Of English examples we have The Altar and Easter Wings by George Herbert; a cross by Herrick, another anonymous cross, and a most elaborate Crucifixion, also anonymous; whilst from more modern sources we have violins, wine-glasses, etc. Emblematical verses have been deservedly repro. bated by many, including Samuel Butler and Ben Jonson, who ridicules the pattern-cutting poets who fashioned 'A pair of scissors and a comb in verse'. They are still, it is said, regarded with approval in the East, in China and Japan, to the ingenious spirit of which countries they are perhaps better suited.

Emblems: This term, as used in connection with the book of that name by Francis Quarles ( $1592-1644$ ), refers merely to the designs with which it is illustrated, the plates of which, together with the general plan of the work, were possibly borrowed from the Pia Desideria of Hermann Hugo, a Brussels Jesuit. It has, therefore, no connection with Emblematical Poems (q.v.).

Enallage: The interchange of one word for another; either one part of speech for another, one case for anotner, or one number for another. Cf. examples of the first two varieties: 'aliena cras'; 'seu Jane libentius audis'. 
Enclosed Rhymes: Rhymes following the formula $a b b a$, as, e.g., in the stanza-form of Tennyson's In Aflloriam. The French term is Rimes Emlirassés (q.v.).

Encomia: According to Puttenham, a variety of 'poetical rejoicings'; those that were to honour the persons of great princes, or to solemnize the pomps of any instalment, were called Encomia; we may call them 'carols of honour'. The name is given to a class of Pindar's odes of the nature above desaibed.

Encyclopédistes, Les: In 1 745 Diderot was asked to sive his assistance in the production of a Frencb transiation of Chambirs's Encyclopadia. He under. took the task, but in the course of his labours became dissatisfied with the work, and planned 2 production on a far larger scale, which he expounded in his Prospectus of 1750 . In the actual editing of the stupendous work, the Grande Encyclopédie, as it has been termed, he associated with himself D'Alembert ; and many illustrious writers, including Voltaire, Montesquieu, Rousseau, Buffon, Turgot, Quesnay, etc., were secured for contributions. The plan excited, however, great jealousy and enmity, both the Jesuits and Jansenists having been alien. ated by the rejection of their services, and one by one the supporters of Diderot defected in the storms which raged round the scheme. In 759 the privilege of publication was revoled, but the decree was not enforced; and in spite of frequent checks and hin. drances, Diderot, who was possessed of extraordinary energy and versatility, managed to get the work accomplished in twenty eight folio volumes by 1772 . - When all was finished the scientific movement of the century was methodised and popularised; a barrier against the invasion of the past was erected; the rationalist philosophy, with all its truths and all its errors, its knowledge, and its ignorance, had obtained its Summa'. Those who took part in or assisted 
the Encyclopedie in controversy are accordingly termed Les Encyclopéclistes. Its influence is said to have contributed considerably to the causes of the French Revolution.

End-stopped: As applied to blank-verse, those lines are end-stopped in which the end of the line coin. cides with the end of the clause, there being no enjambement (q.v.) or running over into the next line. As applied to the heroic couplet, it denotes that the sense or grammatical clause is complete and locked up within the couplet, and does not overflow.

Enjambement: When in poetry the end of the grammatical clause fails to coincide with the end of the verse or line, and runs on to the next line, this condition of affairs is called enjambement, as, e.g. -

'We are such stuff

As dreams are made of, and our little life

Is rounded with a sleep'.

It is a necessary condition of the freer and more natural flow of language which dramatic verse requires, and was extensively employed by the great Elizabethan playwrights in their maturity.

Enlightenment : See Aufklärung.

Enterludes: See Interludes.

Enthymeme: The form of the syllogism adapted to rhetoric, viz. one based on merely probable grounds; a rhetorical and not a demonstrative or logical proof. The term is, however, used by Cicero to denote a striking antithesis concluding a rhetorical pericd; and owing to a misapprehension of the nature of its variation from the full or perfect syllogism, it has been thought to be a syllogism in which one premiss is suppressed.

Entremeses: Burlesque interludes introduced in Spanish comedy between the Loas or preludes and the play proper. When interspersed with music and dancing these interludes were called Saynetes. 
Entremeses appear to have originated in the first half of the sixteenth century.

Entremets: An early form of French dramatic performance consisting of a succession of allegorical representations. Sometimes they were nothing more than disjointed entertainments of many kinds-min. strelsy, dancing, recitations-all accompanied by music.

Envoy: See Ballade.

Epanadiplosis: The repetition of the first word of a sentence at its end, as 'O Sophonisba! Sophon. isba O :

Epanalepsis: The rhetorical figure consisting of the repetition of a word or sentence after intervening matter.

Epanaphora = Anaphora (q.v.).

Epanastrophe: The rhetorical figure consisting of the repetition of the end word of one sentence as the first of the next sentence.

Epanodos. A rhetorical term denoting: (r) the repetition of a clause with its parts in inverted order, and (2) the return to subjects already touched upon collectively for separate and detailed treatment.

Epanorthosis: The term given in rhetoric to the correction by a speaker of his own words with the ob. ject of making a more effective or emphatic point.

Epenthesis: See Metaplasm.

Epic: A poem of a semi-dramatic character dealing by means of narration with a series of beroic achievements under supernatural guidance as a poetic whole, with proper subordination of parts to a certral idea. It proceeds by narration, and is therefore less dramatic than the drama, inasmuch as the personality of the narrator is felt, and the sense of externality in the scenes and actions depicted is not complete for that reason. Epic, however, as Aris. 
totle points out, partakes of the character of drama, but differs from it in point of embracing a greater area, and being composed of many incidents, each of which would serve as a dramatic plot, in being a narration of the past instead of a representation of the present, and in being able to relate events simul. taneously occurring in different places, which drama cannot do. There are two main types of epic, the popular or national epic, and the artificial or literary epic. The former class includes such as the Iliad and Odyssey in Greek, the Mahabharata and Ramayana in Sanskrit, the Shahnameh in Persian, the Nibelungen-lied in German, etc. The latter class includes such epics as Virgil's EE neid, Ariosto's Orlando Furioso, Tasso's Gerusalemme Liberata, Camõens' Lusiad, Milton's Paradise Lost, etc.

Epic Cycle: See Cyclic Poets.

Epicedium, Epicede, Epicedion, or rarely Epice. dian: A funeral ode; 'a copy of verses in praise of the dead ' (Phillips).

Épiceries: Lit. 'groceries'(French); the contemptuous term bestowed by members of the Pléiade (q.v.) upon the verses and verse-forms (such as the ballade, rondeau, etc.), to which the then obsolescent schoof of Marot clung, and which the pindariseurs wished to supersede.

Epichireme: The rhetorical and logical term for an attempted proof based on premises lacking establish. ment, but the assumption of which is justified by a reason given.

Epigram: Lit. 'an inscription'; and this was the meaning originally borne by the word in Greek litera. ture, viz. a short inscription of a few lines suitable for an altar, monument, tomb, dedication, or thanksgiving, not necessarily with any point or 'sting in its tail'. This characteristic evolved haturally from the circumstance that something had to be said in a short space, which obviously made neatness and 
poit: a destrable object. The English conception of an epigram, however, and the English practice of its composition, was not directly derived from the Greek, but from Latin authors, both directly, and indirect'y through French channels; especially from Nartial, who was a great favourite with the Eliza. ethans.

Epileny: A song of the vintage, a song in praise of wine, a drinking song: a rare term, found in Motleux' translation of Rabelais.

Epilogue: The conclusion, peroration of a speech; more frequently in English drama, a speech or short poem addressed to the spectators by one of the actors at the close of a play.

Epimone: The Greek term for a refrain; a verse recurring at regular intervals; the Latin z'ersus inicrataris.

Epiphonema: A rhetorical term for 'an exclamatory sentence or striking reflection which sums up or con: cludes a discourse or a passage in the discourse" (.T.E. C.).

Epiplexis: The rhetorical term for persuasive upLraiding.

Epiploce: The figure of rhetoric consisting of the a - umulation of one aggravation or striking circum. stance upon another in due gradation.

Episode : In Greek drama the 'episode ' corresponded to the modern 'act', denoting that portion which came between two choral odes. It soon came to have the meaning, however, of something incidental to the main plot, a digression not causally connected with the proper developmert of the story. In this sense an episodic plot is condemned by Aristotle (Poetics), who lays down the principle that the progress of the plot should be the result of the inter. action of the component characters and circum. stances, and that the introduction of matter extra. 


\section{5}

neous and not contributing to such progress is undesirable.

Epistolary Style: A style suitable to letters; what has otherwise been termed a familiar style, one rather freer and looser than is usually permitted in set and formal prose. The epistolary style of novelwriting is, however, a different matter, and denotes that, introduced by Richardson, of telling the story by means of a series of letters passing between the various characters.

Epistrophe: The rhetorical figure of the repetition of the same word at the end of successive clauses or sentences: "We are born to sorrow, pass our time in sorrow, end our days in sorrow'.

Epitaph : A short composition either in prose or verse, nominally for the tomb of a deceased person, and generally setting forth his or her excellences and the regrets of the bereaved. Many beautiful verse epitaphs have been written, particularly in the seventeenth century of English literature, by Wotton, Herrick, etc.

Epithalamium : A marriage hymn, a form of compo. sition of great antiquity. In ancient Greece and India it was a part of solemn ritual chanted by the priest; but by the time represented in the Iliad it had become secularized, and is referred to as a hymn of congratulation suing as the bride was escorted to her future home. There are several examples in Greek poetry: there is notably the fine epithalamium upon the Marriage of Menelaus and Helen, the eighteenth idyll of Theocritus, and we are told by the scholiast that this was imitated from an epithalamium by Stesichorus (620 B.C.). In Latin poetry there are examples in Catullus, lxi and lxii, and elsewhere. This subject of composition became very popular in England in the sixteenth and seven. teenth centuries, when weddings were regularly celebrated by festivities which frequently included a masque or other literary display. Puttenham, in 


\section{6}

the Art of Englis/2 Poesy, classes the epithalamium among songs written on occasions of rejoicing, and says: "This was done in ballad wise... and was sung very sweetly by musicians at the chamber-door of the Bridegroom and Bride, and they were called Epithalamies, as much as to say as ballads at the bridal couch. For such as were sung at the board at dinner or supper were other Musics, and not properly Epithalamies'. Further, in the notes to his own Hymenai, Ben Jonson lays down definite canons for this style of composition, modelled, as he expressly informs us, upon classical examples. It is not difficult to infer that his model was Catullus, as the form propounded by him, of regular stanzas with a recurring refrain, is a distinct feature of the poems above cited. This form is indeed adopted by nearly all writers of epithalamia of this period, either by independent imitation of classical models or in acceptance of the canon imposed by Jonson. Among writers of epithalamia at this period we may instance Carew, Beaumont, and Fletcher, Campion, Herrick, Jonson, Shakespeare, Sidney, Spenser, and Suckling, etc. ; and among later poetry there is a fine bridal song by Shelley.

Epithet: 'An adjective indicating some quality or attribute which the speaker or writer regards as characteristic of the person or thing described. $($ I. E. D.). It is not synonymous with 'adjective'.

Epitrite: A foot in classical quantitative prosody consisting of three long syllables and one short. There are four varieties, according to the different position of the short syllable: First Epitrite, $\backsim--$ -; Second Epitrite, - ---; Third Epitrite, --レ-; and Fourth Epitrite, - - -

Epitrope: A rhetorical figure, 'when we either seriously or ironically pernit a thing, and yet ob. ject the inconveniency'; 'a figure of rhetoric by which a permission, either seriously or ironically, is granted to an opponent, to do what he proposes to do'. 
Epizeuxis: 'A figure by which a word is repeated with vehemence or emphasis' $(N . E . D$.$) . '... sort$ of repetition, when ye iterate one word without any intermission'.

Epode: The second line of a distich in Greek prosody, the first being the Proode. More frequently, however, the term signifies the passage of Greek lyric poetry which follows the strophe and antistrophe (see Strophe). The title of Epocies given to a collection of his poems by Horace merely sig. nifies that they were subsequent or an adjition to his Odes.

Épopée Courtoise: A species of early French romance, in subject either merely a work of pure imagination, or based on Celtic or Byzantine legends. They appeared first about the opening of the twelth century, later than the early chansons de geste, and they exhibit the chivalrous spirit in a striking degree. They took the form both of rhymed or assonanced verse and of prose. The épopée courtoise includes such romances as those of Chrétien de Troyes, Robert de Boron, the Perceforest, Roman de la Violette, Aucassin and Nicolette, etc.

Erato: The Muse of erotic poetry; often referred to in the specific sense of that class of literature.

Erotema or Erotesis: 'A figure of speech by which a speaker in the form of an interrogation boldly asserts the opposite of what is asked; as "Creditis avectos hostes?"' (J. W. Gibbs).

Esemplastic : A favourite word of Coleridge's, in. vented by him from Greek roots apparently on the analogy of the German Ineinsbildung (forming inta one), to denote the at tribute of the intellect in moulding into unity, in correlating and unifying subor. dinate facts and truths.

Esoteric: 'Of philosophical doctrines, treatises, modes of speech, etc. ; designed for or appropriate: 
to an inner circle of advanced or privileged disciples " $(\$ . E . D$.$) ; opposed to Exoteric, which means popu.$ lar, untechnical.

Essay : This word had in its literary sense the original meaning of a draft, rough copy; hence it came to mean 'an irregular undigested piece' (Dr. Johnson), and so, by the modesty of the author, a composition unpretentious but complete. Its final and present mieaning is a prose composition of moderate length, limited in range to a single subject. The development of this meaning out of the original sense is no doubt due to the influence of Montaigne's Essais, first published in 1580 .

Estampie : A variety of Provençal poetry written for dancing; a dancing song. Derived from stampin, to beat the ground with the feet.

Estrif: The estrif, dibat, or disputoison was a variety of the early French chanson which flourished in the Middle Ages and was acclimatized in England in the thirteenth century, consisting of a debate or discussion in dialogue; as, for example, The Thrush and the .ightingale, on the merits of women; The Debate of the Carpenter's Tools; The Debate of the Fody and Soul; or The Oul and the Nightingale, in which those birds discuss their own respective nerits. In England this form of poetry, being of the nature of dialogue, exerted considerable in. Huence upon the nascent English drama. The earliest English dramatic piece, The Harrowing of Hell, is nothing but an estrif between Christ and Satan, and is so acknowledged to be by the author in his prologue when he says: 'A strif will I tellen on'. The debate form also gave rise to a form of amusement called 'the king and queen', or 'the king who does not lie ', consisting of the choice of a person to answer questions and the putting and returning of unexpected or amusing questions and answer 
Ethopœia: 'Delineation of character, moral portraiture' (N.E. D.). 'A figure of rhetorick in which there is a feigning of certain words accommo. dated to certain persons, either to their praise or reproach' (Phillips).

Etiologia or Atiologia: The figure of rhetoric in which reasons are given in support of the speaker's allegations.

Euphemism : The practice of alluding to dangerous or unpleasant things by terms expressing contrary characteristics, or, at any rate, which cloak and palliate the objectionable element, as the reference to 'the old gentleman' for the devil. The custom obviously had its root in superstition, arising out of the fear of calling upon oneself the malice of the evil spirit by a too frank description of its qualities ; e.g. the Greek names of the Euxine or 'hospitable' for the very inhospitable Black Sea, and Eumenides or 'kindly ladies' for the Furies. This tendency of euphemism is, as it has been pointed out, the only possible rationalization of the lucus a non lucendo theory of derivation. The term is also applied to the euphemistic appellation itself.

Euphuism: A peculiarly extravagant and affected prose style which sprang into popularity towards the end of the sixteenth century of English litera. ture. It derives its name from a book which prac. tically invented it, Lyly's Euphues, the Anatomy of Wit (1579), followed in 1580 by Euphues and his England. These books, written mainly for women, were romances couched in a peculiar style which was at once hailed as a 'new English', and universally imitated both in conversation and literature. It consisted of constant and forced alliteration and antitheses; it abounded in conceits and word plays, and in curious and far-fetched similes from the mediæ. val bestiaries and herbals. This style, which was imitated by Greene and Lodge and ridiculed by Shakespeare and others, has been ascribed to the 
influence of the Spaniard Guevara, who had been translated by Berners and North. Others hold that euphuism was only the outcome of a pedantic eccentri ity in the air which made itself known in the similar extravagances of Marinism and Gon. gorism (q.v.).

Euterpe: The Muse of Dionysiac music and the double flute; often referred to in the sense of that class of music and its appropriate literature.

Ex-Libris: See Book-plate.

Exargasia: A figure of poetical ornament. 'So doth this figure (which therefore I call the Gorgeous) polish our speech and as it were attire it with copious and pleasant amplifications and much variety of sentences . . . so as I doubt whether I may term it a figure, or rather a mass of figurative speeches, applied to the beautifying of our tale or argument' (Puttenham).

Exchange, The Figure of: The alternative title given by Puttenham in the Art of English Poesy to the figure of Enallage (q.v.).

Exequy: From the title Exequy given by Bishop King (i657) to one of his poems written upon his dead wife, this word has been held to mean a funeral ode; it has, however, strictly no such meaning, but merely signifies funeral rites, or a funeral train or bier.

Exodos: The final sony or choral ode delivered by the chorus in a Greek tragedy as it left the orchestra. It was usually delivered in recitative, not accom. panied by dancing.

Exordium: The commencement, especially of a speech, spoken or written.

Extravaganza: A compo-ition, musical or literary, of obvious and intentional absurdity. 


\section{Fable: See Allegory}

Fabliaux: The name given to a variety of early French literature consisting of short versified tales comic in spirit, intended primarily for recitation; a species of bourgeois poetry of realistic observation which took its rise in the twelfth century and existed side by side with the chivalric poetry of feudalism. They came chiefly from the north and north-east of France, and their output was greatest at the close of the twelfth and beginning of the thirteenth century, coming to an end altogether about 1340. They were caricatures of every class and subject; women, however, they satirized consistently.

Fabula Palliata : The species of Latin Comedy based upon the Greek New Comedy of Menander and Philemon, and representing with a Greek mise en scene the stock characters of the New Comedy. They were written chiefly by Plautus and Terence, by the first of whom the form was popularized, while the latter sought still closer adherence to the Greek originals, excluding the purely Roman refer. ences and customs of which Plautus made use, and striving to write 'as an Athenian, using the Latin language'. 'The name 'palliata' is derived from pallium, the Greek cloak, in distinction from the Roman toga, indicating that the characters were Greek and represented in the Greek dress.

Fabula Prætextata: A variety of Latin tragic drama introduced by Nævius. Tragedy itself in Italy was borrowed from Greece, and both Nævius and Livius Andronicus, his predecessor, had based their tragedies upon Greek originals, with a Greek mise en scène and a Greek plot. Navius, how. ever, produced tragedies upon Roman subjects either of legendary or contemporary history, introducing characters in the garb of Roman magistrates, the toga pratexta, from which the name of this class of tragedy was derived. 
Fabula Togata: The variety of Latin Comedy in which the subject and characters were drawn en. tirely from Italian (not Roman) life, in distinction from the fabula palliata (q.v.), in which the subjects and characters were Greek. The title of this class of comedy, like that of the palliata, refers to the dress of the characters, which was the toga, the ordinary dress of a Roman citizen, in opposition to the pallium, or Greek cloak. There are no complete plays extant of this nature; we possess fragments of pieces by Atranius, their most popular producer. Others were written before him by Titinius and Quinctius Atta, of whom we know little.

Facetiæ: 'Witty, bumorous sayings or writings, pleasantry, droll phrases'.

Falling Rhythm: An accentual rbythm is said to be 'falling' when it commences with a thesis or ac. cented syllable and closes with an arsis or unac. cented syllable, as the accentual trochee or dactyl. The converse is called 'rising'.

Fancy, Poems of: See Classical.

Fantastic Poets : See Metaphysical Poets.

Far-fetched, The: The alternative title given by Puttenham in his Art of English Poesy to the figure of Metalepsis (q.v.).

Farce: Farce in the modern sense may be described as a variety of comedy differing from other species in the grotesqueness and exaggeration of its characters and action. The name farsia was originally applied to a canticle in a mixture of Latin and Frencb sung in many churches at the principal festivals, especially Christmas. It acquired meaning as a dramatic form very early, the term being apparently applied to Lauder's Dcatic of $K$ ingis (1556). There was a dramatic form called Farsa which the Florentine Giovanmaria Cecchi tried to popularize in Tuscany, and which, according to the explanatory prologue 
of one of his plays produced in $\mathrm{I}_{5} 85$, was what we should call tragi-comedy (q.v.). Dryden defines the characteristics of farce in the modern sense as follows: 'Farce is that in poetry which grotesque is in a picture; the persons and actions of a farce: are all unnatural and the manners false'.

Fatura: An Italian term denoting fairy agency in romance, generally associated with or operating through a magic horn, ring, etc.

Feminine Rhyme: A feminine rhyme in Englisb prosody is that in which the penult is the rhyming syllable, the last syllable being common or identical, as 'dying', 'flying'. In French prosody it is the rhyming of words ending in a mute or unsounded. syllable, as 'nature', 'a venture'; such syllable not being counted in the scansion of the line. In thelatter sense it is opposed to 'masculine rhyme', which does not end in a mute syllable.

Fescennine Songs: Ancient indigenous Roman. songs, composed extempore and recited at rustic merrymakings, particularly weddings, generally playfully abusive or licentious. The name is derived from Fescennium, a town in Southern Etruria, where they are said to have been first employed.

Feuilleton: Part of a newspaper devoted to light literature, belles-lettres, etc.; more usually that portion of a newspaper containing the daily quantumb of a novel published by instalments.

Fit: An Anglo-Saxon word originally denoting a verse or poem, mainly used, however, in connection with our ancient ballads and metrical romances to denote a canto sung or recited on a single occasion. Compare Puttenham: "The Epithalamie was divided by breaches into three parts to serve for three several Fits, or times to be sung'. Lewis Carroll revives it pour rire in The Hunting of the Snark.

Flamboyant: A French architectural term answering to what is known as Flowing English, from the 
flame-like forms of the tracery; sometimes applied to a bold and flaunting literary style.

Fleering Frump: Puttenham's alternative term for Mycterism (q.v.).

Fleshly School of Poetry: The title of an article which appeared over the signature of "Thomas Maitland in the Contemporary Review of October, i3 $;$, containing a violent attack upon Swinburne, Kossetti, and William Morris, whom it classed together with O'Shaughnessy, John Payne, Philip Bourke Marston, and others, as exponents of a school of poetical debauchery. This article, which, excusing Swinburne on the grounds of his immaturity, concentrated its virulence upon Rossetti, charged the latter with the treatment of sex rela. tions merely from the sensual side, to the exclusion of all tender and spiritual elements. On December and following it was stated that 'Thomas Maitland' was in reality Robert Buchanan, and some correspondence ensued, from which it appears that while Buchanan, who disclaimed the intention of conceal. ment, was not responsible for the actual pseudonym, it was at his desire that his name was suppressed. The article was subsequently rewritten and amplified, and published in pamphlet form; but Bu. chanan was reconciled later to Rossetti and dedicated to him his novel Goil and the Man in 1882 .

Frottola: A species of Italian canzone, generally comic, in stamzas of various construction, usually composed, however, of short lines.

Full Stress: See Sung Verse.

Fustian: Inflated, turgid, or inappropriately lofty language; speech or writing composed of high. sounding words and phrases; bombast, rant; in early use also jargon, made-up language, gibberish. (N.E. I.) Claptrap; 'fustian, that is, thoughts and words ill sorted, and without the least relation to each other' (Dryden, Dedic. to The Spanish Friar). 
Galimatias: A French term denoting a confused, involved, and obscure style or expression, sometimes almost equivalent to phébus (q.v.). Boileau distinguished two species: that which is unintelligible to the audience, and that which the speaker himself does not understand.

Galliambic: Versus galliambus or galliambic verse consists of four Ionic a minore feet (q.v.) catalectic, that is, with a syllable missing from the last foot:

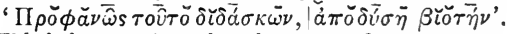
This is its pure form, but there are, of course, many varieties and exceptions. This measure was used by both Latin and Greek poets (particularly in poems addressed to Cybele); by Phrynichus, according to Hephæstion, and among Romans by Varro in his satires, Mæcenas, and Catullus.

Gasconade: Absurd bragging; outrageous boasting such as has come to be associated with American 'tall' stories; the natives of Gascony being proverbially poor, proud, and boastful.

Gay Science, The : The English version of the Prcvençal term El Gai Saber (q.v.).

Genethliaca : According to Puttenham's definition, a form of 'poetical rejoicings'; 'others for magnificence at the nativities of Princes' children, or by custom used yearly upon the same days, are called songs natal or Genethliaca'.

Genre: A term borrowed from the realm of pictorial art, in which it denotes the representation of domestic interiors, of homely everyday indoor life. Applied to literature the term has much the same meaning; thus much of the domestic descripticn and homely life in Dickens may be called genre.

Geste, Chansons de: A species of lyrico-epic ballad which succeeded to and possibly originated in the French cantilènes (q.v.) in the ninth century, dealing with the deeds and achievements of some heroic 


\section{6}

personage, often of semi-historical importance. The oldest surviving chanson de geste is the Song of Roland, probably written in the eleventh century, which, like al! the best. is written in decasyllabic assonanced verse, divided in sections or laisses of varying length, each bound together by a single assonance. Other gestes were Aliscan, Fierabras, and Otinel. They fourished best in the eleventh century, after which time they declined; but even in decline they exerted considerable influence over European literature, giving rise not only to innumerable translations and versions, but also to the libros de cahallerias in Spain, and, generally speaking, to the romance of chivalry everywhere.

Ghazel: A form of Moorish poetry, which had its origin at the Moslem Court in Sicily, consisting of a short ode of fourteen lines; in all probability the origin of the sonnet (q.v.). It was rhymed, rhyme having to Moors a magic or sacred significance.

Glee: From an Anglo-Saxon word, which in many compound and cerivative forms was applied to the old minstrels, and minstrelsy: "glee" originally meant 'minstrelsy'; in its modern sense, however, it denotes a short piece of unaccompanied vocal music in parts.

Glose: A fixed form of French poetry consisting of quatrains with rimes croisées, or after the formula abab, the last lines of which read consecutively constitute a quotation from a well-known poem.

Gloss: Originally, in Aristotle, a word which wants explanation; hence an interpretation or comment upon a word or passage, usually interlinear or marginal.

Glossary: A collection of difficult words or terms drawn from some book or author with their explanations; a dictionary limited to include a special set of words and terms, as those drawn from a special author. art, science, or dialect. 
Gnome: A maxim or brief proverb.

Golden Age of Latin Literature: A term often applied to the best and most flourishing period of Roman letters, viz. that between the years 8 o B.c. and 14 A.D. During this period of the prime "we find prose reaching its highest excellence in Cicero and Cæsar in its earlier half, and Livy in its later; while the generation of the former is marked by the didactic verse of Lucretius and the lyrics of Catul. lus; and that of the latter by Virgil's epic and didactic verse, the lyrics, satires, and epistles of Horace, and the elegies of their younger contemporaries, Propertius, Tibullus, and Ovid'. The latter half of this period, that is from 30 B.C. to 14 A.D., is also called the Augustan Age, inasmuch as it happens to coincide with the reign of the Emperor Augustus. It was followed by a period of decline, usually termed the Silver Age (q.v.).

Goliardic Literature : A collection of mediæval Latin songs, otherwise called Carmina Burana, composed by wandering students and purporting to be the utterances of one Goliardi or Golias. They exhibit a facile handling of mediæval Latin rhyme and rhythm; they entirely discard the chivalrous spirit, and speak of love and wine in terms of frank and carnal naturalism.

Gongorism : An affected and extravagant literary style, named after its inventor, Luis de Gongora de Argote (1561-1627), which, introduced by him into Spanish literature, had considerable influence upon literature in other languages. Possessed with the ambition of marking an epoch in literary history, he conceived the scheme of creating for serious poetry a peculiar and separate diction which he called Estilo Culto, the polished or highly cultivated style. This scheme he carried out by contriving 'a style as affected as it was uncommon, and at variance with all the ordinary rules of the Spanish language either in prose or verse. He particularly strove to 
introduce.. the intricate constructions of the Greek and Latin tongues, though such an arrange. ment of words had never before been attempted in Spanish composition. Not satisfied with this heterogeneous kind of phraseology, be affected to attach an extraordinary depth of meaning to each word. In this style he wrote several works, including his Polyphemus and Soledades, the latter being merely an "insipid fiction, full of pompous myth. ological images, described in a strain of the most fantastic bombast'. In spite of the protests of men of sounder judgment, Gongora had a considerable following; but the affectation became less support. able as it was devoid of the talent which its inventor certainly possessed. His partisans soon separated into two rival schools representing respectively the pedantry and the extravagance of their master. The disciples of the first, termed derisively Cultoris. tos, were content to act as commentators of Gon. gora's most unintelligible works, and to pour forth the stores of their erudition in voluminous glosses and illustrations. The latter school developed the extravagant side of the estilo cuito, dispensing with the precision which liongora thought necessary and always practised. These were called Conceptistos, in imitation of the Italian concettisti or Marinists (q.v.), to whose aims, indeed, their own approximated. Gongorism was introduced into prose by Gracian (d. 16́52).

Gorgeous, The: Puttenham's alternative English term for the figure of Exargasia (q.v.).

Gothic Novel: A class of novel which became popular in the first period of the romantic revival in Eng. land. It dealt with Gothic castles (hence the term), ghosts, murders, weird and strange occurrences, mysteries, rusty suits of armour, tattered banners, and every variety of Wardour Street 'property which could be pressed into the service of the byperromantic and mysterious. Among novels of this 
class may be cited Horace Walpole's Castle of Otranto: The Mysteries of Udolpho, The Castle of Athlin and Dunbayne, The Sicilian Romance, etc., of Ann Radcliffe $\left(x_{7} 6_{4}-1823\right)$, and the works of Chas. R. Maturin (1782-1824) and 'Nonk' Lewis (1775-1818).

Grammalogue: Lit. 'a word-letter', i.e. a letter or symbol standing for a word, as \&.

Grand Opera : See Opera.

Grand Style, The: A famous phrase employed by Matthew Arnold, of which in definition he explains that it 'arises in poetry when a noble nature, poetically gifted, treats with simplicity or severity a serious subject'. His chief examples are Homer, Dante, and, in English literature, Milton, but he also declares that the ancients were its 'unapproached masters'. As a theory of the essence of poetry, a criterion of relative merit, for which it is apparently intended, and indeed openly employed by its creat or it presents great difficulties. As Prof. Saintsbury points out, it is ' $a$ fresh formulation of the Classical restraint, definiteness, proportion, form, against the Romantic vague, the Romantic fantasy'. The doctrine is of a part too with Matthew Arnold's emphasis upon poetic subject-matter as opposed to the value of what Prof. Saintsbury calls the "Poetic Moment'.

Grangerization: The illustration and annotation of a book by the insertion of portraits or pictorial matter. The word is derived from the name of James Granger, who published in 1769 a Biographizcal History of England, with blank leaves for the reception of engravings. The filling up of this and similar books became a popular hobby.

Great Lyric, The: The term applied by Mr. Watts. Dunton to the lyric poetry of the 'Hebrew Poets, who have produced a lyric so different in kind from all other lyrics as to stand in a class by itself. We may perhaps be allowed to call it the Great Lyric. 
. . The Great Lyric must be religious, a rapturous song combining unconscious power with unconscious grace:

Greek Ending: A term frequently applied to the characteristic ending of a Greek tragedy, which does not, as many modern tragedies do, leave the audience in a condition of emotional excitement or elevation provoled by the catastrophe, but restores the feelings to their normal level by the few common. place moralizing reflections with which the chorus usually concludes the play.

Grub Street: A street in the parish of St. Giles, Cripplegate, London, running from Fore Street to Chiswell Street, renamed in 1330 Milton Street. 'It was formerly noted as the abode of small authors, who as writers of trashy pamphlets and broadsides became the butts for the wits of their time'. Hence the term is generally' applied 'to low-class and trashy journalism'. The name 'Grub Street, as oppro. brious, seems, however, to have been first applied by their opponents to the writings of Fox the mar. tyrologist, who resided in the street'.

Graphica Lexis: Written as opposed to spoken style; the Latin version of a term used by Aristotle in the Rhetoric.

Gusto: A word denoting 'taste', which became very popular at the beginning of the nineteenth century in the sense of literary or artistic 'style' as a cant. word of criticism. As such it was a great favourite of Hazlitt.

Half-Stress : Sie Sung Verse.

Harmonies: See Unities.

Hebraism: See Hellenism.

Heel-treading Verse: See Concatenation.

Hellenism: A term used by Matthew Arnold in Culture and Anarchy to denote the ideal or attitude 


\section{1}

to life based upon intellect and appreciation of beauty as opposed to what he calls 'Hebraism', the ideal of conduct and moral discipline, the two constituting the two main streams of influence in literature. 'To get rid of one's ignorance, to see things as they are, and by seeing them as they are to see them in their beauty, is the simple and attractive ideal which Hellenism holds out before human nature; and from the simplicity and charm of this ideal, Hellenism and human life in the hands of Hellenism are full of what we call sweetness and light'. 'Self-conquest, self-devotion, the following not our own individual will but the will of God, obedience, is the fundamental idea of this form, also of the discipline to which we have attached the general name of Hebraism:

Hemistich: A half-verse, half-line, as, for example, either balf of a pentameter or the unfinished bexa. meters in the Eneid.

Hendecasyllabics : Strictly lines of eleven syllables, but more particularly and usually the Phalæcian or Phaleucian Verse (q.v.).

Hendiadys: The use of two substantives coupled by a conjunction in place of a substantive and an adjective, as 'pateris libamus et auro' for 'pateris aureis'; 'with venom and with darts' for 'with venomous darts'.

Hephthemimeral: The cæsura in a hexameter line is said to be hephthemimeral when it comes immediately after the first seven half-feet, i.e. after the first half of the fourth foot, e.g. 'Peli| des que $\mathrm{Ne}$ | optole | mus II pri | musque Ma | chaon'.

Hérésie de l'Enseignement: The term used by Prof. Saintsbury to denote the erroneous view that literature is primarily moral and didactic in some sense, that the great poet is necessarily a good man, etc.

Heroic Verse: In Latin and Greek prosody, verse 
composed in dactylic hexameters, as being the usual medium of epic poetry, which deals with the exploits of gods and heroes. In English prosody, deca. syllabic or ten-syllable verse, rhymed or unrbymed.

Hexameter: Strictly, a verse of six feet or metres. In common parlance, however, the word denotes the dactylic hexameter, the heroic verse of the

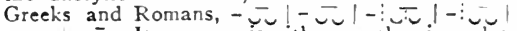
$-\smile-\tau$. Its cæsura is either penthemimeral or hephthemimeral, i.e. either after the first two and a balf feet, or after the first three and a half.

Hexastich: A piece of verse consisting of six lines.

Hiatus: A term in prosody denoting the break or gap between two words, the first of which ends with a vowel or vowel combination, while the second begins with one. In classical prosody hiatus is generally avoided and elision (q.v.) ensues.

Hieroglyphical Writers: The term applied by Hazlitt in his essay On Familiar Style to authors who make use of ready-made epithets, figures, images, and metaphors, without a due sense of their necessity or fitness for the context in which they are employed; for whom the subject suggests a collec. tion of stereotyped phrases and illustrations not inspired by an attempt to clothe any particular thought in appropriate language. 'Such writers have merely verbal imaginations, that retain nothing but words... they never once direct their eyes or lift their hands to seize on any but the most gorgeous, tarnished, threadbare, patchwork set of phrases, the left-off finery of poetic extravagance. ... Images stand out in their minds isolated and important merely in themselves, without any groundwork of feeling-there is no context in their imaginations. Words affect them in the same way by the mere sound, that is, by their possible, not by their actual application. they are the poorest of all plagiar. ists, the plagiarists of words; they soothe the ear by the monotony of the same everlasting round of 


\section{3}

circuitous metaphors'. Hazlitt is especially assailing those in whom this vice is governed by a love of the tawdry and magniloquent, but his analysis is perhaps particularly applicable at the present day to the journalist whose thuds are always either 'dull' or 'sickening', and whose diction on every literary occasion is inevitably drawn from a stock-in-trade of ready-made phrases.

Hilarotragedy: A species of burlesque tragedy or travesty, invented by Rhinthon of Tarentum ( $c$. 300 B.c.). No specimens have survived.

Hill-top Novels : A term originated by the novelist Grant Allen, who classed his works in two categories -those he wrote to please the public taste, and those he wrote to please himself and to express his own sincere opinions on subjects usually deemed indelicate by Mrs. Grundy. The first of this latter series, to which he gave the above title, was The Woman tho Did, which appeared in 1895 .

Hipponactean Metre: This metre consists of a distich, the first line of which is a trochaic tetrapode catalectic, the second a trochaic monometer with anacrusis followed by an ithyphallic, as Horace, Carm., ii, 18:-

'Nōn ěbūr něque aūrěūm

Me | ã rĕnīdět | in đŏmō lăcūnăr'.

Hipponactean Verse: Identical with the Scazon (q.v.) or Choliambic.

Historiographer : An historian or writer of history; particularly an official or professional historian, one appointed by the court, the state, or a great public institution.

History : See Chronicle History.

Homeric Verse: By this is implied the ordinary 'hexameter' verse (q.v.), on account of its being the metre in which the Homeric poems are written.

Homœoptoton: The rhetorical term applied to the 


\section{4}

employment of words in the same cases or inflexions to end consecutive clauses.

Homœosis: Puttenham's term for Simile (q.v.), as a genus including Icon (q.v.), Parable, etc.

Homœoteleuton: The rhetorical figure in which successive words or clauses end with the same sounds; it is a comprehensive term, embracing rhyme, assonance, and all other cases of similarity of termination in successive words, clauses, or lines.

\section{Homonymy : See Metaphor.}

Horatian Ode: The name given to poems composed in stanzas of identically similar structure consisting of lines of irregular length and arrangement, as e.g. Marvell's 'Horatian ode upon Cromwell's return from Ireland'. The reference involved is, of course, to the odes of Horace, to the form of which such poems approximate. The term was employed to distinguish them from 'Pindaric' odes (q.v.), such as those of Dryden and Gray, written in lines of irregular length and arrangement grouped into stanzas which did not reproduce the same structure.

Horismus: Puttenham's term for rhetorical definition by distinction: 'Is this wisdom? No, it is a certain subtle knavish crafty wit', etc.

Hudibrastic: A term frequently applied to poems which. like Butler's Hudibras, are rhymed with absurdly ingenious and far-fetched rhymes, as in his famous couplet :-

'The pulpit, drum ecclesiastic,

He beat with fist instead of a stick'.

Excellent examples of such Hudibrastic rhymes are found in Barham's Ingoldsby Legends. Tbeir use generally imports a comic feeling.

Huitain: The term of French prosody for an eight. lined stanza. Written in octo- or decasyllabic lines, it may be used alone as a fixed form, in which case three rhymes only should be employed. 


\section{5}

Humanism: The branches of learning styled the 'humanities' or litera humaniores, and their study; more particularly the intelligent and appreciative study of Latin, Greek, and Hebrew literature which was one of the chief fruits or causes of the Revival of Learning, and of which the pioneers were mer like Erasmus, More, Colet, etc.

Huntsup, A : A term derived from the first words of an old ballad, 'The hunt is up, the hunt is up'; so denoting a song to rouse sleepers for hunting, and generally any early-morning song to wake sleepers. According to Puttenham, the author of the above. mentioned ballad was one Gray, who for this and other compositions was held in high favour by Henry viii and Protector Somerset. It differs from aubade (q.v.) both in origin, therefore, and in its strict meaning.

Hymeneal: A bridal song, equivalent to epitha. lamium (q.v.) in its more general sense.

Hypallage: The interchange of cases between two words in a construction, or the attraction of an adjective from its appropriate substantive to one to which it does not belong; e.g. 'dare classibus Austros' (for 'dare classes Austris'); 'fontium gelidæ perennitates' (for ' fontium gelidarum peren. nitates '). In Puttenham this figure has no gram. matical sense, but merely signifies the play upon words resulting from such an interchange, as e.g. 'Come dine with me and stay not; come stay with me and dine not'.

Hyperbaton: The grammatical term for the reversing or varying of the natural order of words in a sentence so as to separate words or clauses which should properly come together.

Hyperbole: The rhetorical term for the exaggerated overstatement of a meaning.

Hypercatalectic: This term and that of Brachycatalectic (q.v.) are only applied to metres which are 


\section{6}

scanned, not in single feet, but in dipodies or pairs of feet, viz. in iambic, trochaic, and anapæstic metres. A line in one of those metres is said to be hypercat. alectic when it has an additional syllable or halffoot after the last complete dipody. A form of the bypercatalectic line fund in clasical poetry is that in which (the line being reckoned in two series) there is an apparent excess at the end of the first series of a short syllable which really belongs to the second series, the whole line being regular and uniform if such syllable is reckoned in the second series, viz. $\checkmark-\checkmark$ $-|\cup-\cup-| \cup \|-\smile-\mid \cup-\smile-1$, which might other. wise be scanned $\cup-\cup-|\cup-\cup-| \cup-\cup-|\cup-\cup-|$. Hypodiaresis: A term of rhetoric signifying the 'distribution of the indictment'.

Hypotycosis: The rhetorical term for the 'vivid description of a scene, event, or situation, bringing it, as it were, before the eyes of the hearer or reader (V. E. D.).

Hypozeugma: Sie Zeugma.

Hysteron Proteron: The figure of speech of 'putting the cart before the horse', stating the last of two consecutive propositions first, as Moriamur, et in media arma ruamus'. In Puttenham's Art of English Poesy, however, it does not mean this, but Anastrophe (q.v.).

lambe: The term applied in French prosody to a poem of fixed form composed of quatrains consisting of lines of two lengths, as in the following of $\mathrm{A}$. Chénier (Iambes):

'Quand au mouton bêlant la sombre boucherie

Ouvre ses cavernes de mort,

Pâtres, chiens et moutons, toute la bergerie

Ne informe plus de son sort', etc. etc.

lambics: Strictly, any metre composed of iambi; but more generally the iambic trimeter acatalectic senarius, the usual iambic line of Greek tragedy, 
composed of six iambic feet (or three dipodes) complete.

Iambus (Greek, $\imath^{\prime} a \mu \beta$ s ) : The metrical foot, consisting of a short syllable followed by a long one $(u-)$.

Icon: The rhetorical figure of the likening of features or qualities in a person to other objects; poetical imagery, as e.g. ' Her neck is like a stately tower'.

Ictus: The term in prosody denoting beat or accent; stress.

Idealism : Idealism in literature and art is, roughly speaking, the attitude to life and to the worid which turns from the ugly and repulsive in the particular in search of a higher principle of beauty which in. forms the universe; the effort to realize the highest types by eliminating the elements of imperfection, and to obtain a perception of the great and beautiful truths underlying life by omitting to dwell on the sordid particulars.

Idyll or Idyl : Lit. 'a little picture of life', which is the meaning of the word as applied by Theocritus to his poems. Its connection with pastoral poetry has, however, given the term a connotation of Arcadian simplicity or charming guilelessness, also expressed in the adjective 'idyllic', and the modern use of the word implies a picture of anything but realistic life. In general the word is now used to denote a representation of a scene or episode usually of a graceful and delicate nature. In the title of Tenny. son's Idy'lls of the King the word apparently means little more than 'episodes'.

Illuminism : See Auf klärung.

Illustrious, The : In histreatise De Vulgari Eloquio, Dante, after examining all the local I talian dialects and finding no one of them worthy of ranking 25 'the illustrious vulgar tongue', proceeds to discuss the qualities which go to form such a tongue, which constitute the common measure or norm of all the dialects, 'perceptible in all, abiding in none'. These 
qualities, he concludes, are four, viz. the Illustrious, that which shines forth, exalts those that practise it, and confers glory; the Cardinal, that upon which all the dialects turn, as upon a hinge; the Aulic, that which would be spoken in a court, if there were an Italian court; and the Curial, that which would be spoken in the great law courts of Italy, if there were any. The combination of these elements is the ideal Italian at which all the dialects aim, though severally they fall short in different ways. It is, in fact, an attempt to arrive at a literary Italian with all the merits of the local dialects and none of their defects.

\section{Imagination, Poems of: See Classical.}

Impressionism: Strictly, a term of painting denoting the depiction of the broad salient features of a sub. ject which meet the eye without any attempt at finishing in detail. Hence in literature it denotes the style which attempts to convey the desired meaning by a few brcad touches, by sketchy outline, without laborious description.

Imprint: The contents of the title page of a book, especially the part relative to the publication, viz. date, place, and printer's name, etc.

Improvvisatore: One who can compose and recite verses extemporaneously, a faculty restricted to Italian, as the origin of the term suggests, on account of the superior ease and fluency of rhyming afforded by that language. After the Renaissance, however, there were improvisatori in Latin as well as Italian.

Index Expurgatorius: A list promulgated by the Pope of erroneous and heretical passages to be expunged from the literature of the day.

Index Prohibitorius : A list promulgated by the Pope specifying such works as the faithful are forbidden to read on account of the erroneous teaching contained therein. 
Induction: A preface or introduction, as e.g. Sackville's famous 'Induction' to the Mirror of Magistrates $\left(1_{5} 6_{3}\right)$.

Inkhorn Terms: The phrase applied by Thomas Wilson in his Art of Rhetoric (1553) (though its use is not original with him) to out of the way and pedantic phraseology, 'archaisms, technicalities, preciousnesses'.

Imprimatur: This Latin word, meaning 'let it be printed', was the form used in licensing books for printing, and is thus employed to denote the licence itself. It is, however, generally used in the incorrect sense of approval, sanction.

Insertor, The : The alternative title given by Puttenham in his Art of English Poesy to the figure of Parenthesis (q.v.).

Intercalaris, Versus: The refrain verse, a particular feature of amœbean poetry, and, like that variety, of Sicilian origin. Cf. Virgil, Bucolics: 'Incipe Mæna. lios mecum, mea tibia, versus', which line recurs at intervals after the manner of a refrain. Cf. also the refrain in Catullus, lxi, lxii. The versus intercalaris is employed by Aschylus in the Agamemnon and Eumenides: it was probably derived by him from Sicilian sources.

Interludes: A species of dramatic performance in England which formed a transition stage between the miracle or mystery and the drama proper. They were considerably shorter than their forerunners, being, as the name implies, of such length as to be performed in the intervals of a banquet or other solemnity. They inherited a didactic spirit, but took on a greater variety of theme. One of the earliest is Hyckescorner, imitated by the author of the Interlude of Youth (about the time of Queen Mary). Other specimens are Lusty Juventus, Marriage of Wit and Wisdom, Now Custom, Skelton's Magnificence, Interlude of the Four 
Eiements, Heywood's Play of Love and Dialogue of Gentle'ness and Vobility, etc. etc.

Interpolation: The insertion in a MS. or any literary work of spurious words or passages. The term is aiso applied to the matter so inserted.

Interruption, Figure of: See Silence, Figure of. Inversion: See Anastrophe.

Ionic a Majore: The species of metrical foot consisting of two long syllables followed by two short, as - $\smile$. It was a clumsy and coarse measure, and rejected from more elevated poetry, being used chiefly for obscene and satirical poems, which were not sung. but recited with ludicrous gestures.

Ionic a Minore: The species of metrical foot the reverse of the forezoing. Consisting of two short syllables followed uy two long, $\smile--$, as 'misërärum ist.

Irmus: The fizure of many consecutive incomplete ciauses compieted $y$ the verb in the final clause, which applies to all, as e.g. Shakespeare's sonnet - rired with all these, etc., where the final couplet sums up and completes the preceding lines.

Iron Age of Latio Literarure: A name sometimes applied to the eariy period of Latin letters between the years 250 and 40 B.C., during which period a literature was evolving from the earliest beginnings. - During this time the Romans were learning, first in verse and then in prose, to imitate the great Greek writers, and were attempting at least one if not two important branches of literature-satire and didac. tic verse-on lines of their own devising. Here we thave tragedy, comedy, and epic verse all written with more or less success, and the beginnings of history". The great names of the age are: Livius Andronicus, Nevius. Ennius, Plautus, Cato the Censor, Cacilius, Terence, Afranius, Pacuvius, Accius, and Lucilius. The peculiarity of the whole age is the clumsy and rugged character of the lan. 
guage as it first, so to speak, becomes a vehicle of literature: hence the term. It was followed by the Golden Age (q.v.).

\section{Irony, Socratic: See Socratic Method.}

Irony, Tragic: The term applied to the situation, in Greek and other drama, in which the audience are aware of some impending catastrophe or important fact of which the characters are either totally ignorant or not fully aware, a condition rendered possible by the fact that Greek drama dealt with legends known to all the spectators. Irony has, of course, in this phrase the Greek meaning of 'dis. sembling'.

Isopets: The name given to various co.lections of fables in French translated from Phædrus and Avianus. These received special honour on account of the desire of ecclesiastical writers in the Middle Ages to give prominence to that section of classical literature best suited to the purpose of edification. The term was derived, of course, from Esop, but the name is given to all collections irrespective of their source. A great collection made about 4450 by Steinhoewel was translated into French, and formed the chief source of later collections, including, renıtely, La Fontaine's works. Their literary value is small.

Ithyphallic Verse: This measure is a line consisting of a trochaic tripode acatalectic, viz. $-\cup-v-v$.

Jacobean: An epithet used to distinguish the English writers of the reign of James $i$. They can hardly be said to constitute a period: the division of the epoch of Shakespeare and Jonson at the accession of James $i$ is purely arbitrary. The death of that sovereign in 1625 did, however, mark the close of an epoch with the general decline of the romantic drama and the silence of Jonson. 
Jagati: A Vedic metre (quantitative) consisting of three feet each containing four syllables. The first two feet are composed of syllables either short or long; the third must consist of two iambi, as $u x u x$ | $\checkmark \smile \cup \cup \mid \smile-\smile$ -

Jeu d'Esprit: A witticism.

Jeu Parti : A form of Provencal poetry consisting, like the 'tenson', of a sort of disputation. One of the supposed disputants proposes two contrary solutions of some poetical or amorous question, and defends whichever his opponent refuses to accept. The earliest jeu parti is attributed to Gace Brulé and Count Geoffroi of Brittany, and belonas to the second hai of the twelfth century. Its Provençal name was Fartimen; lew Parti being the name it bore in the more northerly regions.

$\mathrm{Jig}$ : In its literary sense a jis was a kind of entertain. ment in rhymed verse, partly sung and partly recited. 'A jig was a ludicrous metrical composition often in rhyme, which was sung by the clown, who occasion. ally danced, and was al ways accompanied by a tabor and pipe "(Halliwell). In this sense the word occurs in Shakespeare.

Jobelins: In 1640 the literary salons of Paris and the frecieuses who thronged them became divided as to the rival meriss of two sonnets, one upon Job by Penserade (16r2-0r), the other upon Urania by Voiture (1598-1643). Those who took the side of Benserade were styled 'Jobelins', those who favoured the merits of Voiture, 'Uranistes'.

Johnsonese : A term applied to the diction peculiar to Dr. Jobnson $\left(x_{709-84}\right)$, which is excessively. turgid and inflated, and mainly composed of Latin derivatives and compounds, often coined by the Doctor himself. As far as can be judged from his works, Johnson did not develop this style gradually, but struck it out and adhered to it from the begin. ning. He spoke, however, usually in more ordinary English. Macaulay says: 'When be wrote for 


\section{3}

publication, he did his sentences out of English into Johnsonese'.

Journalese: A term sometimes applied in ridicule to the inferior literary style of the average hack journalist.

Kailyard School of Fiction: The term often applied to a class of recent fiction which purports to descrihe common life in Scotland with much insistence upon dialect or vernacular. The title was taken from the first line of a Jacobite ballad, 'There grows a bonnie brier bush in our kailyard ', with direct reference to a novel by Ian Maclaren (one of the most popular examples of the school) called Beside the Bonnie Brier Bush (1894). Among other members of the school may be classed J. M. Barrie, S. R. Crockett, J. J. Bell, etc.

Katharsis: See Catharsis.

Kenning : A characteristic ornament of Old English as well as of Early Teutonic in general. consisting of the use of periphrastic expressions instead of the simple name of a thing, as 'oar-steed' for ship; 'storm of swords' for battle. The term is derived from the mediaval Icelandic treatises on poetics.

Knickerbocker School: A term applied to a group of New York authors who lived in the middle of last century, and to the phase of American periodi. cal literature which they represented. The most characteristic member of the school was Nathaniel Parker Willis; others were Boker, Bayard Taylor, Saxe, Tuckerman, Curtis, and Seward. The name is derived from the Knickerbocker Magazine and the Knickerbocker Gallery (a miscellany which appeared in 1855 ), to both of which they con(ributed.

Laconic Verse (Versus Laconicus): This measure consists of an anapæstic tetrameter catalectic with a spondee in the seventh foot, $\widetilde{U}-\bar{U}-1 \overline{0}-\widetilde{U}$

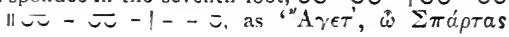




\section{4}

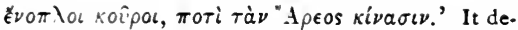
rives the name above given as being used by the Spartans as a marching rhythm. With the seventh foot either an anapæst or a spondee it was used in comedy by Aristophanes, Aristoxenes, Epicharmus, and Cratinus. Hence the ordinary anapæstic tetrameter cat alectic is sometimes called Versus A ristophaneus.

Lacuna: The term employed in textual criticism to denote a gap or break in a text occasioned by damage to the manuscript.

Lai : The term originally applied to Breton melodies, and hence to the words adapted to such melodies. The term desiort is also applied to such words, implying that each stanza is in discord with the others. In French literature it denotes a poem divided into 'couples' or stanzas, each of which has two rhymes only. These rhymes may be arranged in any possible way, except that the same arrange. ment must be fourd in the last stanza as in the first. The rhymes are not distributed evenly throughout each stanza, but one of them predominates. The lines are frequently of unequal length, many halflines being introduced, and as in writing or printing both long and short lines start beneath one another, the right-hand margin of the text exhibits an irregular appearance similar to that of a tree thrusting forth horizontal boughs, on account of which the lai has received at times the name of arbre fourchu. Lais were written by Guillaume de Machaut in the fourteenth century, and many others, but chiefly by Alain Chartier (c. 1392-c. 1433).

Laisse: The term applied in French prosody to denote the passage or series of lines having the same assonance.

Lake School, Lake Poets, Lakers, or Lakists: The nickname given originally in derision to a group of poets, the most prominent of whom were Words. worth, Coleridge, and Southey, from the fact of 


\section{5}

their residence in the Lake District of Cumberland The classification was first made by Jeffrey in an article dealing with Southey's Thalaba in the Edin. burgh Review (October 1802), which referred to that author as one of ' a sect of poets' possessed with the intention of founding a school upon (I) 'the anti-social principles of Rousseau'; (2) 'the simplicity and energy (horresco referens) of Kotze. bue and Schiller'; and (3) 'the homeliness and harshness of some of Cowper's language and versification interchanged occasionally with the innocence of Ambrose Philips or the quaintness of Quarles and Dr. Donne'. The assault was maintained by the Edinburgh Review with the assistance of others, chief among whom was Byron, who lost no opportunity of ridiculing Wordsworth and detested Southey. The establishment of Blackwood's Magazine, however, which took up the challenge on behalf of the Lake School, under the editorship of Christopher North, himself a Lakist, and with the powerful support of De Quincey, Lamb, Hazlitt, and Leigh Hunt, changed the situation, and as Wordworth's reputation advanced Jeffrey was fain to admit his genius. The London supporters of the school had been generally recognized by the Edin. burgh Revieav as included in its ranks, but in the hour of triumph this section was disowned by the cause they had championed, and in the second volume of Blackwood Lockhart launched a virulent attack upon Hazlitt, Leigh Hunt, and Lamb, under the contemptuous designation of the Cockney School (q.v.). The term Lake School is still employed as a matter of convenience, but there is, of course, no such similarity of style or aim in the works of its original members to justify their classification as a 'school'. Apart from the fortuitous event of their residence, and the fact of their friendship, mutual respect, and admiration, the only common feature which can be ascribed to them is their deliberate desertion of the 'Augustan' models, which had to 
that time been unchallenged. As apostles of Romanticism they deserve to be classed together.

Lampoon: A piece of violent personal invective or satire.

Laureate, Poet: The poet laureate is at present a court official appointed by the ministry in power for life. His duties are to compose verses on occasions of importance at court, in return for which he re. ceives a yearly stipend of $£_{200}$ and a butt of sack. Little very defuite can be ascertained concerning the origin of the post and its title, though it was carefully investigated by Selden. The following is, however, an outline of its possible history. From the very earliest days of Greece and Rome the practice obtained of crowning poets with laurel; it was abolished, however, in the reign of Theodosius as pagan, but revived in the thirteenth century when Petrarch was publicly honoured with the bays. About the same time the degrees of Bachelor and Doctor were established at the universities and conferred with the same public honour; and popes and sovereigns adopted the practice of bestowing the laurel. Leo $x$ crowned a court buffion as arch. poet: Maximilian founded in 1504 a poetical college at Vienna, reserving himself the right of conferring the laurel crown. There were poets regal in France, though not laureate; while the latter title was apparently known in Spain. From time immemorial English kings have had a court dependent, some. times entitled the 'king's poet' or 'king's versifica. tor', occupying a post similar to that of the king's jester. Many early English poets, moreover, assumed the title of 'laureat', as Gower, Chaucer, Skelton, and John Kay; but there is no trace of the honour ever having been publicly conferred upon poets in this country. It may well be, however, either that those poets assumed the title as a distinction without having actually had the laurel con. ferred upon them, or that it merely implied that the 


\section{7}

poet so designated had been 'laureated' at a university. The assumption of it by the court poet a: an adjunct of his office may have arisen by the stereotyping of either practice.

Legend: Originally, anything to be read, any book; later, a book containing the lives and records of the saints and martyrs, sich as the Golden Legend of Jacobus de Voragine (thirteenth century). The term now denotes the stories and fables accruing round the name of a mythical or semi-mythical hero.

Leg-of.Mutton School: The title bestowed by Lockbart upon a class of literary parasites and sycophants of his day who in return for hospitality and patronage acted as mouthpleces of their patrons' virtues and magnificence. It was invented in the course of a review or an absurd anonymous poem written in extravagant adulation of the Duke ot Roxburghe, entitled Fleurs: A Poem in Four Books. -The chief constellations in this poetical tirmameni consist of led captains and clerical hangers*on, whose pleasure and whose business it is to celebrate in tuneful verse the virtues of some angelic patron who keeps a good table and has interest with the Archbishop or India House. . . He (the Bard ot Fleurs above mentioned) is marked by a more than usual portion of the qualities characteristic of the Leg-of-Mutton School; by all their vulgar ignorance, by more than all their clumsy servility, their tawning adulation of wealth and titles, their hanker. ing atter the flesh-pots, and by all the symptoms of an utter incapacity to stard straight in the presence of a great man' (Blackwood's Magazine, vol. ix).

Leonine Rhyme: See Rime Leonine.

Leonine Verse : Latin hexameters or elegracs in which the halves of each line rhyme, as, tor example, it More's epitaph upon a singing man at Abingdon?

- Hic jacet Henricus, semper pietatis amıcus : Nomen Abyngdon erat, siquis sua noniina qua 


\section{8}

In French prosody Lers Léonin has much the same sense, consisting of lines in which the same syllable is repeated both at the cæsura and the end.

\section{Lesbian Verse: See Sapphic.}

Letter-hunting: A term applied to the deliberate pursuit of alliteration; also to the variety of lipo. gram which consists in the exclusion of words beginning with every letter but one.

Lever du Rideau: See Curtain Raiser.

Libretto: The term usually applied to the words of any song, cantata, or operatic composition. It actually means 'little book', with reference to the 'book of words' of an opera, which is often printed separately.

Libros de Caballerias: The Spanish term for the chivalric romances of which that country was exceedingly fond, such as the numerous Amadis and Palmerin romances. See Romance.

Like Letter, The Figure of: The alternative name given by Puttenhan in his Art of English Poesy to the figure of 'Parimion', by which he appears to mean alliteration (q.v.).

Like Loose, The: The alternative term given by Puttenham in his Art of English Poesy to the figure of Homœoteleuton (q.v.).

Limerick: A form of nonsense verse consisting of five lines, two of eigt or nine syllables followed by two of six syllables and concluded by one of eight, written in anapestic or dactylic rhythm and rhymed after the formula aabba. The Limerick should conform pretty closely to the well-known example:-

'There was a young lady of Riga

Who went for a ride on a tiger;

They returned from the ride

With the lady inside,

And a smile on the face of the tiger'.

This type of nonsense verse was first popularized by 


\section{9}

Edward Lear in his Book of Nonsense, published in $\mathbf{1 8 4 6}$, but the actual form was not original in him, as he expressly states in his preface to the third edition that he was indebted, at the suggestion of a friend, to certain nursery rhymes beginning "There was an old man of Tobago'. It is said that the name is derived from the meetings of certain convivial spirits, who made a practice of the extempore composition of these verses, their recitation being followed in each case by the chorus, "Will you come up to Limerick?'

Linking-Verse: The name given by Puttenham in his A rt of Englis/2 Poesy ( ${ }^{18}{ }^{8}$ ) to the repetition of the same line at the end of each stanza of a set of verses by way of refrain, as in Sidney's "My true love hath my heart and I have his', which is the example adduced by him. He says: 'The Greeks called such linking-verse Epimone, the Latins versus intercalaris; and we may term him the love-burden, following the original, or, if it please you, the long repeat'.

Lipogram : A poem or piece of literary composition so written as to exclude a certain letter, its varieties ranging from the omission of a single vowel or consonant to that of all vowels save one, a very popular form. This species of literary trifling is of consider able antiquity, one of the earliest, and certainly the most astounding example, being two poems written by Tryphiodorus early in the Christian era. These were an Iliad in twenty-four bøoks, the Greek letter marking the number of each book being respectively omitted throughout such book, and an Odyssey composed on the same lines. According to Athenæus, Pindar wrote an ode without the letter $\sigma$, and there were numerous examples through the Middle Ages. Lope de Vega wrote five novels, each of which avoids one particular vowel.

Litotes or Meiosis: The figure of speech in which the intended meaning is conveyed by ironical under. statement. 


\section{0}

Livraison: A section of a book printed and pub. lished separately. as a number in a series.

Loas : Little preludes or recommendatory piees pre. fixed to Spanish comedies in the tume of Lope de Vega.

Locus Classicus: The place or passage in any book tc whicb reference is usually and nctoriously made as ar. example of any particular word or usage of speect or as the chief source of intormation upon any subject.

Logogram. Alsc called a phonogram or word-letter. $A$ letter or ietters standing as an abbreviation tor a word or phrase, as: z.e. for id est; e.g. for exempli gratia; M.A. for Masier of Arts.

Logogripi: A sort of riddle or verbal catch.

Long-Loose. The: The alternative title bestowed by Putterbam in his Art of English Poesy to the figure of Irmus (q.v.).

Loose Language: The: The alternative name given by Puttenham in the Art of English Poesy to the figure of Asyndeton (q.v.).

Love-Burden: See Linking-Verse.

Ludi Osci: See Atellan Plays.

Lullaby: A cradle song, something sung to put children tc sleep; in derivation akin to tbe verb 'to lull'.

Lyons: School of: The name given to a literary circle which gathered round the famous Lousse Labć (1525-66): a remarkable woman, who at one ame actually served in wartare under the soubri. quet of Capitaine Loys, and who was an accom. plished musician and poetess. The best known of those whc frequented the house at Lyons of 'La Belle Cordiere' (as she was called after her marrage to a rich ropemaker) were Maurice Sève. Pontus de Thyard, and Olivier de Magny, though the last twc are often classed among the Pléiace. 'The tendency of the school it general, thougb 


\section{1}

platonlc, adhered to the Marot tradition; it formes in effect a transition from the school of Marot to that of the Pléiade.

Lyric: By etymology, and in its most limited sense, poetry written for the lyre, and intended to be sung. On a deeper analysis of what is termed lyrical poetry, however, we find it so called by reason of its personal and egoistic quality. The spirit of lyric is entirely opposed to the spirit of drama: that is objective, external; while lyric is always the outcome of strong personal and subjective feeling. The tyric poet is a poet with one voice, the voice of his own personality; while the dramatic poet has so many voices that his creation takes upon it the tinge of life, and the poet is forgotten. The lyric poet is never lost in his poetry; the lyric cry is his cry, vibrating not with the universalized emotion of the drama, but the note of a passionate individualitv.

Lysis: The term (lit. 'an unloosing') employed by Aristotle in the Poetics to denote the dénouement or group of events following the decisive situation of a tragedy or dramatic piece. The whole of the action previous to the catastrophe or decisive turn is according to this terminology the desis or compli. cation, the interweaving of characters, events, clash. ing wills and purposes which compose the plot and lead up to the central situation, the climax of the action. Thereafter the dénouement follows, the unravelling of the threads so interwoven, proceeding in necessary and inevitable sequence to the conclusion. It is required that this solution of the central situation should follow logically from the characters and situations already presented without recourse to violent improbabilities or assistance foreign to the plot. Hence it was regarded as bad art to solve the difficulty by the gratuitous introduc. tion of a god or hero, the deus ex machina. In the words of Horace, 'Nec deus intersit nisi dignus vindice nodus: 


\section{2}

Macaronic Literature: The term given to a com. position of scraps of different languages, probably derived from the miscellaneous character of a dish of macaroni, mueh as the lanx satura gave its name to satire. In its narrower and stricter sense, however, it denoted a jumble of Latin (or Greek) with the vornacular, in which the latter is inflected with the forms of the older languaze, as e.g. "Trumpeter unus erat, qui coatum scariet habebat'. In this sense (the original, be it said) it certainly took its rise in burlesques of monk Latin or the jargon of Norman law Latin. I he earliest known author of this class of literature was Odaxius of Padua (c. 1450), who was followed by Teofilo Folenzo and others. The Epistola ('iscurorwm l'ironwm are a sort of macaronic prose, and are said to have caused Erasmus much amusement. Dunbar is said to have been the first to have introduced it into England in his Testament of Antreav Kennedy ( 1503$)$, but his is a distinct variety, which has given birth to a separate progeny, and consists of Scotch and Latin, the latter partly of the dog variety, in alternate lines, as :-

\section{'I will na priestis for me sing \\ Dies illa, dies irze, \\ Na yet na bellis for me ring \\ Sicut semper solet fieri ${ }^{3}$, etc.}

This is possibly the origin of such verse as the Boar's Heat Ciarol, but the true macaronic style was apparently introduced by Skelton in his Colin Clout and Phlip Sparrou (1512). The earliest important piece of macaronics is the comedy of I gnoramus by Ruggle, a burlesque of legal jargon which is said to have given James $\mathrm{i}$ great delight. There is also Drummond of Hawthornden's Polemo . Hiddinia, and numberless other examples ancient and modern.

Macrology: Long and tedious discourse; super. fluity of words.

Madrigal: Originally, it appears, a theme for impro. 


\section{3}

visation, then the harmonization of such songs as had become popular, and finally, part music with distinct phrases or melodies, not mere concord of sounds, as a glee may be. "The madrigal may be defined as a piece of secular vocal unaccompanied part music. It is frequently set to words containing some little sentiment of worldly wisdom. The true form should consist of a series of conversational phrases, or of passages in imitation, one part answering another, and interwoven so as to form harmony. The whole should constitute one movement' (F. A. Cox). Hence the word has been applied to the words so set to music or to lyrics suitable for setting. The vogue of the madrigal commenced in Italy at the beginning of the sixteenth century, and spread thence to other countries, attaining the height of its popularity in England at the end of the sixteenth and the early part of the seventeenth century. Between $\mathrm{r}_{5} 88$, indeed, and $163^{3}$ over ninety-two collections were published, to which we are indebted for some of our most beautiful lyric poetry. It has been attempted to prove that the madrigal was a specific form of regular literary composition, but this is extremely doubtful. Drummond's 'madrigals', for example, are merely brief irregular odes, while in the language of the above-quoted author 'nothing is a madrigal unless the musician will it so, while anything is a madrigal provided the musician so will it '. In the majority of cases what was set was a sonnet, an odd stanza or two out of some poem, neither written expressly for music, or a lyric out of a play or romance: we may note an exception perhaps in the case of Campion, who, writing both words and music, naturally wrote his words in many cases expressly for setting. The origin of the word itself is somewhat obscure. Littre states it to be derived from the Italian madriale, L. L. matriale, some kind of song; others have suggested that it originally meant a song in praise of the Mother of 
God (madre). It is interesting to note however. that there is a town of this name in Old Castile, and that there was another many years ago in South America.

Malapropism: A term sometimes applied to the ignorant use of words and phrases in mistake for others which they resemble in sound. It is derived from Mrs. Malaprop, a character in Sheridan's Fivals, whose name is again derived from the French mal à propos. This character throughout the play makes errors of speech such as 'caparisons are odorous'.

Mannerism: A peculiarity of style pushed to the degree of affectation.

Marching Figure, The: Puttenham's alternative English title for the figure of Climax (q.v.).

Marinism: A term applied to the characteristics and influence of the writings of an Italian poet, Giovanni Battista Marini (r56g-r625). His chief work. Adone (10.23), is nothing but a succession of cescriptions in word painting, brilliant and luscious from the exterior, but of no originality in outlook, no plot, moral, or characterization. His style is not cevoid of beauties, but disfigured by far-fetched concelts. 'The most whimsical comparisons, pom. pous and overwrought descriptions, with a species of poetical punning and research, were soon esteemed under his authority as beauties of the very first order (Sismondi). His influence was, however, for. tunately checked by the sterner genius of Chiabrera, who looked to the Greek lyric poets for the molel of the Italian canzone. Sce also Euphuism.

Marivaudage: The term applied, usually in depreclation, to the peculiar style of Marivaux (ros31763 ), the French dramatist and novelist. It is his novels, however, and in particular that entitled $L a$ I ie de Marianne, which gave rise to the phrase. That mentioned in all probability exercised sone influence upon Ricbardson which may be traced in 
Pamela. His peculiarity consists in the fashion in which the characters relate their adventures, de. scribed as 'sometimes a refined and novel mode of expressing delicate shades and half-shades of feeling, somes an over-refined or over-subtle attempt to express ingenuities of sentiment'. La Harpe says: 'C'est le mélange le plus bizarre de métaphysique subtile et de locution triviale, de sentiments alambiqués et de dictons populaires'. In general his works exhibit a good deal of acute feminine psychology with a pervading flavour of what used to be called sensibility, and is not remote from what is now called sentimentality.

Martinist: The term applied to writers and writings connected with the famous Martin Marprelate controversy. Towards the end of the sixteenth century the discontent of the growing Puritan party against episcopacy came to a head in a vigorous campaign of anonymous or pseudony* mous pamphlets, most of which purported to be from the pen of "Martin Marpreiate'. The chief authors on the Puritan side were John Udall, who died in prison; Henry Barrow, John Penry, both of whom were executed; and Job Throckmorton. There were replies on the part of the bishops by Cooper, then Bishop of London, and others, includ. ing Lyly and Nash. The output of these pam. phlets was most persistent, in spite of the rigour with which they were attempted to be suppressed. The pamphlets themselves mainly had recourse to bitter personal attacks and savage idulpoonery. They were, however, extremely vigorous and earnest, and by no means lacking in humour.

Martyrology: A book dealing with martyrs, as Fox's Book of Martyrs; also the study or history of martyrs.

Marvels: Another term for Miracle Plays (q.v.).

Mascarade: A term in French literature denoting verses written for recitation by masked characters; 
possibly a sort of masque literature. Boileau refers to the term, but its exact meaning or history is unknown.

Masculine Rhyme: A rhyme is called masculine in French poetry when the rhymed words do not end in an e mute (e.g. bonté, beauté; soupir, désir), as opposed to the rime feminive of words which end in an e mute, as zictoire, gloire; discrète, poète. The third person plural of the imperfect and conditional tenses ending in aient are regarded as masculine. The term 'masculine', as applied to rhymes in English poetry, denotes those falling on the last syllable, as repent, consent, as opposed to Feminine Rhymes (q.v.) where the rhyme falls on the penulti. mate syllable or Sdruccioli (q.v.), where the rhyme falls on the antepenultimate.

Masque: A form of literary composition, part dramatic, part lyrical, interspersed with music and musical accompaniment, which won great popularity in the sixteenth and seventeenth centuries of Eng. lish literature. The word itself is derived from the Arabic maskharat, a buffoon, jester, through the Italian maschera, and, indeed, it was from Italy that the masque itself came to England. Its earliest form is a matter of conjecture; it probably origin. ated in the Italian masquerade and pageant, or a fusion of them. The first, which was only pro. duced in private, was a sort of allegorical ballet; the second was a public performance somewhat resembling the London Lord Mayor's show, and took its rise in the Florentine trionfi (q.v.). Pageants (q.v.) developed in England on separate lines, but the masque was always a private matter, its great expense precluding its performance except at the cost of wealthy individuals or institutions. It was the union of the arts of architect, musician, and poet, though the latter's part was not always of importance, and it was not always regarded as a chiefly literary production. The acting required 


\section{7}

was, however, not beyond the capacity of amateurs, for whom masques were chiefly written, kings, queens, and great nobles often taking part. It flourished in particular through the reigns of James $i$ and Charles $i$, and being essentially an amusement of the court and nobility, it came to an end with the civil wars. In its slightest form it was merely a sequence of dances in an appropriate scenario with a few madrigals; but it often approximated to a little play relieved with songs and dances. The actors generally wore masks. Masques were written by Jonson (35), Beaumont, Fletcher, Chapman, Campion, Daniel, Dekker, Middleton, Marston, Shirley, Carew, and Milton. The chief masque musicians were Ferrabosco and Lawes, while Inigo Jones provided scenery for many. The expense of masques was prodigious. Shirley's Triumph of Peace (1634) cost the four Inns of Court £2r,000 in the money of that period. It was the practice, apparently introduced by Jonson, to include occa. sionally what was known as an Anti-Masque, the nature of which is best explained by Jonson in bis introduction to the Masque of Queens: 'Her Majesty (best knowing that a principal part of life in these spectacles lay in their variety) had commanded me to think on some dance or show that might precede hers and have the place of a foil or false masque'. It was therefore a comic interlude, a sort of parody of the masque proper, intended to set off the stately magnificence of the rest. Some. times it was a dance and dialogue of rogues or beggars absurdly or fantastically attired, and its object was to introduce a scene of real life, of boisterous humour or comic dialogue, amid the lofty personifications of mythology, serving in a way by affording comic relief much as the satyric drama in Greek tragedy. It was always performed by professional actors. Ben Jonson uses the form AnticMasque in one place, but merely by way of a pun, the actors being 'anticly' attired. The probable 


\section{8}

derivation of the word is 'anti', masque, a foil or antithesis to the masque.

Meiosis : See Litotes.

Meistersinger (German, lit. 'master-singer'): One of a class of German poets and musicians which succeeded the Minnesingers (q.v.). It consisted chiefly of peasants and artisans, who formed guilds for the cultivation of poetry in the fourteenth century. "Nuremberg was their principal seat, and Hans Sachs, a shoemaker of that place, was the most celebrated of them ; but societies were founded in all the principal cities, many of which were maintained till the seventeenth century, while that of Ulm continued in existence till 1839 .

Melic : The more elaborate form of Greek lyric poetry as distinguished from elegiac and iambic poetry.

Melodrama: Strictly a dramatic piece in which music is introduced, an opera; hence a drama with incidental music, an operetta with spoken dialogue or a piece in which speech and song alternate. In common parlance, however, a drama of highly coloured, sensational, or romantic incidents.

Melpomene: The muse of tragedy; frequently re. ferred to in the specific sense of that class of litera. ture.

Memoir: A prose work either biographical or auto. biographical; frequently containing discursive matter, such as table-talk, anecdotes, etc.

Memoria Technica or Mnemonics: Versions of useful information cast either into rhyme, metme, or some sort of cypher, with the object of their being easily learned and quickly remembered, as, for example, the verse about the months-'Thirty days hath September... ; the couplet giving the towns which claimed Homer as a native-'Smyrna, Chios, Colophon, Salamis, Rhodos, Argos, Athenæ', etc.: or the line giving the Ecumenical Councils in their chronological order - 'Ni.Co.E | Cbal.Co-Co | $\mathrm{Ni}$. 
Co.La $|\mathrm{La} \cdot \mathrm{La} \cdot \mathrm{La}| \mathrm{Ly} \cdot \mathrm{Ly} \cdot \mathrm{Vi} \mid \mathrm{Flo} \cdot \mathrm{Tri}$, and num. berless others.

\section{Mesozeugma: See Zeugma.}

Metalepsis: The rhetorical figure of substituting a synonym for a word which is itself used in a metaphorical sense; thus, when, instead of speaking of 'black caverns' in the metaphorical or trans. terred sense of 'gloomy caverns', we speak of 'sable caverns'.

Metaphor: A similitude briefly expressed without any indication of comparison. In the latter feature it differs from Simile, in the case of which a com. parison is explicitly made in terms. Thus, 'the earth reeled like a drunken man' is a simile; 'after life's fitful fever' is a metaphor. Metaphors are of two kinds, viz. Radical, when a word or root of some general meaning is employed with reference to diverse objects on account of an idea of some similarity between them, just as the adjective 'dull' is used with reference to light, edged tools, polished surfaces, colours, sounds, pains, wits, and social functions; and Poetical, where a word of specialized use in a certain context is used in another context in which it is literally inappropriate, through some similarity in function or relation, as "the slings and arrows of outrageous fortune', where 'slings' and 'arrows', words of specialized meaning in the con. text of ballistics, are transferred to a context of fortune. The effect of the first process, tending, as it does, to reduce the number of names by bringing many particular meanıngs under a few general terms, is called Homonymy, or calling things by the same names; the effect of the second process, multiplying the number of special terms which may be used in foreign contexts, is termed Polyonymy, or calling things by many names. Nletaphors in which the similitude is not consistently adhered to, but abandoned halt-way in favour of annther simili. 
tude, are termed 'mixed' or 'broken', as 'to take arms against a sea of troubles'.

Metaphysical School: This school of poets owes its title to Johnson's statement in his Lives: 'About the beginning of the seventeenth century appeared a race of writers that may be termed the meta. physical poets', etc. It took its inspiration from the influence of John Donne (1573-1631), of whom Dryden said: 'Donne affects the metaphysics not only in his Satires, but in his amorous verses where Nature only should reign, and perplexes the minds of the fair sex with nice speculations of philosophy when he should engage their hearts and entertain them with the softnesses of love'. The peculiarity of this style was the exercise of 'wit', violent illustrations, comparisons, and allusions. 'But a yet more notable distinction of this school than its philosophizing shallow or deep is what may be called its fantasticality, its quaint wit, elaborate ingenuity, far-fetched allusiveness; and it might better be called the Ingenious or Fantastic School' (Ward). The taste was apparently in the air, and not originated by Donne, though Johnson suggests that he was himself influenced by Marini. Amengst those, however, usually classed in the school are Suckling, Denham, Herbert, Crashaw, Cleveland, and Cowley. The earlier poems of Milton, Waller, and Dryden also exhibit traces of the style.

Metaplasm : The grammatical term denoting generally any alteration in the structure of a word. This may occur by the processes either of addition, omission, or resolution. The names given to its specific forms are: Prosthesis, addition to the beginning; Epenthesis, insertion in the middle; Para. goge, addition at the end; Aphæresis, omission from the beginning; Syncope, omission from the middle; Apocope, omission from the end; Synæresis, contraction of the vowels: Antithesis, substitution of 


\section{1}

one letter for another; and Metathesis, the trans. position of letters.

Metastasis: The rhetorical figure meaning the converse of Commoratio (q.v.), in which the orator passes from one argument to another without dwelling long upon any.

Metathesis: See Metaplasm.

Metonymy: The rhetorical figure of the allusion to a feature or accessory of the object meant instead of to the object itself, as the use of 'the crown' for the royal prerogative, 'the sword' for armed violence.

Metre: Any verse scheme, quantitative or accentual, or stanzaic arrangement. The word bore a semitechnical meaning in classical prosody, equivalent in the case of some feet to dipody. See Dimeter, Trimeter.

Middle Comedy : See Old Comedy.

Middle Marcher, The: The alternative name given by Puttenham in the Art of English Poesy to the figure of Mesozeugma (q.v.).

Mimes: A species of literary composition made popu . lar by the Sicilian author Sophron about 440 B.C. The mime, so called because an 'imitation ' of reas life, was a peculiar species of drama written in prose, with no poetic form, reproducing scenes of common everyday occurrence, in fact, little realistic sketches They had a distinct influence on the Idylls of Theocritus, which is particularly exemplified in the fifteenth.

Mimiambics : Mimes (q.v.) written in iambics.

Mingle-Mangle, The : Puttenham's alternative term for Soraismus (q.v.).

Minnesinger (lit. 'singer of love', German): One of a class of German lyric poets and singers of the twelfth and thirteenth centuries, so called because love was their chief theme. They were almost exclu. sively men of noble descent, knights, princes, or even 
emperors, and they sang their pieces to their own a companiment on the viol. They flourished best in Suabia and Austria, and the dialect chiefly used was Suabian. Their classical representative is W'alther von der Vogelweider.

Minstrel: One of a class (introduced into England by the Norman Conquest) of men who for the amusement of the great sang bailads and romances to the accompaniment of their own harp or stringed instrument. There were originally two classes ot these: such as were the retainers of one particular noble, followed him to battle and shared in all his dangers and honours, and the more humble "jongleur", who served the multitude and travelled from fair to fair for a livelihood. This inferior class speedily assimilated itself to that of the Saxon gleemen. Put both classes sank in the social scale, and in $x \leq c 7$ minstrels were classed by statute with rogues and sturly beggars. In the tifteenth century they formed thenselves into guilds of itinerant musicians and mountelants. The superior class of minstrel often composed their own baliads, but their connection with the lumbler class ot mountebanks and ctrolling players was never torgotten.

Miracles or Miracle Plays: Scc Mysteries.

Misnamer, The: The alternative tutle bestowed by I'uttenham in his Art of Enslis't Peesy upon the figure of Metonymy (q.V.).

Muemonics: Sec Memoria Technica.

Mock-School: An alternative title bestowed by Hazlite on the Hieroglyphical School of IIriters (u.v.).

Mock-heroic: The species of literature which creates amusement by treating of lowly and commonplace matters in an extravagantly elevated and beroic vein. It is thus the converse of Burlesque (q.v.). Compositions of this sort have a very early origin; perhaps the earliest is the Batrackomyomachia, or 
Battle of the Frogs and Mice, which by some has been ascribed to Pigres, hrother of Artemisia, queen of Halicarnassus. It more probably is much later, and has been put as late as I60 B.c.

Moderator, The: The alternative title given by Puttenham in his Art of English Poesy' to the figure of Litotes (q.v.).

Molossus : The metrical foot consisting of three long syllables (- - ).

Monodrama: In strictness, a dramatic piece represented by one character only; sometimes applied to one involving two actors. Generally, a dramatic monologue.

Monody: An elegy or poem of mourning in which the mourner is supposed to hewail by himself, instead of in dialogue with others, as in Pastoral Elegy (q.v.).

Monologue: A play or poem purporting to be the utterance of one person only. It is sometimes used in the sense of Soliloquy (q.v.), but apparently incorrectly. It also means a play all parts in which are played by the same actor.

Monometer: A line consisting of a single 'metre' (q.v.). See Dimeter, Trimeter.

Monorhyme : A poetical composition in which every line ends in the same rhyme. The lines in $A s$ You Like It, 'If a hart do lack a hind', are an example.

Monostrophic : In prosody, a monostrophic composition is one consisting of a succession of strophes of identical structure.

Moralities : A morality was a variety of drama which evolved out of mysteries (q.v.) and gradually separated itself from them in the fourteenth century. It consisted of pious treatises and ethical discourses dramatized into allegorical representation, abstractions taking the place of individuals. There were elements of this nature, germs, as it were, of the 
murality, in mysteries as far back as the fourteenth century: Death, The Seven Deadly Sins, Mundus, etc., were represented in various collections; and the Middle Ages (witness the popularity of the Roman de la Rose in France and Piers Plowman in England) was intensely fond of allegory and symbol. Apart from being moral lessons, these plays were also usually amusing, the comic or farcical element being supplied by the Vice, who armed with a 'dagger of lath' acted as general buffoon, and gave rise to a tradition of the English stage which galled many a later playwright. Among moralities we may cite $A$ Goodly Enterlude of Nature, by Medwall (1538); Magnvyycence, by Skelton (r531); the Disobedient Child, by Ingelend (1550); a Comedye concerning Thre Lawes, by Ball (1538); the Triall of Treasure; Everyman, etc. The earliest English moralities are The Pride of Life and The Castle of Persecierance, both of which date from the fifteenth century.

Morbidezza : An Italian word signifying 'delicacy', used in connection with the art of painting to denote the treatment of flesh in all its natural softness and delicacy ; occasionally applied in a transferred sense to a delicate literary style or method of handling a subject with subtle light and shade.

Motet (Italian moto, a movement): A piece of church as opposed to secular music, from which the modern anthem is descended.

Mycterism: The rbetorical term for suppressed sneer. ing.

Mysteries: The drama in England sprang from religious sources, from liturgical action and antiphonal services, and the first step in its development therefrom was the mystery or miracle play, rude representations outside the church in the public place before it of stories either from the Bible (mysteries) or from the lives of the saints (miracles). 
The first of such performances of which we hear was at the beginning of the tenth century, when the story of S. Catherine was represented at Dunstable ; they attained the height of their popularity in the fourteenth century, and declined through the fifteenth to their death in the sixteenth. Written in doggerel and halting English, both rhyme and alliteration being used, and both anyhow, these plays soon became grouped in certain cycles: those connected with Old Testament history being played at the Christmas feast days; those dealing with the New Testament at the Easter festival, though later they were severed from these special occasions and performed at Whitsuntide and Corpus Christi, etc. The plays were usually performed by the trade guilds of the town: for example, the shipwrights would play the building of the ark; the fishermen would play the flood; the goldsmiths would impersonate the three kings with their crowns; and the vintners would, appropriately enough, be responsible for the miracle in Cana. There were also, however, special guilds, such as the guild of Corpus Christi and the guild of Pater Noster, established solely for the purposes of these performances. Churches and monasteries lent robes; the stage was generally a scaffold or sort of car (called a pageant); and there was frequently a separate one for each piece, these structures being ranged along the sides of the public square. They had generally two or more tiers, heaven being represented by the uppermost, while the lowest was generally a grisly and noisy bell, emitting many devils. 'The cycles of mysteries which have come down to us with more or less completeness are those performed at Chester, Coyentry, York, and Woodkirk (Touneley Mysteries). There are also many fragments. Niracles, as already explained, were plays of the same sort based on the lives of the saints; they were never popular in England, but enormous collections of those performed in France have been preserved. 
Mysticism : A mode of thought or phase of religious or intellectual life in which reliance is placed upon a spiritual illumination believed to transcend the ordinary powers of the understanding. "It appears in connection with the endeavour of the human mind to grasp the divine essence or the ultimate reality of things and to enjoy the blessedness of actual communication with the Highest '.

Myth: 'A traditional story in which the operations of natural forces and occurrences in human history are represented as the actions of individual living beings, especially of men, or of imaginary extra. human beings acting like men; a tale handed down from primitive times and in form historical, but in reality involving elements of early religious views, as respecting the origin of things, the powers of nature and their workings, the rise of institutions, the history of races and communicies'.

Namby-Pamby: A term denoting the sickly, senti. mental, or foolishly puling, especially in literature; so called after Ambrose Phillipps, a friend and contemporary of Addison, ' a good Whig and a middling poet, who had the honour of bringing into fashion a species of composition which has been called after his name Namby Pamby ' (Macaulay's Essays, ii).

Neck Verse: Condemned criminals who wished to avail themselves of benefit of clergy under $3 \mathrm{Ed}$. I were obliged to read a verse from the Psalter. The appropriate verse for the occasion was chosen by the bishop's Ordinary appointed by the bishop for the purpose at each prison. At Newgate it was Psalm $i, i$, 'Miserere mei, Deus': If the Ordinary passed the reading with the verdict 'Legit ut clericus' (be reads like a clerk), the criminal was branded in the hand in lieu of capital punishment, which he under. went if the verdict was adverse. There are numer. ous allusions to the practice in English literature. Cf. Massinger's Great Duke of Florence: 'How 


\section{7}

the fool stares. And looks as if he were Conning his neck-verse'.

Necrology : Originally, in religious houses, a list of the persons for whom prayer was to be offered; hence, an obituary or collection of obituaries. Roughly, any literature of the nature of 'bills of mortality'.

Nenia : See Posy.

Neoclassic: A term applied to any régime or school based upon reverence for and obedience to classical rules and models, with especial reference to the seventeenth and eighteenth centuries of French literature and literary criticism, which was for the most part based upon misinterpretations of Aristotle's Poetics.

Neologism: A word or expression coined direct, and not derived by the ordinary philological evolution or corruption.

Neoplatonism: A system of philosophical and religious doctrines which originated in Alexandria with Ammonius Saccas in the third century, and was developed by Plotinus, Porphyry, Iamblichus, Hypatia, Proclus, and others in the third, fourth, and fifth centuries. The system was composed of eiements of Platonism and Oriental beliefs, and in its later development was influenced by the philosophy of Philo, by Gnosticism and Christianity. Its leading representative was Plotinus, whose views were popularized by Porphyry, and infused with an element of mysticism by lamblichus. The last Neoplatonic schools were suppressed in the sixth century.

New Comedy : See Old Comedy.

New.Namer, The: Puttenham's alternative name for the figure of Unomatopœia (q.v.) in the Art of English Poesy.

Notitia: This word is sometimes used to denote the sum of human knowledge upon a certain subject, 
the body of information bearing upon such a subject, as, e.g. Votitia Eucharistica, the sum of information concerning the Eucbarist.

Novel: The novel may be briefly defined as a quasi. dramatic narrative of some action or passion forming a more or less artistically organic whole, and dealing with characters and circumstances (or, at any rate, a background) of everyday life. It is in respect of this latter qualification that the novel is said to be a peculiarly modern development, and it is in this respect that it differs from the romance proper, which is strictly concerned with adventures of a hero in spheres beyond the boundary of everyday life. There is, moreover, a difference in treatment between the novel and the romance: to the latter the adventures are the main thing; the former is concerned with the characters themselves, and not primarily with their adventures. It is in view of these two main distinctions that we usually say that the novel first appeared with Richardson's Pamela in 1740 . The literary origins, however, which contributed mainly to the rise of the modern novel were the characters or character-sketches (q.v.) of Hall, Overbury, etc., in the first half of the seventeenth century. These were followed by the Tatler and Spectator papers, which were little more than in. dividualized characters. To the element of realism in the novel the picaresque novel (q.v.) contributed, although itself strictly, according to the definition already laid down, belonging to the class of romance. With Richardson the novel began to assume its distinctively modern features, in spite of the clumsy and artificial method of narration in a series of letters, and the rise of sentiment in England and on the Continent stimulated interest in ethical and psychological writing. Pathos was developed to the maudlin point with such works as Mackenzie's Man of Feeling. This school was followed in suc. cession by the 'Gothic novel' (q.v.), the novel of 


\section{9}

theory (e.g. Godwin's Caleb Williams), the novel of domestic satire (Fanny Burney, Jane Austen, Maria Edgeworth), and Sir Walter Scott.

Novella: A kind of short story which became very popular in Italy from the fourteenth to the sixteenth century, and, reaching England in various transla. tions, exercised some influence upon the playwrights of the Elizabethan period, who frequently used them as material for their plots. The most important collection is, of course, the Decamerone of Boc. caccio (1313-75). Other novelli frequently rifled by the Elizabethan dramatists are those of Bandello (1480-1562) and Cinthio (1504-73), whose Gli Hecatommithi appeared in 1565 .

Occult School: The name given by Hazlitt in his essay On Criticism to the race of critics that 'dis. cern no beauties but what are concealed from superficial eyes, and overlook all that are obvious to the vulgar part of mankind. . . Nothing goes down with them but what is caviare to the multitude'.

Octave: A set or series of eight lines, con-tituting by reason of its rhyme-scheme a sort of whole in itself. Thus the Petrarchan sonnet is said to consist of an octave and a sestet.

Octonarius Versus : See Boiscius Versus.

Ocular Rhymes: Endings that rhyme to the eye, though not to the ear, as e.g. 'love', 'prove'; 'full', 'dull'; 'gave', 'have', etc. Ocular rhymes so called are generally admissible in poetry, but the criterion is, after all, the ear; and many endings which fulfil the conditions of the above definition are not rhymes, ccular or otherwise, and are cer. tainly not admissible, as e.g. 'cough', 'plough'. Ocular rhymes then may be said to consist of end. ings the written yowels of which are identical, while their pronunciation, though not identical, is not very dissimilar 
Ode: 'A lyric poem expressive of exalted or enthu. siastic emotion, especially one of complex or irregular nietrical form; originally and strictly such a composition intended to be sung'.

Oila Podrida : Literary odds and ends, stories, and anecdotes collected together without reference to any subject or plan. The term literally denotes in Spanish a pot-au-feu, or hotchpotch.

Old Comedy: A term applied for convenience to the earlier period of Greek comedy at Athens, which flourished from about 4 ;o to 390 B.C. It was political, or mainly so, and concerned with unsparing criticism of passing events, political and social, together with personal a use for all who appeared to deserve it in ary capacity, putslic or private. At the carnival of the Dionysia the poet had, as it were, carte blanche to speak his whole mind, and this licence, though on several occavions restrained by statute on account of its abuse, was undoubtedly a powerful political weapon which had considerable effect upon public opinion. It had a chorus of twenty-four persons, and one of its most distinctive features as apart from tragedy was the Parabasis (q.v.), in which the author spoke direct to the audience. The first name we have connected with Attic Comedy is Magnes. The great writers of this school were, however, Cratinus ( 43 B.C.), Crates (nearly contemporary with him), Eupolis (first play produced in 429 B.C.), and Aristophanes, the last and greatest, with whom the Old Comedy culninated and began to decline. It was followed by $\mathrm{w}$ hat is known as the Middle Comedy, a period of transition from political to purely social comedy, which lasted, roughly, from 390 to 320 B.C., and was occasioned by the gradual decay and final extinction of free political life at Athens. The old outspohenness became impossible: the element of choral music disappeared, including the parabasis, the chiefest instrument of criticism: and losing its bo!dness and bitterness, it turned to 


\section{1}

the discussion of literature and philosophy. Among its poets were Antiphanes, said to have written 260 pieces; Alexis, author of 245; and two sons of Aristophanes, Araros and Philippus. It was followed by what is known as the New Comedy, representing the last stage in the development of comedy at Atbens, which flourished from about 320 to 250 B.C. It now approximated more closely to what is known as the comedy of manners, having abandoned criticism, and concerning itself with certain stock characters, the stern or weak father, the young 'blood', the slave, the parasite, tbe martial swashbuckler, and their vicissitudes. This was the type of comedy imitated by the Roman dramatists Plautus and Terence; a fair idea of its character may be gathered from their pages. Its chief writers were Menander, Philemon and Diphilus, of whose works we possess next to nothing, although some quite recent finds have been made, it is understood, of Menander. It must always be remembered that these three species are merely consecutive stages in one gradual development, and by no means separate forms.

Onomatopœia : The formation of a name or word by an imitation of the sound associated with the thing or action designated, as 'tomtom', 'bomb', 'whistle', etc. The term is also applied to the word so formed, and in rhetoric to the grouping of words in sentences so as to suggest by their sound the thing described or referred to, as

' $I$ beard the ripple washing in the reeds, And the wild water lapping on the crag'

(Tennyson):

ar Virgil's 'Quadrupetante putrem sonitu quatit ungula campum'. According to one theory (nicknamed the 'Bow-wow' theory), this principle is regarded as the origin and basis of spoken language.

Opera: A sort of dramatic composition in whicb 
music is an essential and predominant factor. It began to be cultivated in France and Germany in about 1650 , and in England rather later, in which country it seems to have been directly connected in descent with the masque (q.v.). The modern opera involves the following distinct musical constituents : recitatives or musical declamations, mainly epic and dramatic in character; arias, duets, or trios; melodies for one, two, or three voices, usually lyrical; choruses and concerted numbers, in which the dramatic element usually predominates; and instrumental elements, including both accompaniments and independent passages, such as overtures, intermezzi, marches, dances, etc. The most elaborate type of opera is usually entitled Grand Opera.

Ordonnance: Order in literary composition; the orderly disposition of words, phrases, and sentences with reference to literary style. Dryden was the originator of this term.

Ottava Rima: A stanza form of Italian origin used by Tasso and Ariosto, and many others, particularly for the purpose of romantic narrative. It consists of eight decasyllabic lines, rhymed on three rhymes after the formula abababcc. It was the base of the Spenserian stanza. Keats's Isabella is written in this measure.

Oxymoron: The rhetorical term for the combination of words, generally epithet and subject, of opposed and contradictory meanings effecting a kind of verbal paradox, as e.g. Tennyson:-

' $\mathrm{H}$ is honour rooted in dishonour stood, And faith unfaithful kept him falsely true'. Also Horace, Odes: 'Splendide mendax'.

Pæan: A variety of Greek lyric in the form of a hymn imploring or praising the health-giving powes of the gods.

Pæon: The metrical foot consisting of three short 


\section{3}

syllables and one long. There are four varieties of pæon, differing from each other in the position of the long syllable, viz. $P$. primus, $-\smile \cup \checkmark$; secundus,

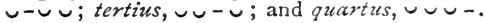

Pageant: A form of entertainment which had a genesis somewhat similar to that of the masque (q.v.). Of Italian origin, it took its rise in the Florentine $\operatorname{trionfi}$ (q.v.), processions of masked figures on foot or on decorated chariots representative of allegorical personifications. These trionfi themselves probably arose or developed out of liturgical processions of the Church. The English pageant doubtless owed much to these, but it had a native ancestry in the city pageants which were performed by the city guilds as early as 1236 . These in their turn were said to have been in. troduced from the Netherlands; but however this may be, they were not literary, and consisted of merely spectacular processions similar to the "Lord Mayor's Show', the subject of each being confined to the trades of the various guilds. Later, however, under the influence, possibly, of the trion $f$, , or owing to the reflected glory of the fashionable masque, the pageant in England towards the end of the sixteenth century became literary. City pageants were written by Middleton and Dekker. The pageant differed from the masque in being an out-ofdoor performance and consisting mainly of a procession. Part of Shirley's Triumph of Peace was a pageant, and passed in procession from Ely House to Whitehall. Of recent years there has been a revival of the pageant in many parts of England. The modern form is that of a series of scenes or dramatic episodes illustrative of the history of the town or locality in which it is performed. The scenario is generally the grounds of an old abbey or historical site, and an important element of the performance is the spectacular grouping and arrangement of processions or bands in appropriate costume. 
The term pageant' is derived from the Greek $\pi \hat{\eta} \gamma \mu a$ (Latin pagina), a structure, in which sense it was applied to the movable stages employed in the representation of mysteries. From this use of the word it probably received its spectacular sense.

Palillogy; The rhetorical figure of the repetition of a word or phrase for the sake of emphasis or impressiveness, as 'A steed, a steed, of matchless speed'.

Palimpsest: A parchment or vellum manuscript the original writing upon which has been rubbed off with pumice in order to make place for further writing. The result is therefore that not infrequently manuscripts have been found of comparatively worthless or unimportant works written over faint traces of far more valuable writings. These traces have been sometimes made legible by chemical means with very fortunate results.

Palindrome (Greek $\pi a \lambda i \nu \delta \rho o u o s$, running back. wards and forwards): A word or sentence the letters of which read either way the same, as 'ala', 'robor'. There is also another form consisting of a word or sentence which read backwards means something different, as 'Patrum dicta probo nec sacris belligerabo', a bexameter the words of which read backward make a pentameter of the converse meaning. The palindrome is said to have been invented by the Roman poet Sotades (c. 250 B.C.). All the Greek examples are modern. There is a colossal Greek example in a poem entitled П $\delta\llcorner\eta \mu a \mathrm{~K} a \rho \kappa \iota \nu l \kappa \iota 0 \nu$, by Ambrose Hieromonarchus Pamperes, and con. sisting of 416 lines, each of which is a palindrome.

Palinode: A poem expressing a recantation, as e.g. that of Stesichorus to Helen, after, as the legend goes, he had been struck blind for singing evil of ber.

Palliata: See Fabula Palliata. 
Pamphlet: A tract or monograph issued in the form of a thin paper-covered book.

Pantisocracy: The scheme advocated by Southey. Coleridge, and Lovell about 1794 of establishing an ideal utopian community on the banks of the Susquehanna, in which all the members would be equal in rank and social position and take an equal share in control.

Pantomime: An actor who expresses his meaning entirely by facial change and by gesticulation in dumb show. Under the Roman Empire the term was also applied to a sort of spectacular ballet in which the actors were restricted to dancing and dumb show while the text was sung by a chorus, with little if any dialogue. In its modern use it denotes a particular sort of Christmas dramatic performance, originally for children, consisting of two parts, the first a sort of piay founded on some fable or nursery tale, the latter, or harlequinade, merely a series of tricks, romps, and dances performed by harlequin, columbine, clown, and panta. loon.

Pantoum: A poem of fixed form consisting of quatrains rhymed after the formula abab. The first half of each quatrain should contain a different thought from that contained in the latter half, while the second and fourth line of each stanza must be the first and third of the following.

Parabasis: A curious feature of the Old Attic Comedy was the parabasis. At a point in the play where the action paused, the chorus, wheeling aside from their normal position, came forward towards the audience, and delivered to them direct a series of lyrics and addresses concerning topics of the day, constituting a sort of interlude. This was the 'parabasis', which means 'a turning aside'; its latter part was antistrophical, and during its delivery the chorus separated into halves which faced each other. It contained the personal views of the poet 


\section{6}

concerning political questions and social grievances, and was couched in terms of unsparing audacity; bence as the times grew less outspoken the parabasis was frequently omitted. It was probably delivered in recitative.

\section{Parable: Sec Allegory.}

Parachronism: The term given to a particular type of Anachronism (q.v) in its general sense, consisting of the introduction into a scene or background of any given period of something which had ceased to exist before that time, and which could never there. fore have coexisted with the other things represented as coexistent with it.

Paradiastole: The rhetorical figure in which a favour. able aspect is given to an unfavourable fact or argument by the use of language that conveys only part of the truth: "dilating or enlarging of a matter by interpretation'.

Paradigma: "A manner of withdrawing or exhorting by example, as to say: "the nature of the dolphin is not to suffer the young one of her kind to straggle undefended "' (A. Day, Eng. Secretary).

Paradoxon: The method of expression of things marvellous with words denoting the surprise and wonder of the speaker. Cf. Puttenham's example: 'I wonder nuch to see so many busbands thrive', etc.

Parænetics: Verses or compositions of a hortatory nature, full of precepts and admonitions.

Paragoge: Sce Metaplasm.

Paraleipsis: The rhetorical term for the avowed and intentional suppression of details with the object of exciting the emotions of reader or auditor.

Paralepsis: The rhetorical figure in which a charge or allegation is made by the very act of affecting to disregard or pass it over, the usual method of insinua. tion. 
Paraphrase: In the terminology of rhetoric, a version or recapitulation of a passage or work in easier and simpler language. In common parlance, the word merely means a version of some passage or work in a different form of language.

Para Prosdokian (lit. 'contrary to expectation'; Greek): A figure of speech in which a sentence end's in a way different from what the reader has been led to expect, a favourite form of joke with Aristophanes.

Parasiopesis: Affected reticence, implying what is meant.

Parathesis: The printed matter contained within brackets.

Parecbasis: The Greek rhetorical term for a digres. sion, the Latin digressio.

Parembole: Sce Paremptosis.

Paremptosis or Parembole: Alternative rhetorical terms for the insertion of a parenthetic paragraph in the middle of a sentence by way of a passing explanation.

Parenthesis: The signs in printing commonly called brackets, used to enclose words interpolated into a sentence without affecting its construction. The matter so interpolated is called Parathesis (q.v.).

Parenthyrson: A phrase used by the rhetor Theodorus to denote the literary vice of 'enthusiasm' out of place, unseasonable bombast or elevation of style.

Parian Verse: Satires written in Greek iambic metre ; so called after Archilochus of Paros (670 B.c.), the creator of this class of literature. The earliest employment of iambics was in satire.

Parison: The exact balance of clauses in a sentence, generally for antithetical effect.

Parimion: See Like Letter.

Parnassiens: The title usually given to a school of 
French poets founded by Xavier de Ricard and Catulle Mendès on the basis of admiration for Theophile Gautier, Leconte de Lisle, Baudelaire, and Banville. The name was derived from $L e$ Parnasse Contemporain, an anthology (the first part of which was published in 1866), containing the work of a large number of romantic poets, some previously unknown, who flocked to its standard. The school included, in addition to those mentioned above, de Heredia, Ménard, François Coppée, Sully Prudhomme, Verlaine, Houssaye, Mallarmé, and many others. The Parnassiens are, however, less a school of any definite tendency or tradition than a group.

Parnassus: The mountain-home of the Muscs, sometimes applied to a collection of poems.

Parodos: The first song or choral ode sung by the whole chorus in Greek drama on the occasion of its first entry into the orchestra, which generally took place immediately after the prologue. It was sometimes accompanied by dancing, sometimes not.

Parody: A burlesque or travesty of some literary composition, imitated closely in form, style, and matter with the purpose of ridicule. The word is derived from the Greek $\pi \alpha \rho \omega \delta i a$, a burlesque, of which class of writing Aristotle says Hegemon of Thasos was the inventor. An early specimen of parody in the modern sense is the mock.Homeric Batrachomyomachia, or Battle of the Frogs and Mice, ascribed to Pigres, brother of Artemisia of Halicarnassus, but probably much later. Of famous modern parody-writers may be mentioned Calverley and Owen Seaman.

Parœmiac Verse: An anapæstic dimeter catalectic, Uu - U - Uu - $\tau$; so called because suitable for proverbial sayings; it is frequently used in Greek lyric poetry either to close a passage of anapæests or singly among other rhythms. 
Parolist : A user of affected words.

Paromologia: The rhetorical figure in which some. thing is conceded to an adversary in order to strengthen one's position. 'I grant that they are resolute, but to their own undoing'.

Paronomasia: The rhetorical term for a play upon words, or punning; the use of a word in more than one sense in the same passage, or the contrasting of different words with identical or similar pronuncia. tion. Cf. Hood :-

'They went and told the sexton

And the sexton tolled the bell'.

Paronymous: Derived from the same root, as the words 'entire', 'entirely', 'entirety'.

Parrhesia: The rhetorical figure of bespeaking par. don beforehand for any unusually outspoken state. ment meditated.

\section{Parthenia: See Prosodia.}

Partures: Another term for the jeux partis of the more northerly parts of France, called tensons in Provence.

Pasquinade: A lampoon or piece of violent satire. The story of the origin of the term is as follows: There was a tailor at Rome named Pasquin, whose satirical wit was well known, his bons mots passing current through the city under the name of Pasquinades. He died; and soon after a marble statue was unearthed under the pavement before his shop, which by general consent was christened Pasquin or Pasquil. Thereafter it became the practice, in the state of despotism which prevailed, for lampoons to be affixed under cover of night to this statue and another named Marforio, purporting to be the utter. ances or the conversation of these two. A book containing many of these satirical pieces, both in prose and verse, was published at Basle in 1544, entitled Pasquillorum Tomi Duo, which is ex- 
tremely rare, owing to the partly successful attempts of the papal government to suppress it. The method of satire by dialogue was early introduced into England; in 1589 was published "The return of the renowned Cavaliero Pasquill to England from the other side of the seas, and his meeting with Marforio at London, upon the Royal Exchange '. References to Pasquil are also found in the course of the Martin Marprelate controversy.

Passager, The: Puttenham's alternative Englisb term for the figure of Paralepsis (q.v.).

Passion Play: A species of mystery (q.v.) dealing with scenes or incidents from the Passion of Christ. That still performed every ten years at Ober Ammer. gau, in the Bavarian highlands, is perhaps the best known, and, indeed, the only example still repre. sented.

Pastiche: The word pastiche (French), the Italian pasticcio, is originally a term of painting. In con. nection with literature it denotes two things: either a composition in which the author has merely striven to approximate as closely as possible to the ideas and style of some great author, an obvious imitation, though without the intention of parody ; or an opera composed of scraps of music already written for some other purpose patched together to suit a new libretto; a medley.

Pastoral: A composition dealing with rustic life, either of the artificial type of the conventional Arcadia, or otherwise. The style was popularized in England at the beginning of the seventeenth century, and derives its origin through Virgil's Bucolics and Sannazaro's Arcadia, from Theocritus, and his imitators Bion and Moschus.

Pastoral Elegy: An elegy or poem of mourning set in the mise en scine of the conventional arcadia, and cast in the form, either partially or wholly, of pas. toral dialogue between conventional shepherds. 
Examples of this style of poetry, which was derived through Virgil, from Theocritus, Bion, and Moschus, are Milton's Lycidas, Shelley's Adonais, Ar. nold's Thyrsis, and Spenser's Daphnaida.

Pastoral Romance: A species of romance which came in to vogue in the sixteenth century compounded of the amours and adventures of the usual chivalric romance in a setting of conventional rusticity. It originated with Montemayor's Diana Enamorada (1542), and was imitated by the Astrée of D'Urfé, Sidney's Arcadia, etc.

Patavinity : Quintilian refers in his criticism of the historian Livy to that writer's 'Patavinitas', viz. the traces in his style of provincial idiom and diction peculiar to the town of Patavium or Padua, of which he was a native. No one has decisively or even definitely pointed out the nature of this peculiarity, which, as one may readily understand, is probably of too subtle and intangible a character to be appreciated by any save those to whom Latin was a living language. The term Patavinity is generally applied, however, to any instance of unintentional provincialism, in a style purporting to be correct and literary.

Pathetic Fallacy: The term given in condemnation by Ruskin in his Modern Painters (III, iv, xii) to the literary practice of referring to inanimate objects as though they were possessed of passions and emotions. He says: 'All violent feelings . . . produce .... a falseness . . in impressions of external things which I would gladly characterise as the "Pathetic Fallacy "', and an example singled out for chastisement is Kingsley's Sands of Dee, in the course of which occurs the expression "The cruel crawling foam, the cruel hungry foam'. The obvious reply to this criticism is that to read human or animate emotions into inanimate objects of external nature under stress of personal emotion is the commonest thing in life, either in or out of poetry, and based 


\section{2}

deep down in the 'anthropocentric' tendency of mankind. Moreover, it is a practice of all great poets, and gives rise in many cases to extreme beauty and pathos, because natural.

Pauses: A term occasionally applied to enterludes (q.v.), acted in France in the intervals between the mysteries. The derivation is obvious.

Pentameter: The pentameter line is as follows:

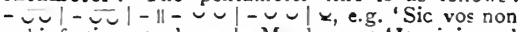
vobis fertis aratra boves'. Munk says: "It originated in the heroic hexameter, inasmuch as the thesis of the third and sixth foot is occupied by a pause; hence the diæresis (or cæsura) after the third arsis is necessary. As it therefore consists of twice two and a half dactylic feet, it was called the pentameter' (line of five feet). It should be noted that in the above passage arsis is used in the now discarded sense of 'accented foot'. Its chief use is in the elegiac couplet (q.v.). It is seldom used by itself, except with a slightly comic effect, as e.g. in Virgil's epigram, from which the example above is quoted.

Penthemimeral: The cæsura of a hexameter line is said to be penthemimeral when it comes immediately after the first five balf-feet, i.e. after the first half of the third foot, as 'Arma vi| rumque ca | no || Tro | je qui | primus ab|oris'. See also Hephthemi. meral.

Penult: The last syllable but one of a word.

Pericope: A term of classical prosody denoting a series of strophes of two or more varieties of structure.

Periergia: A bombastic or laboured style: 'overmuch curiosity and study to show himself fine in a light matter' (Puttenham).

Periodic Style: A literary style in which the periods, or clauses, are ordered in close and regular interdependence; locked together, as it were, by grammatical construction. It is opposed to a 'loose' style 
in which the sentences are strung together more loosely. Gibbon may be cited as an example of the: first ; Stevenson or De Quincey of the second.

Peripetia : Peripetia, or, as the word is generally translated, 'Reversal of Fortune', is a part of the Aristotelian theory of tragedy laid down in the Poetics. Its place is assigned to it as one of the ingredients in a 'complicated ' plot which assist in carrying on the action to the central situation or turning-point of the play. It is defined as "the change by which a train of action produces the opposite of the effect intended; and that, too, according to our rule of probability or necessity: as in the Edipus, when the messenger, hoping to cheer Edipus and to set his mind at rest concerning his mother, reveals his origin, and so produces the opposite effect.'

Periphrasis: The rhetorical term for the circuitous and indirect method of allusion to some object which for reasons of decency or effect it is not desirable to refer to directly.

Petrarch, School of : See School of Petrarch.

Phalæcean or Phaleucian Verse: The classical metre usually termed 'hendecasyllables', as 'Lūgěte, ôvěnĕrēs cŭpidinēsque ' ; ' $\overline{\mathrm{O} h}$, yōu chōrŭs ŏf îndŏlēnt rěviewĕrs'.

Phébus: A cant word in French literary criticism approximating nearly to the meaning of our term 'high-falutin'.

Pherecratean Verse: A line consisting of a dactyl between two trochees or spondees, as "E $\mathrm{\lambda} \delta \check{\epsilon} a i$ $\phi \bar{i} \lambda o \nu \overline{\hat{\eta}} \tau o$ $\rho$. It is a species of irrational dactylic or logaœdic verse, so called because its rhythm partakes of the nature of the rhythm of ordinary speech. It frequently occurs in Greek lyric or 


\section{4}

dramatic poetry, either singly, repeated, or in con. nection with other rhythms.

Philistinism: The lack of any sympathy with literature and the fine arts, and of any appreciation of them, a lack of culture coupled with a self-satis. faction unconscious of its deficiency. 'Philistinism, that plant of essentially Germanic growth, flourishing with its genuine marks only in the German fatherland, Great Britain and her colonies, and the United States of America ' (M. Arnold).

Phlyacography: Another term for a Hilarotragedy (q.v.).

Phonogram: See Logogram.

Physiologi: Series of writings of a devotional nature illustrating the duiles of Christians from the supposed abits of animals. They have been found in nearly all the languages of Europe, and in Syriac, Arabic, Ethiopian, etc. The original appears to have been composed at Alexandria, in Greek, in the second century A.D. They gave rise to and were succeeded by the bestiaries (q.v.).

Picaresque: A picaresque novel or picaresque litera. ture is that which deals with the adventures of a clever and amusing rogue represented in a sym. pathetic light. The term, and indeed the class of work itself, originated in Spain with the novelas de picaros, or novels about rogues, the first and most important of which was the Life of Lazarillo de Tormes (1554) by Mendoza, continued in a sequel by Luna in 1620, and followed by Guzman de Alfarache (1599) by Mathew Aleman, Life of Buscon or The Great Knave by Quevedo (1626), Nash's Jack W'ilton, Le Sage's Diable Boiteux and Gil Blas, Defoe's . Holl Flanders, Colonel Jack, etc.

Pièce de Circonstances: A dramatic composition suggested or inspired by passing events.

Pindaric or Pindaric Ode: A term applied by their contemporaries to the odes of Cowley and his 
imitators, who thought to catch the inspired freedom of. Pindar by the use of mere meirical irregularity. Pindar, of course, in spite of the soaring liberty of his compositions, was not in the least metrically irregular.

Pindarism : This term is used in two different senses; one by Dr. Johnson of the loose and irregular structure of the poems of Cowley and his imitators which was thought to be a feature of the odes of Pindar; the other by Matthew Arnold: 'A sort of intóxication of style-a Pindarism, to use a word formed from the name of the poet on whom, above all other poets, the power of style seems to have exercised an inspiring and intoxicating effect ' (Study of Celtic Lit.).

Plagiary or Plagiarist: An author who borrows ideas or language from others without assimilating them to his own purpose and transmuting them by his own personality. The fact of borrowing alone does not constitute plagiarism; many great authors have been deeply indebted to others without incurring the charge, as, for instance, Milton, whose Comus was distinctly influenced both by Fletcher's Faithful Shepherdess and Browne's Britannia's Pastorals. A true plagiarism, however, is like a new patch upon an old garment, or in the words of Puff in The Critic: 'the finest passages ... lie on the surface like lumps of marl on a barren moor, encumbering what it is not in their power to fertilize'.

Planh : The species of Provençal poetry consisting of a lament or sort of elegy, such as that of Gaucelm Faidit on the death of Richard Cœur de Lion. See Saber, El Gai.

Planipedes: Actors of Latin mimes; lit. 'flat. footed', because they wore neither cothurnus nor soccus.

Pléiade, The: The name qiven by the French poet 


\section{6}

Ronsard to the constellation of seven poetical stars which constituted his school and exercised an im. portant influence on French literature. It com. prised Ronsard himself ( $1524-85)$, Joachim du Bellay (1524-60), Jean Dorat (1508-88), Jean Antoine de Baif (1532-89), Estienne Jodelle (r532-73), Pontus de Thyard (1521-1605), and Remy Belleau (1528-77). To these are sometimes added Olivier de Magny, Amadis Jamyn, Robert Garnier, Passerat, Desportes, etc. Their object was to reform the French language and literature, the former by the wholesale introduction of neologisms culled from the classics, the latter by the close imitation of classical forms and style. Reform was indeed necessary, for the school of Marot was losing its inspiration, and had sunk to the level of puerile triflings with ballade and rondeau. From these épiceries the Pléiade called men's attention to the great models of Greece and Rome in its famous manifesto written by du Bellay and published in 1543 , Deffense et Illustra. tion de la Langue Franfaise.

Pleonasm: Redundancy of language, the use of more words than are necessary to express an idea, justifi. able if particular perspicuity is required.

Ploce: The rhetorical figure of the repetition of a word one or more times in close succession, especially with a change of meaning or application.

\section{Poet Laureate : See Laureate.}

Poetic Moment, The: A phrase coined by Prof. Saintsbury to express a theory contrary to that of what he calls the 'Poetic Subject'. According to the doctrine of the Poetic Subject, poetry is to be valued according to its "high seriousness'; that is to say, a poem should be judged according to the greater or the less elevation of its subject-matter and the loftiness and breadth of its moral outlook upon life. According to the doctrine of the Poetic Moment, however the essence of poetry is the 
'sudden transcendence and transfiguration' which sits upon a phrase or idea; and inasmuch as this poetical splendour does not admit of qualitative comparison, that poetry which contains most 'poetic moments ' is the best.

Political Criticism: The name given by Hazlitt, in his essay On Criticism, to the type of criticism, in his time quite usual, which praised or condemned according to the political views or party of the author. 'It is not a question of literary discussion, but of political proscription. It is a mark of loyalty and patriotism to extend no quarter to those of the opposite party. Instead of replying to your arguments, they call you names, put words and opinions in your mouth which you have never uttered, and consider it a species of misprision of treason to admit that a Whig author knows anything of common sense or English'.

Polyhymnia: The Muse of the inspired religious hymn or invocation; often referred to in the specific sense of that class of literature.

Polyonymy: See Metaphor.

Polyptoton: A term of Latin and Greek syntax to denote the figure by which different cases of the same noun are brought together, as e.g. 'Jam clipeus clipeis, umbone repellitur umbo'.

Pornographic: A term applied to literature or art dealing with obscene sexual relations.

Portmanteau: The term invented by Lewis Carroll in Alice in Wonderland to designate a word com. posed of two words telescoped, as it were, into one, and so combining two meanings, as e.g. 'slithy', a portmanteau of 'lithe', and 'slimy'; 'frumious', meaning both 'fuming' and 'furious'. The abovementioned book perhaps acted as a stimulus upon the production of portmanteaus. We have all heard of the useful word 'brunch', used to denote the late 1 iser's meal which is both breakfast and lunch, 
while not a few of us are familiar with the word 'nonscience', coined to supply' the place of the cumbrous phrase 'Nonconformist conscience'. It should be remembered, however, that while Lewis Carroll was the author of the name, the thing itself was known before him. Bishop Wilberforce perpe. trated a portmanteau when he alluded to a parson with a con-iderable element of the squire in him as a "squarson'. There is also upon record the allusion of a nameless Irish cleric to the "imper. furities' of monki id.

Port-Royal: A religious house in Paris which became of great importance in the seventeenth and eighteenth centuries. Its teaching was based on hostility towards methods of Jesuit casuistry, and especial attention to the Scriptures themselves and the writings of the Fathers, particularly S. Augustine. It was also a stronghold of "Jansenism", the 'heresy' of Bishop Jansen, which may be roughly described as a reaction against Jesuitism combined with 'a revival of the Augustinian tenets upon the inability of the fallen will and upon efficacious grace'. Their importance for literature rests, how. ever, in the fact that the Port-Royalists exalted the dignity of education, maintained schools, and wrote school books in the spirit of the Cartesian philosophy. Among its most distinguished mem. bers Port-Royal included Rlaise Pascal (1623-62), author of the famous Lettres Provinciales; Arnauld $\left(1597^{-1604}\right)$, the polemical writer of the associa. tion: Pierre Nicolle, author of the Essai de Morales; Lemaitre de Sassy, etc.

Posy : The term applied by the Elizabethans to any short motto or epigrammatic verse, when used motto-fashion. Puttenham says, in the Art of Eng. lish Poesy: "They were called Nenia or Apophoreta, and never contained above one verse, or two at the most, but the shorter the better; we call them Posies, and do paint them now a days upon the 


\section{9}

back sides of our fruit trenchers of wood, or use them as devices in rings and arms and about such courtly purposes '. Their nature may be sufficiently indicated by two examples from betrothal rings: 'In thee I find Content of mind'; and 'God did foresee We should agree'. The word is, of course, a contraction of 'poesy'.

Poulter's Measure: A couplet of which the first line is an alexandrine, and the second a fourteener or line of fourteen syllables, as-

'So feeble is the thread that doth the burden stay

Of my poor life in heavy light that falleth in decay'. It was popularized by Wyatt and Surrey.

Prætextatæ: See Fabula Prætextata.

Pragmatographia : According to Puttenham, writing descriptive of action or human activity of any sort.

Praxilleus Versus: This measure is a line of three dactyls followed by two trochees, - $\checkmark-\cup \checkmark-\smile \cup-$ $\checkmark-\Xi$.

Preciosity: Absurd over-refinement or delicacy of taste; the pedantry, not of accuracy or knowledge, but of affected culture.

Preposterous, The: The alternative title given by Puttenham in the Art of English Poesy to the figure of Hysteron Proteron (q.v.).

Priapeus Versus: A line consisting of a Glyconic followed by a Pherecratean (q.v.), - $\checkmark \checkmark-\cup--$

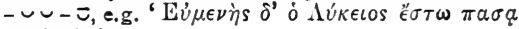

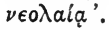

Privy Nip, The: Puttenham's alternative English name for the figure of Charientismus (q.v.).

Problem Play: The so-called problem play is one which deals with and represents situations and questions arising out of the relations between the sexes, nominally ' with a purpose' either didactic or 


\section{0}

philosophical. The name is derived from the fact that such plays purport to put before the audience some problem of social or sexual conditions, a characteristic which in many cases merely succeeds in contributing a note of morbidity to the play.

Procatalectic : A verse or line of poetry is said to be procatalectic when a syllable is wanting from its first foot, that foot being incomplete. Such a line differs from one that is catalectic(q.v.); the deficiency in the latter variety coming always in the last foot.

Procatalepsis: The rhetorical figure in which the speaker or writer anticipates his opponent's argu. ments.

Procatastasis: The rhetorical term denoting the 'introduction to narrative ' in a speech.

Proceleusmatic: In prosody a foot consisting of four short syllables $(\checkmark \smile \cup \cup)$. The word means relating to excitement, animating, encouraging. A proceleusmatic song was one sung or played to the oarsmen in a galley, to make them keep good time and urge on their labours.

Prodelision: A variety of elision (q.v.) peculiar to Greek prosody, consisting of the cutting out of the second vowel-sound in a hiatus, whereas elision proper is the cutting out of the first; e.g. Aristoph ,

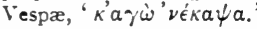

Prodiegesis: The rhetorical term signifying the "pre. liminary statement ' in a speech.

Prolepsis: The rhetorical figure of the anticipation by a speaker or writer of his adversary's arguments for the purpose of refuting or discounting them; also called Procatalepsis.

Proleptic: The rhetorical term applied to the use of words in an anticipatory sense, as Eugene Aram'Anon I cleansed my bloody hands, And washed my forehead cool - 
where 'cool' is used proleptically, his forehead not being cool until it had been washed. There is also an historical use of the word, as e.g. a reference to the Duke of Wellington at Assaye, he not having teen created Duke of Wellington until later.

Prologue: The prologue was originally that part of a Greek play which preceded the first chorus; but as this part frequently consisted of a speech by a herald or one of the characters, in explanation or adumbration of the story about to be represented, the word took on the meaning of a sort of preface, sometimes addressed by the author or an actor direct to the audience, in other cases as a kind of explanatory monologue delivered by one of the characters.

Proode: The term applied in Greek prosody to the first line ot a distich, the last being termed the Epode.

Prooem : Preface, introduction.

Prophecy, Literary: A prophecy, the fulfilment of which is known to the readel as a matter of history, in the mouth of some character of fiction. A wellknown example is the lines in Southey's Boadicea, beginnıng 'Regions Cæsar never knew', etc.

Propounder, The: The alternative title given by Puttenham in the Art of English Poesy to the figure of Prolepsis (q.v.).

Prose and Reason, Age of : Sec Age ot Prose and Reason.

Proses or Prosæ: This term denoted Latin hymns, rhyming and accentual, which, after the end of the ninth century, were sung in the Roman Church after the Gradual. They were also called Sequentia.

Prosodia: A class of hymn written by Aicman of Sparta ( 660 B.c.) to be sung during processions to temples. Those to be sung by maidens were termed Parthenia. 
Prosopopca: The rbetorical term for an address to or invocation of inanimate objects as though they could hear and understand, e.g. Burns's 'Ie banks and braes of bonny Doon', etc.

Prosthesis: See Metaplasm.

Prosyllogism: A preliminary syllogism; one necessary to the proof of another syllogism. The word is also used, however, in the sense of Enthymeme (q.v.).

Frotagonist: The first or principal actor in Greek drama. His position was, however, of greater im. portance than even this would suggest, for Greek tragedies were framed so as to bring out into strong relief the character of the hero of the piece, other characters being subordinated and made to act as foils to him. Hence the success of a play depended entirely upon the leading actor, who represented the central figure. As a matter of fact, in ordinary, as well as official parlance, the protagonist was said 'to act' the play, the other actors being ignored, and the acting competition was between prota. gonists only. The protagonist himself selected the other actors, there never being more than three inclusive. The others were obliged to refrain from any attempt to outshine their leader. In view of the small number of actors, they were all obliged to 'double', i.e. represent several parts, and the protagonist took those which required finest acting. See Deuteragonist and Tritagonist.

\section{Protasis: See Conditional Sentence.}

Prothalamium: This word has the same meaning as epithalamium (q.v.). It is the title of one of Spen. ser's poems, and occurs elsewhere, but not frequently.

Provence, School of : Sce School of Provence.

Prozeugma : See Zeugma.

Pseudepigraphy: The attribution of false names of authors to various works. 
Pseudonym: This term strictly denotes a false name assumed by a writer for literary purposes which, however, purports to be the correct name, as e.g. 'John Oliver Hobbes', the name under which Mrs. Craigie wrote. A name which, however, is obviously fanciful and does not purport to be a correct. name, as e.g. 'Boz' or 'Junius', is not strictly a pseudonym, but a form of anonymity.

Pun : A play upon words, consisting of the use of a word or phrase in a certain sense with direct or indirect reference to the sense of some other word or phrase of identical pronunciation :-

'They went and told the sexton,

And the sexton tolled the bell'.

Purist: One affecting the particular form of pedantry which excludes and objects to any vocabulary, style, or grammatical construction not in accordance with a strained and over-rigorous set of canons. It implies an accusation of unnecessary exactness.

Purple Patch or Passage: A term commonly applied in literary criticism to any occasional phrase, sentence, or passage of literary merit or brilliance rendered incongruous and obtrusive by the general low level and poor quality of the context. The phrase is derived from the well-known passage in Horace, Ars Poetica (1. 15) :-

$\because$ veniam petimusque damusque vicissim Sed non ut, etc.

Inceptis gravibus plerumque et magna professis

Purpureus late qui splendeat unus et alter Adsuitur pannus'.

Puy: A species of literary society of which many were founded in the fourteenth century of French literature. They maintained the rules of art and awarded crowns to successful competitors. The word 'puy' itself, meaning 'mountain' or 'emi. nence', denoted the elevated seat of the judges at the competitions. 


\section{4}

Pyrrhic: The metrical foot consisting of two short syllables $(\cup \cup)$ as 'dŭcě'; so called from its being used in the Pyrrbic war-song.

\section{Quadratus Versus : See Septenarius.}

Qualifier, The: The alternative name given by Puttenham in his Art of English Poesy to the figure of Epitheton; the practice of qualifying a substantive with an epitbet.

Quantity; See Accent.

Quasîda: A form of Arabian poetry consisting of a loosely connected ode in rhyme. It generally pre. serves a certain scheme, i.e. it commences with a sort of introduction concerning the forsaken camping-ground, and then proceeds to reflections on the singer's love affairs.

Quaternarius: A line of four feet.

Quatrain: A stanza of four rhymed lines; these may be rhymed in any fashion, but the scheme must always be complete in the quatrain itself. The word is sometimes applied, however, to a set of four lines forming part of a longer stanza-form, in which case the rhyme-scheme, as forming a series or part of some larger rhyme-scheme, need not be complete within the quatrain.

Quick Conceit, The Figure of: The alternative title given by Puttenham in his Art of English Poesy' to the figure of Synecdoche (q.v.).

Quinarius : A line of five feet.

Quintain or Quintil : In French prosody, a stanza of five lines, rhymed on two rhymes upon any scheme save aabbb or aaabb.

Quodlibet: The name given to the questions propounded by the schoolmen, which they proceeded to debate with hair-splitting logic and ludicrous refinements of definition. These dialectical niceties were often not far removed in absurdity from the parodies 


\section{5}

on them in Arbuthnot's Martinus Scriblerts, among which occurs the famous proposition 'How many angels can dance on the point of a very fine needle without jostling ?' A genuine quodlibet which was frequently debated as an exercise in dialectics is the following: "When a hog is carried to market with a rope round its neck which is held at the other end by a man, whether is the hog carried to market by the rope or by the man?'

Raisonnable, Tragédie : The term applied by critics of the neoclassic French school to a tragedy which conformed to the conventional rules, unities, etc.

Realism : The representation in literature and art of what is real in fact; the effort to exhibit the literal reality and unvarnished truth of things without selection over the ugly of what is beautiful or admirable. Very often, however, realism amounts to the deliberate selection of the ugly over the beautiful, and the emphasizing of the more painful side of nature, the seamy side of humanity. Among the apostles of realism may be mentioned Zola in France and Gogol in Russia.

Rear-Warder, The: The alternative name given by Puttenham in the Art of English Poesy to the figure of Hypozeugma (q.v.).

Rebus: The representation of a word by pictorial signs, as an eye and a tun to denote Eyton. It is frequently used in heraldry, and also as a species of riddle.

Recompenser, The: The English name given by Puttenham in his Art of English Poesy to the rhetorical figure of Antanagoge (q.v.).

Recto: In paging manuscripts it was and is still customary to number, not the page or side of matter, but the leaf or folio. Each folio receives a single number, while its front side, called the Recto, is distinguished as ' $a$ ', and the hinder side, termed 


\section{6}

the Verso, as ' $b$ '. The lettering is often, however, not employed. The system is due to the original state of MSS. in separate sheets or rolls, but it is applied to MSS. bound in book form also. In such cases the Recto is the right-hand page, the Verso the left-hand page on turning over.

Redondilla: The earliest Spanish metre, consisting of lines of four trochaic feet. It was the medium of the most ancient Castilian, Portuguese, and Galician poetry, and though many theories of its origin have been propounded (among others, that it consists of a series of half-hexameters), the most likely suggestion is that it is descended from the songs of the Roman soldiery, several of which, preserved by Suetonius, have a distinct resemblance to this measure. 'The characteristic rhythm is that of the ballad 'Rioverde, rioverde', given in Percy's Reliques. If we compare with this such Latin bymns as Dies Irce, the similarity at once becomes apparent. The name itself is derived from the Spanish redondo, 'round'; indeed, reciondilla is often translated 'roundelay'. These trochaic lines are usually grouped in quatrains.

Religious Nouvellettes: The title given by d'Israeli in his Curiosities of Literature to a class of pub. lication which sprang up in the fifteenth century and had a considerable vogue in the sixteenth and seventeenth. They consisted of narratives of Bible stories or commentaries upon the dogmas of Chris. tianity infused with a spirit of romance and gal. lantry, and generally accompanied by licentious or obscene details. Such a book was published in 1500 , entitled Hortulus Anima, and consisting of prayers accompanied by 'figures', either ridiculous or in. decent. There was also a Dévote Salutation des Membres sacres du Corps de la Glorieuse Vierge, Mere de Dieu, published at Paris in 1668 ; the Life of the Virgin of Maria Agreda, a highly imaginary and romantic narrative; the Empyreologia of a 


\section{7}

Spanish Jesuit, published in 1652 , which professes to give a complete account of the joys of heaven in store for the faithful; and numberless other works of a similar character and tendency.

Remove, Figure of: Puttenham's alternative Eng. lish term for Metastasis (q.v.).

Remplissage : Literary padding.

Renaissance: A general term denoting the transition in Europe from the mediæval to the modern world especially with reference to the spirit and activity of the revival of classical arts and letters. The earliest traces of the movement are to be found in Italy, where Petrarch and the early humanists may in a sense be regarded as its precursors, but it was greatly stimulated by the taking of Constantinople by the Turks in $r^{4} 53$ and the consequent exodus of Byzantine scholars who swarmed into Italy and established schools. Contributory also to the development of the Renaissance and of its peculiar attitude to life were the new discoveries in exploration and the consequent opening of new lands and new wonders. The invention of printing, moreover, assisted the diffusion of knowledge, and that of gunpowder revolutionized the art of warfare. The revival of learning in England may be said to have commenced about 1500 , and was fostered by Erasmus, Colet, Grocyn, More, etc.

Renascence of Wonder: A term coined by Mr. Watts-Dunton in his Introduction to Aylwin to express an aspect of the Romantic Revival. He wrote: "The phrase, the Renascence of Wonder, merely indicates that there are two great impulses governing man, and probably not man only, but the entire world of conscious life: the impulse of acceptance-the impulse to take unchallenged and for granted all the phenomena of the outer world as they are-and the impulse to confront these phenomena with eyes of inquiry and wonder ". Accord. ing to this view the latter was the attitude of the 


\section{8}

pre-Augustans in England, who expressed not only 'wonder of the simply terrene kind', but also 'spiritual wonder... that kind of wonder which filled the souls of Spenser, of Marlowe, of Shake. speare, of Webster, of Ford, of Cyril Tourneur, and of the old ballads; that poetical attitude which the human mind assumes when confronting those unseen powers of the universe who, if they did not weave the web in which man finds himself entangled, dominate it'. With the Augustans that attitude gave place to 'a temper of prosaic acceptance', the opposite spirit; and the term is applied to the reaction from this towards the more truly poetical and spiritual attitude of wonder which constitutes one of the most vital elements of the revival.

Rentrement: The extra-metrical unrhymed refrain which follows the tercet and second quintain of a rondeau (q.v.). It always consists of the first few words of the first line.

Response. Figure of: Puttenham's alternative English term for Antapophora (q.v.).

Restoration Dramatists: A convenient term to denote the dramatists of the reign of Charles ii : D'Avenant, Wilson, Orrery, Crowne, Lee, Shadwell, Etheredge, Wycherley, Congreve, Otway, Vanbrugh, Behn, Centlivre, Southerne, Farquhar, and, of course, Dryden. The term is not as idle as many similar terms derived from historical events. The inspiration of the age was mannly guided by court fashion, and this was shaped and coloured by the sojourn of the exiled prince and his courtiers in France, and rendered extreme by the inevitable reaction against Puritanism.

Rhapsody: Originally in Greek, as applied to the Homeric poems, such a section of the text as was allotted for recitation to a single person, those recitations proceeding in concerted order. Hence a short epic poem or such part of a larger one as 
could be recited at one sitting. In its more moderp sense, however, the word denotes an extravagant flight of enthusiasm or a poetic composition of that character.

Rhétoriqueurs: A title given to the early school of French poetry of the fourteenth century, which, under the institution of the 'Puys' or literary societies, replaced lyrical inspiration by formal ingenuity, and made poetry a species of rhetoric.

Rhinthonic Comedy $=$ Hilarotragedy (q.v.).

Rhodianism: The term applied to the style in oratory arrived at by a compromise between the contending influences of Atticism (q.v.) and Asianism (q.v.). It takes its name from the school at Rhodes in which Apollonius and Molon taught, the canons of which were closer to those of the Atticists than those of Asianism. Cicero was trained in this school, and indeed Rhodianism is the keynote of the best Roman oratory. "The style to which Cicero was trained was that of Isocrates, purified by a study of the Attic orators from the extravagances which had corrupted it. Some writers held that this was far too florid and declamatory, and that Cicero's style would have been much purer in style if he had copied more closely the earlier Atticists'. But every language has its own particular limitations, and Cicero, while admiring the purest Attic models, was probably aware that their simplicity would less satisfy the ear in a language less naturally graceful and harmonious.

Rhodomontade: A speech or passage of boastful bluster. The word is derived from Rodomont, a bragging character in Ariosto's Oriando Furioso. By some that name is said to be connected with Rhadamanthys. Ariosto probably borrowed it from Bocardo's Rodamonte.

Rhopalic Verse (Greek $\mathfrak{\rho} \pi a \lambda o \nu$, a club): Verse composed of lines each word of which is longer 
than the preceding; so called on the analogy of a club, which grows thicker towards its end:as, for example, 'Si sedes liceat contingere cælicolarum'.

Rhyme: The identity in two or more words of the final vowel-sound and the articulations following it in each. In English prosody this constitutes a valid rhyme, anything short of it (viz. where the follow. ing articulations are not identical, when it is as. sonance, q.v.) not being admissible. In French prosody, however, this merely constitutes Rime Suffisante (q.v.), it being desirable that the rhyme should be ricke, i.e. that the rhymed syllables should have the consonant preceding the vowel. sound identical as well (see Rime Riche). Rhyme seems to have had its origin in the monkish leonine bexameters (see Leonine Verse). For varieties of Rhyme, Masculine, Feminine, Enclosed, Sdruccioli, Ocular, Rime Annexée, etc. etc., see s. $v$.

Rhyme Royal: A seven-line stanza introduced by Chaucer into English versification. The lines are usually decasyllabic and thymed on three rhymes after the formula ababbcc. Its name is supposed to be derived from the fact that it was used by James $\mathrm{i}$ in his Kinges Quair. It is the metre of Chaucer's Clerk's Tale and Troiius and Cresseide, Spenser's Ruins of Time and Hymn of Heavenly Love, and of Shakespeare's Lucrece.

Rhythm : Rhythm in poetry consists of the regular grouping or periodic recurrence of spoken sounds differentiated in certain ways. In quantitative verse the rhythm is of the nature of music, and consists of the grouping of syllables which in the time taken by their pronunciation bear a certain ratio to one another. In accentual verse rhythm consists of the grouping of syllables uttered with or without a certain stress. Inasmuch as in quantita. tive language all syllables bear certain ratios of time to each other, all quantitative prose has some rhythm; and as accentual language cannot by its 
nature be either all stressed or unstressed, it follows that in accentual prose also there must be some rhythm. By rhythm, however, we generally mean the more pronounced and balanced rhythm of verse, arranged and recurring according to a preconceived scheme.

Riding Rhyme: A term applied to the ordinary heroic couplet, i.e. the metre in which the Canter. bury Tales are written, on account of their being narrated by the several characters as they rode along.

Ridings : A term that used to be applied to the city pageants. See Pageant.

Rime Annexée: Verse in which every line begins with a word having the same initial syllable or syllables as the last word in the preceding line, e.g.-

'Ainsi se fait rithme annexée Annexant vers à autre vers, Versifiée et composée

Composant tels mots ou divers', etc.

(L'infortuné).

Rime Batelée: Verse in which the last syllable of each odd line rhymes to the fourth syllable of each even line. It was one of the metrical inventions of the latter end of the fifteenth century of Fiench poetry. The following example is by Marot :-

'Quand Neptunus, puissant dieu de la mer

Cessa d'armer caraques et galées,

Les Galliciens bien le durent amer

Et reclamer ses grands ondes salées'.

Rime Brisée: Verse with two rhymes in each line, an inner rhyme at the end of the cæsura and an end rhyme, rhyming to inner rhyme and end rhyme respectively. The following example is by Mellin de Saint-Gellais :-

' De cœur parfait, chassez toute douleur Soyez soigneux; n'usez de nulle feinte 
Sans vilain fait entretenez douceur ; Vaillant et preux, abondonnez la feinte'.

Rime Concatenée: Verse in which the last line of each stanza is repeated as the first line of the follow. ing stanza.

Rime Couée or Rithmus Caudatus: The ordinary romance stanza or 'romance six', as Professor Saintsbury terms it; a stanza of six eight-and sixsyllabled lines, 8.8.6.8.8.6, rhymed after the formula aabaab. It was a favourite metre with the early English ballads.

Rime Couronnée: Verse each line of which ends with a syllable repeated, as in the following lines:-

' Guerre a fait maint chatelet let

Et maincte bonne ville ville,

Et gaste mainct gardinet net'.

There is a variety of this in which the repetition is not of the identical syllable but of a rhyme, as

'Souvent je vais priant, criant'.

Both arose towards the latter end of the fifteenth century of French poetry.

Rime Empérière: A variety of rimes couronnies (q.v.) in which each line ends with a syllable repeated three times, as in the following lines by Massieu:-

'Benins lecteurs, très diligens, gens, gens, Prenez en gré mes imparfaits, faits, faits'.

Rime en Echo: Verse in which each line throughout ends with the same syllable or syllables.

Rime Equivoquée : Punning rhymes, as follows :-

' $\mathrm{Cy}$ gist, repose et dort léans

Le feu Evesque d'Orlíans'.

(Clement Marot).

Rime Fratrisée or Enchainée: Verse in which the rhymed syllable of a line is repeated at the begin. ning of the next line. The following example is by Marot :- 


\section{3}

'Dieu gard' ma maitresse et Régente, Gente de corps et de facon Son cœur tient, le mien en sa tente Tant et plus, d'un ardent frisson'.

Rime Insuffisante: A term applied in French prosody to rhymes which do not fulnil the require. ments of rime suffisante (q.v.).

Rime Kyrielle: A term of French prosody denoting verse in which the same line is repeated in refrain fashion at regular intervals, generally at the end ot each quatrain.

Rime Léonine: Verse in which the last two or three syllables of the rhymed lines are identical, e.g. :

\section{' Je vous pry rendre a present \\ Le cœur dont je vous fais present'.}

It is not to be confused with zers léonin or leonine verse (q.v.).

Rime Normande: A term of French prosody to denote the pronunciation of the infinitive ending '-er' to rhyme to 'amer', a pronunciation which it actually had in the seventeenth century. It de. rives its name from the fact that it is a dialectica? peculiarity of Normandy.

Rime Pauvre: A term in French prosody used to denote the converse of rime riche (q.v.).

Rime Rétrograde: Verses each line of which can be read backwards, word by word, without the loss of either sense or rhyme.

Rime Riche: The term in French prosody applied to a rhyme not only the vowel-sounds of which are identical, but also the consonne d'appuz or preced. ing consonant; a development of the twelfth century.

Rime Suffisante: The term applied in French pro. sody to the rhyme regarded as 'sufficient ' for literary purposes before the development of rime riche (q.v.). All that was then req'ired of a rhyme to be 
admissible was that the last sounded vowels and all articulations following them should be identica!.

Rimes Croisées: Verse in which the lines rhyme, not in pairs, but alternately after the formula ababcdcd.

Rimes Embrassées: Enclosed rhymes or verse rhymed after the formula abbacddc.

Rimes Mêlées: Verse rhymed after more than one scheme.

Rimes Plates, otherwise called Rimes Suivies: The term applied in French prosody to the arrangement of the rhymes in pairs after the formula aabbcc. Pairs of masculine rhymes generally alternate with pairs of feminine rhymes.

Rimes Redoublees: Verse in which a rhyme is repeated at least three times.

Rimes Tiercées: Sce Terza-Rima.

Ruigleader, The: The alternative name given by Puttenham in the Art of English Poesy to the figure of Prozeugma (q v.).

Ripresa: See Canzone.

Rising Rhythm: An accentual rhythm is said to be 'rising " when it commences with an arsis or unaccented syllable and closes with a thesis or accented syllable, as the accentual iambus or anapæst. The converse kind of rhythm is said to be 'falling'.

Rispetto: A species of Italian love-poem, generally in ottazia rima or other stanza forms, and usually extemporaneous.

Rithmus Caudatus : Sce Rime Couée.

Rococo: Originally an architectural term applied to a debased style of ornament which succeeded the first revival of Italian architecture. Applied to literary style it denotes meretricious extravagance.

Roman d'Aventures: The French term for the romance or novel of adventure and heroic prowess 


\section{5}

Roman de Renard: A cycle of beast-epics originating and developing in Picardy, Normandy, and Ile de France, which appeared in the middle of the twelfth century and continued to receive accretions for two centuries. It is an epic of beasts, but the spirit is bourgeois. Renard the fox is the hero throughout by virtue of his cunning, and comes of best in his encounters with all other animals, Noble, the lion; Chanticleer, the cock; Isengrin, the wolf; Bruno, the bear; Tibert, the cat, etc. The animals are beast types, but an element of humanity was imported into their depiction, and they became vehicles for satire and later for the complaints of the lower classes under oppression. The cycle includes the Latin Isengrinus of Nivard of Ghent (c. II5o), the German Reinhard Fl:chs, Reineke Fuchs (modernized by Goethe), Le Couronnement Renard (soon after 1250), Renard le Nouveau, by Gelée, and the last of them, Renard le Contrefait, written at Troyes before 1328 .

Romance: A class of prose narrative fiction which originated from the French chansons de geste and became very popular throughout Europe. The original type was always concerned with chivalrous prowess and amours. The most famous specimen or rather collection, dealing with the exploits and adventures of Amadis of Gaul, was redacted in French by Herberay in 1540 from a Spanish version. Others are Amadis of Greece and the Palmerin romances. Through the pastoral variety originated in Montemayor's Diana, it gave rise to the English romances of the early seventeenth century. Sec Novel.

Romancero: A romancero general, to give it the full name, is a collection of the Spanish verse 'romances' or early ballads. Of such collections there were several.

Romantic : See Classical.

Romantic Revival: The term usualls applied to the 
reaction in favour of romanticism from the Augustan ideals of 'classical ' correctness, the age of prose and didactic materialism. It has frequently been said that the French Revolution was the prime factor in this change: but while the French Revolution was accompanied in France by the romantic poetry of Chenier, and followed by such authors as Dumas and Victor Hugo: though, moreover, in Germany it stimulated the poetry of Goethe and Schiller and the prose of Novalis, Tieck, and Schlegel; in England the change had already begun. The blank verse of Thomson and his close study and accurate painting of nature, the work of Young, Collins, and Gray, showed the new trend of feelinz in favour of romanticism. This was undoubtedly nourished by the putilication of Percy's Reliques, which turned attention to the treasures of romantic folk-song and their primitive art. When the French Revolution came, therefore, it stimulated though it did not originate the romanticism of Scott, Coleridge, Wordsworth, Byron, Shelley, and Keats.

Rondeau : A poem of fixed form consisting of a tercet between twu quintains, rhymed upon two rhymes after the fornula aabba ab aabba. The tercet and second quintain are both followed by the rentre. nent, a repetition of the first few words of the rondeau extra metrum and without regard to rhyme.

Rondeau Redoublé: A fixed form of French poetry consisting of six quatrains, rhymed on two rhymes only after the formula abab, and alternately begin. ning with a masculine and a feminine rhyme. The four lines of the first quatrain are repeated in the last lines respectively of the second, third, fourth, and fifth stanzas, while the first words of the first stanza are added to the sixth extra metrum, and must not rhyme with any line in that stanza.

Rondel: A fixed f $\mathrm{rm}$ in French poetry consisting of two quatrains followed by a quintain rhymed after the formula abba abab abbaa. The last two lines 
of the second quatrain are the first two of the fitst, and the last line of the quintain is the first of the first quatrain.

Rouncifals: See Tumbling Verse.

Rubric: The directions and orders contained in the Liturgies of the Roman Catholic or Anglican Church because originally printed in red ink.

Runes: The letters of the Futhorc or alphabet of the Gothic tribes, usually carved on wood and filled in with paint. It is a moot point whether they borrowed them from the Greek colonists of the Black Sea or from the Roman alphabet.

Saber, El Gai : El gai saber (the gay science) was the Provençal name for the art of the troubadours, the flower of literature of the langue d'oc. This first appeared in the eleventh century, received its highest development in the $t w e l f t h$, and fell off after the Albigensian Crusade at the commencement of the thirteenth, when the great nobles, at whose courts and households the troubadours flourished, were too impoverished to maintain their former state. The gay science comprised certain set forms of lyric poetry, the Partimen (the French Jeu parti, q.v.), the Pastorela (French Pastourelle, q.v.), the Planh (q.v.), the Tenson (q.v.), the Alba (French Aube or Aubade, q.v.), the Estampie (q.v.), etc. etc. Among the more prominent troubadours may be named Bernart of Ventadour, Arcamon, Marcabrun, Peire d'Alvernha, Arnaut Daniel (the inventor of the sestina), Arnaut de Marsill, Bertran de Born, Peire Vidal, Guiraut de Borneil (the poet of the trobar clus or involved style), Gaucelm Faudit, and Folquet.

Sacre Rappresentazioni: A kind of pageant procession in Italy of a religious or liturgical nature performed at the Feast of Epiphany in the sixteenth century. 


\section{8}

Sæculum Rationalisticum: Another term for the Augustan period of English literature (lit. 'age of reason '). Sce Age of Prose and Reason.

Saga: The sagas are Teutonic or Scandinavian epics embodying the early historical traditions of Northern Europe. 'Among the mythical sages the most important are the Voluspa, Hervarar, Volsunga, and Vilkina, together with the saga of Ragnar Lodbrog'. Many of them are collected in the Himskringia of Snorro Sturleson.

Sapphic Verse : A stanza-form or strophe of classical lyric poetry, so named after the poetess Sappho (óto B.c.), ty whom, among other metres, it was used. As adapted by Horace to Latin poetry it consisted of three lines - $---\cup \backsim-\smile-こ$, followed by an Adonic, - $\smile-\sqsupset$. As Prof. Jebb pointed out, however, in his adaptation Horace modified the original rhythm of the Greek metre, which he only retains in a few lines, such as 'Laurea donandus Apollinari'.

Satanic School: The title given to Byron and his followers by. Southey in the preface to his Visions of Judgnicht. 'Immoral writers-men of diseased hearts and depraved imagination, who, forming a system of opinions to suit their own unhappy course of conduct, have rebelled against the holiest ordin. ances of human society . . the school which they have set up may be properly called the Satanic School, for though their productions breathe the spirit of Eelial in their lascivious parts and the spirit of Moloch in their loathsome images of atrocities and horrors, which they delight to represent, they are more particularly characterised by a satanic spirit of pride and audacious impiety which still betrays the wretched feeling of hopelessness wherewith it is allied. Primarily this article was levelled at Byron, but there have been included in the school so christened Rousseau, Shelley, Moore, Bulwer, Victor Huga, George Sand, and Paul de Kock. 
Satire : Satire is of Latin origin. The earliest use of the word satura was to denote a rude dramatic entertainment with no regular plot accompanied by music and dancing. It was used by Ennius, however, to denote a collection of poems in different metres on topics of general interest. These saturce or 'miscellanies' of Ennius sometimes preserved traces of the earlier dramatic form in their use of dialogue, and sometimes were couched in a tone akin to what is understood by the modern sense of satire. 'Miscellany', be it noted, corresponds most closely with the original sense of the word satura, which means a medley or hodgepodge, possibly with reference to the lanx satura, or dish of various fruits offered at rustic festivals on the altars of the country gods. These miscellaniez, which would more naturally have been written in prose had prose at this period been an instrument of literature, were succeeded by the saturce of Lucilius (born 168 B.C., the year after Ennius' death), in whose hands they acquired the character of satire in the acceptec. sense. These were followed by the satires of Horace (3j B.c.), which were not all definitely on the Lucilian model ; some were framed more after the earlier type, and are sketches of life, humorous narratives, or one-man discussions of social subjects. It was, moreover, impossible for Horace to use the same liberty of criticism that was permitted to Lucilius by reason of his social position. With the satires of Juvenal, however, which appeared in the reigns of Nerva, Trajan, and Hadrian, satire finally acquired its modern sense of a criticism and denur. ciation of social vices and abuses. The keynote of his fiery works is invective and scathing irony. Quintilian was therefore right in his dictum 'Satire is all our own' ('Satura tota nostra est').

Saturnian Verse: An indigenous Latin metre, of great ruggedness, which was employed in the earliest period of Latin literature. It was not quantitative, but accentual, unlike the metres borrowed subse- 


\section{0}

quently from the Greeks, and resembled fairly closely in rhythm Macaulay's instance 'The queen was in her parlour, eating bread and honey'. It was used by Livius Andronicus in his Latin translation of the Ody'ssey, and by Navius in his versified chronicle of the Punic War, scraps of which remain. The latter's epitaph has survived written in the same metre. The line 'Dabunt malum Metelli Næevio poeta', threatening the poet with vengeance for his attacks upon the noble Roman family of Metelli, will furnish a good example of this metre.

Satyric Drama : At the dramatic competitions at the Athenian festivals it was the practice for the last of each group of four plays which the competitors in tragedy had to exhibit to be what was known as a 'Satyric Drama'. I he exact nature of this play is not clear, no specimen having come down to us, but it was obviously intended to relieve the nervous tension which would be naturally created by the continuous spectacle of three tragedies by infusing a humorous element. It was apparently the custom for a satyric drama to deal with the subject of the foregoing plays, and to introduce some of the characters, but in circumstances lower in key than the high-pitched note of tragedy. The subject was generally dealt with humorously with a fantastic background of satyrs, whence the name was de. rived; but the play was never merely comic, such an abrupt transition from tragedy being too in. congruous and forced. It was rather poetical and romantic, with a whimsical vein of humour. The Alcestis of Euripides is supposed to have been an experiment in substitution for the usual satyric drama; it is a short tragedy with a tinge of comedy about it, which presumably served the same purpose as the regular thing. In later times the strict con. nection of the satyric drama with the trilogy or tetralogy ceased, and in 341 and 340 B.c. the proceedings at the City Dionysia commenced witb a 
single play of this description, which proves that its original function had been lost sight of. See Trilogy.

\section{Saynetes: See Entremeses.}

Scald : An ancient Scandinavian poet; one who composed poems in honour of distinguished men and their prowess, and recited or sang them on public occasions. The Norse scalds correspond roughly in function to the bards of the Celts and Britons.

Scansion: The arrangement and disposition of metres, quantitative or accentual.

Scatology : Obscene literature.

Scazon: This term, which means 'limping', denotes the variety of two metres, the iambic trimeter acata. lectic and the trochaic tetrameter catalectic, resulting from the inversion of the last foot, which produces a lame or halting effect, as (iambic) $\simeq-\cup-\underline{-}$ $\cup-\cup--\cup$; (trochaic) $-\cup-\longleftarrow-\cup-\cup-\cup-\cup--$. It occurs only in satiric poetry, and is alternatively called Choliambic or Hipponactean.

Scene: A subdivision of an act (q.v.) of a play. usually representing what passes between the same persons in the same place.

Scholasticism: The Aristotelian teaching of the mediæval schools and universities, characterized by acknowledgment of the authority of the Church, by being largely based upon the writings of the Fathers, Aristotle, and his Arabian commentators, and by its stiff and formal method of discussion. It may be said to have commenced about I000 A.D. Its first era is roughly divisible into two periods, the first of which, in the eleventh century, centred round the famous controversy of nominalism and realism, the issues being clear, and the partisans clearly opposed on simple and extreme grounds; while in the second period, which occupied the twelfth century, the opinions of both sides had become so differentiated that they ceased to be readily classed under one 
head or the other. Among the prominent men of the latter period may be mentioned Abelard (ro79II42), Gilbert of Poitiers (d. Ir54), and Peter Lombard (d. I I 64). The second era of Scholasticism falls roughly into three periods, in the first of which the general framework of the scholastic philosophy was constructed. The second period constituted the prime and heyday of Scholasticism, when, numbering among its professors such men as Duns Scotus, 'Durus' Durandus (d. r 332), Occam (d. r349), and Buridanus (d. after $135^{\circ}$ ), it reached its highest reputation and exerted its greatest influence. The third and last period came to a close with its practical extinction.

Scholiast: The term applied to the nameless early grammarians by whom Latin and Greek classical authors were annotated and commented upon. These annotations are termed 'scholia'.

School of Provence: A subdivision in a scheme conceived by Pope for a projected history of English poetry which he never actually carried out. The scheme, roughly scribbled on a sheet of paper, is preserved in Ruffhead's Life. After Pope's death it came to the knowledge of Gray, who was much struck by it, and contemplated a work on the same lines in collaboration with Mason, from which, how. ever, he was deterred by the knowledge that $W$ arton was attempting the same plan. The scheme consisted of two eras. Era i comprised: School of Provence, including Chaucer's Visions, Romaunt of the Rose, Piers Plowman, tales from Boccace, and Gower; School of Chaucer, including Lydgate, Occleve, Walter de Mapes, and Skekton ; School of Petrarch, including Surrey, Wyatt, Sidney, and Gascoigne; School of Dante, including Buckhurst's Induction and Gorboduc, and the origins of tragedy on the model of Seneca. Era ii comprised: School of Spenser, including Erown's pastorals, Fletcher's Purple Island, Alabaster, etc., Daniel, Raleigh, Milton's 


\section{3}

juvenilia, Heath, Habington, Golding, Fairfax, and Harrington; and School of Donne, including Cowley, Davenant, Drayton, Overbury, Randolph, Davis, Sir John Beaumont, Cartwright, Cleveland, Crashaw, Corbet, and Falkland.

Schoolmen: Professors or students of mediæval uni. versities; scholastics. See Scholasticism.

Science, The Gay. See Saber, El Gai.

Scolion: The term in Greek poetry for a drinking. song or a song to be sung at banquets. They were written by Pindar, and said to have been invented by Terpander of Lesbos (first half of seventh century B.C.).

Scôp (lit. 'shaper'): The poet or bard of the early Teutonic sagas.

Sdruccioli, Versi: Verses or lines with two short syllables after the last accented syllable (Italian prosody): hence lines with antepenultimate rhymes, in which the rhyming syllable is the antepenult: 'beautiful ', 'dutiful'.

Seicento: Lit. 'six hundred' (Italian), and by ab. breviation 'the sixteen hundreds', i.e. the seven. teenth century of Italian art and letters, which together with the latter half of the sixteenth century was a period of degeneracy compared with the brilliant period of the Cinquecento (q.v.). In literature the prevalent style was bombastic, inflated, and full of concetti or extravagant far-fetched metaphors and allusions, its chief prophet being Marini, from whose name this style has been termed Marinism (q.v.). Art was similarly affected, the fashionable style being what is termed rococo. The bad taste and decadent style of the period is termed seicen. tista; its notables seicentisti.

Senarius: A term of classical prosody denoting a line of six feet.

Sentimental Comedy: A species of dramatic com. position which made its appearance in England for 
a short period, and of which the most successful examples were Cumberland's II est Indian and Kelly's False Delicacy It took its origin, of course, from the comedie larmoyante (q.v.), and professed to deal with the virtues and distresses of private life rather than the usual subjects of the drama.

Septenarius Versus or Quadratus Versus: A metre used by the Greek and Roman comic writers consist.

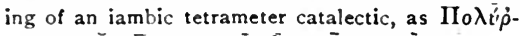

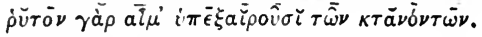

Sequentiæ: See Prosæ.

Sermon Joyeux: A species of dramatic monologue interposed between the performance of the sottie (q.v.) and a morality-play in France. It was a verse parody of sermons of the time, with text and the usual scholastic divisions, but of course with extreme licence of language. One piece which survives, the Franc-Archer de Bagnolet, bas been attributed to Villon.

Serpentine Verses: Lines of verse that begin and end with the same word, as "Ambo florentes ata. tibus, Arcades ambo'.

Serventois: A section of Provençal literature consisting of historical poems, including also, however, songs of the crusades, and moral, religious, and satirical pieces, the latter often directed against women.

Service Metre: Quatrains of alternate eight- and six-syllable lines with alternate rhymes, the metre of John Gilpin; so called, apparently, because it was the metre of the versified psalter sung in church. Milton's translations of some of the psalms are in Service metre. The first and third lines are usually unrbymed.

Sesquipedalian: Lit. 'one and a half feet long'; originally of words which occupy one and a half 
metrical feet, i.e. of about four or five syllables, hence a style or diction composed of such words, and consequently rather turgid and bombastic.

Sestet: A set or series of six lines with a rhyme scheme complete in itself.

Sestina (otherwise called Sixtine) is a poetical fixed form of considerable complexity, Provençal in origin. It consists of alexandrines arranged in three sixline stanzas followed by a three-line half-stanza, rhymed on two rhymes only, the final word of each line of the first stanza recurring throughout the rest of the poem in a certain order. The first stanza is rhymed after the formula abaabb, or to distinguish the actual words we may call it $a b^{2} a^{3} b^{2} b^{3}$. Tak. ing, then, for the final words of the second stanza the final words of the preceding stanza from last and first alternately, we get $\mathrm{b}^{3} \mathrm{ab}^{2} \mathrm{ba}^{3} \mathrm{a}^{2}$. Following the same rule for the final words of the third stanza, we get $a^{2} b^{3} a^{3} a b b^{2}$. All six end-words must appear in the closing half-stanza, those of the second, fourth, and sixth lines of the first stanza ( $\mathrm{ba}^{3} \mathrm{~b}^{3}$ ) coming at the ends of the three lines. The first, third, and fifth of the first stanza $\left(a a^{2} b^{2}\right)$ must appear in the body of the three lines respectively, but never at the cæsura. This is its finished form, but the more rudimentary earlier form was simpler. It is said to have been invented by Arnaut Daniel, the famous Provençal troubadour of the thirteenth century. Sestinas have been written in Italy by Dante and Petrarch, and Spain and Portugal by Cervantes and Camoens ; in France by Marot, St. Gelais, Ronsard, and du Bellay; and in England by Barnes and Drummond of Hawthornden. Swinburne has writ. ten a double sestina (Poems and Ballads).

Silence, The Figure of: An alternative title bestowed by Puttenham in his Art of English Poesy upon the figure of Apcsiopesis (q.v.). Another name used by him is 'the figure of interruption'. Silver Age of Latin Literature : The term applied 


\section{6}

to the period of decline in Roman letters which followed the Augustan Age and extended roughly from the death of Augustus in 14 A.D. to I50 A.D. It should, however, be 'divided into at least two stages, with widely different styles. The reign of Nero (54-68 A.D.) is the most flourishing period of what is called the Spanish School. This is marked by much brilliancy, but by overstrained and often contorted emphasis. Rhetoric both in prose and verse assumes undue prominence. In the philosopher Seneca, in his nephew Lucan, and in the young satirist Persius alike this feature is con. spicuous. The reigns of the Flavian emperors (6996 A.D.) show a reaction against this in comparatively dull but sober and learned writers like the elder Pliny and Quintilian, and laboriously correct verse. writers like Valerius and Silius. Under the last of these emperors, Domitian, it was only the brilliant but profligate wit of Martial, and the epigrammatic finish of Statius, which could find utterance in the gloomy tyranny stifling all higher literature'. With the reigns of Nerva, Trajan, and Hadrian free. speaking once more became possible, and the result was Juvenal, Tacitus, and the younger Pliny. See also Iron Age and Golden Age.

Silver-Fork School: The comprehensive term given to the class of novelists whose works are concerned with drawing-room etiquette and the external graces of good society. In particular it has been applied to Theodore Hook, Lady Blessington, Mrs. Trollope, and Bulwer Lytton.

Simile: A similitude expressed with explicit signs of comparison, differing in this from metaphor (q.v.), which is expressed without such signs. Thus 'the tongue of the just is as choice silver' is a simile; 'the tide of war' is a metaphor.

Single Supply, The: The alternative term applied by Puttenharn in the Art of Pocsy to the figure of Zeugma (q.v.) 


\section{7}

Sinking $=$ Bathos (q.v.).

Sixain: The term in French prosody for a six-lined stanza, often used by itself as a poem of fixed form; in which case it is generally rhymed either after the formula aabcbc, or that of aabccb.

Skeltonical: A term applied to a particular kind of poetry written by John Skelton (c. 1450-1529), consisting of a series of very short lines, with a swift, almost breathless rhythm, and frequent 'breaks' of repeated rhymes, as in his lines to Mistress Margaret Hussey. This 'ragged, tattered, and jagged' metre, as it has been called, is often charming, and it had probably considerable influence in breaking up the old long-line metres, such as the lumbering 'Poulter's Measure', in favour of more fluent and musical forms.

\section{Skolion: See Scolion.}

Smectymnuus: The nom de gzuerre assumed by a syndicate of Puritan divines, who produced a series of controversial pamphlets against episcopacy in reply to Bishop Hall towards the end of the first half of the seventeenth century. The name was constructed from the initials of the five authorsStephen Mlarshall, Edmund Calamy, Thomas Young, Matthew Newcomen, and William Spurstow.

Sock : See Buskin.

Socratic Irony : See below.

Socratic Method: The method which, according to the Platonic dialogues, was adopted by Socrates in his investigations of truth in any sphere of know. ledge. Socrates refers to it as $\mu a \iota \epsilon \nu \tau i \kappa \eta$, i.e. mid. wifery, because his part was to assist his interlocutpr to come to a knowledge of the truth, which he really possessed without being able to bring it forth him. self. The method was as follows: he would ap. proach some person of ordinary beliefs and opinions, and ask him a question in all apparent humility as though for information. His interlocutor promptly 
replied with the expected answer embodying the superficial views of the ordinary man upon the sub. ject. Thereupon Socrates, by a series of pertinent and searching questions, would compel the man to look past the surface into the true bearing of the matter, with the object of convincing him that his prejudices were incorrect by force of finding the whole body of his opinions confused and contradictory. The ground having thus been cleared and an open mind produced in his hearer, Socrates would proceed in the same fashion to construct a true theory. This attitude of socrates in approaching his interlocutor ostensibly for information, but in reality with the object of subverting his opinions and bringing him to a sense of his ignorance has been termed Socratic Irony, but it muit be remembered that the word connotes no sense of superiority or ridicule, but merely the original Greek sense implying that things 'are not what they seem', dissembling.

Solecism : Strictly, the faulty construction or arrangement of sentences, Barbarism (q.v.) being the faulty use of word, hence generally an offence against manners or good breeding. The word is said to have originally meant the corruption of pure Attic Greek spoken by the colonists of Soli in Cilicia.

Soliloquy: A speech delivered by a character represented alone upon the stage, purporting to be thoughts or meditations spoken aloud as though alone.

Sonnet: A poem of fixed form consisting of a stanza of fourteen lines rhymed in various manners. It possibly had its earliest origin in the fourteen-line rhymed 'Ghazel' popular at the Moslem court in Sicily, which might easily have found its way to the neighbouring mainland of Italy. In the hands of Petrarch, however $(1304-74)$, the sonnet first became a great literary form. He addressed about three hundred to Laura, generally identified with Laura de Noves. The Petrarchan form of sonnet consisted of fourteen lines broken up into an octave 
or series of eight lines and a sestet or series of six; both octave and sestet were rhymed upon two rhymes apiece, and with the beginning of the ses. tet the idea of the poem generally took a new turn. From Italy the sonnet spread to France, where they were written by Marot, Mellin de St. Gellais, etc.; and to England, whither it was introduced by Wyat on his return from his travels in Italy in 1527 , and Surrey. Both, however, departed from Petrarchan models: Wyatt preserved the octave, but broke up the sestet ; Surrey broke up both and evolved the scheme which has had most vogue, that of three quatrains and a final couplet. Subsequent writers adopted either of these arrangements: Sidney kept the octave, but broke up the sestet; Spenser altered the rhyme scheme by interweaving the rhymes of the second and third quatrain, but preserved the final couplet. Daniel, and Shakespeare after his example, reverted to the model of Surrey. Shakespeare allots two rbymes to each quatrain and the final couplet. Milton adhere, to the octave on two rhymes, but varies the sestet, allowing it either two or three rhymes and interweaving them in several ways. Sonnets are usually written in decasyllabic lines, but there are exceptions, such as Sidney's dodecasyllabic specimen, and one of shakespeare's in octo. syllables. The sonnets in Watson's Hecatompathia, though Italian in spirit, are not true sonnets, as they consist of eighteen-line stanzas of three sestets.

Soraismus: The term of rhetoric for the vice of in. terlarding diction with foreign expressions and words disguised in a cloak of the native tongue.

Sotadic Verse: This measure consists of four ionic

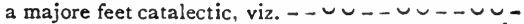
․ It was used by Sotades and other poets in ethical and satirical poetry, and was, according to Aristides Quintilianus, never suns, but always recited. Among the Romans it was used by Ennius: occasionally by Plautus, and by Martial. 
Sottie: A variety of farce which appeared in France in the fifteenth century. It had its origin either in a secularization of 1 he celebration of the Feast of Fools, or in the parade of fools which sometimes preceded a mystery The performers, arrayed in motley and long-eared caps, divided among them. selves the various provinces of human folly. Though originally a mere diversion, it could rise to satire or even political criticism. There was a guild in Paris of actors for the sotties, who called themselves Enfants sans Souci.

Spanish School of Latin Literature: See Silver Age.

Spasmodic School, The: A nickname applied to a group of authors chief among whom were Alexander Smith (1830-67) and Philip James Bailey (b. 1816), author of Festus. The term bas reference to ' $a$ certain unreality and difficult straining after effect' which characterized their productions. They were ridiculed by Prof. Aytoun in his Firmilian, a Spas. modic Tragedy.

Spenser, School of: See School of Spenser.

Spenserian Stanza: A stanza form invented by Edmund Spenser in adaptation of the Italian ottava rima (q.v) and used by him in his Faerie Queene. It consists of eight decasyllabic lines followed by an alexandrine, and rhymed upon three rbymes after the formula ababbcbcc. It was used by Thomson in his Castle of Indolence, and by Byron in Childe Harold, etc.

Spondee: The metrical foot consisting of two long syllables (- ) The word is derived from the Greek $\sigma \pi 0 \nu \delta \dot{\eta}$, a libation, on account of its slow and solemn measure, which made it suitable for ceremonial occasions.

Spondiacus Versus (or Versus Spondiazon): A hexameter with a spondee in the fifth foot, as 'Cara 
deum soboles, magnum Jovis incrementum': It is used to express grief and solemnity of occasion.

Stanza: When a poem is written in sets or series of lines, each set reproducing the exact metre, rhyme scheme, and arrangement of the others, such sets are called stanzas.

Stasimon: One of the long choral odes sung by the chorus in Greek drama to fill up the pauses between the action. Stasimon means the 'stationary' ode, so called, not because the chorus was stationary during their singing, but because they remained in the orchestra the whole time, in distinction from the Parodos and Exodos (q.v.), which were sung as the chorus was respectively entering or leaving the orchestra. They were, in fact, accompanied by dancing: during the strophe the chorus moved to the right, during the antistrophe to the left, and during the epode it remained in its original position. See Chorus.

Stichomythia: A passıge of disirgue in a Greek play consisting of single comp'e'ce lines spoken by each interlocutor in turn.

\section{Storm and Stress : See Sturm and Drang.}

Stornello (Tuscan tornare, to turn): A variety of poem commonly sung by the peasants of Tuscany in which certain words are, as it were, turned abou? barped upon, and repeated, as e.g.-

'I'll tell him the white and the green and the red

Mean our country has flung the vile yoke from her head:

I'll tell him the green and the red and the white

Would look well by his side as a sword-knot so bright :

I 11 tell him the red and the white and the green Is the prize that we play for-a prize we will win '.

Strophe : The stasima or main lyric odes delivered by the chorus in Greek tragedy between the episodes or acts were divided into two or three sections, 
named respectively the Strophe, Antistrophe, and Epode. The metrical arrangement of the antistrophe reproduced the metrical arrangement of the strophe, while the epode, which did not occur very frequently, was an additional passage following both strophe and antistrophe. These choral odes were generally sung, but little more is known concerning the circumstances of their delivery. Some have suggested that the strophe was delivered by one halfchorus, the antistrophe by the other, and the epode by the whole, but this theory has little support. It has also been stated that in their 'dancing' or rhythmical evolutions the chorus turned to the right during the strophe, to the left during the antistrophe, and remained stationary during the epode.

Sturm und Drang or Storm and Stress: The name given to the period of intellectual convulsion in German literature which occupied the last quarter of the eighteenth century, derived from the title of a drama by Klinger, named. Sturm und Drang. 'The wisdom and extravagance of the age united in one stream. The masterly criticism of Lessing, the enthusiasm for Shakespeare, the mania for Ossian and the northern mythology, the revival of ballad literature and parodies of Rousseau all worked in one rebellious current against established authority. There was one universal shout for 'nature'. With the young nature seemed a compound of volcanoes and moonlight. To be insurgent and sentimental, explosive and lachrymose, were the true signs of genius' (G. H. Lewes, Life of Goethe). The period is mainly represented on its explosive side by Goethe's Berlichingen and Schiller's Robbers, and on the sentimental side by the former's Sorrozes of Werter.

Style: In an absolute sense this word denotes an approved method of artistic expression. It may also mean, in a relative sense, the form of expression and diction of a literary composition, as e.g. a turensic or didactic-style, viz. the form of expression 
most suited to an oratorical or didactic composition. When we speak of the style of a particular author however, we refer to that form of expression which is the outcome of his peculiar character or individuality (in which sense the style is the man). It is not necessary that a style should be markedly peculiar or unusual to be individual; even if it is hard or impossible to trace the elements which constitute the difference, the individuality is none the less perceptible. Inasmuch as style is the external expression of the author's character, the imitation by others of an individual style can have little good effect, except as a general corrective of common faults, so far as the author imitated is free from them.

Substitute, The : The alternative title bestowed by Puttenham in his Art of English Poesy upon the figure of Hypozeuxis (q.v.).

Submutatio:: The Latin term for the figure of Hypallage (q.v.).

Sung Verse: The name given to the Old English ballad-metre 'The queen was in her parlour II eating bread and honey', and its Anglo-Saxon prototype, because meant to be sung, in contradistinction to 'rhetorical' verse. The half-line contained four stresses or accents, two of which were 'full stresses', i.e. those which received the main accent, while the other two were 'half-stresses', i.e. accented less markedly. These 'full' and 'half' stresses were grouped in a certain sort of balance.

Surnamer, The: The alternative name given by Puttenham in his Art of English Poesy to the figure of Antonomasia (q.v.).

Sword and Cloak Romances : See Cape et Epée, Roman de.

Syllepsis: The connection of a verb or adjective with a compound subject. See also Zeugma.

Symbolism : The tendency or characteristic of some 
writers to invest things with symbolic meaning, to regard them as signs or symbo's of qualities, passions, or affections.

Symbolistes: Symbolistes or Decadents is the rough general term applied to the imitators of Verlaine and Mallarme. Verlaine $(1844)$ had escaped from the Parnassiens (q.v.) into Bohemia, and rebelled against the strict laws and rules of poetical composition laid down by certain of that body. Him. self gifted with a marvellously musical ear, he paid especial attention in his compositions to two para. mount qualities, delicate and melodious cadence, and suggestiveness (a poor equivalent of the French nuance). He deliberately abandoned point, finish, eloquence, and rich diction in search of these two ideals. designing only to produce a mist of melodious language in which the idea fused and became one with it expression. This also was the aim of Mallarmé, who was steeped in the spirit of Poe. Such a tendency lent itself to symbolism, and com. positions of this school are occasionally within measurable distance of being unintelligible. Among other Symbolistes may be cited Henri de Regnier and Albert Samain. The worst type of this tendency, to which in common parlance the term 'decadent is affixed, amounts to little more than a callow and morbid mysticism.

Symploce : The rhetorical figure in which the initial and final words of a clause are repeated at the beginning and end of successive clauses: "Mercy descended from heaven to dwell on the earth; Mercy fled back to heaven and left the earth'. It is a combination of epanaphora and epistrophe (q.v.).

Symposium : A composition consisting of a succession of short paragraphs or articles written by several well-known men, and expressing their respective views upon a single topic propounded for considera. tion. 


\section{5}

Synæresis: The contraction of two syllables or vowels into one; more especially the contraction of two vowels so as to form a diphthong, as 'ne'er' for 'never', 'Atreides' for 'Atreïdes'. See Metaplasm.

Synalæpha: The contraction of two syllables into one, or the blending of two successive vowels by one or more of the processes termed Synæresis, Synizesis, Crasis, or Elision (q.v.). The term is particularly applied to the obscuring or suppression of a final vowel sound before an initial vowel sound, as 'th' end'; it should not strictly be applied to cases where the final vowel sound entirely vanishes, as in $\mathrm{lam} \mathrm{i}$, where there is no vestige of the final ' $e$ '.

Synathrœsmus : The term in rhetoric for a species of Auxesis (q.v.) consisting of the accumulation of words and phrases expressing different particulars or aspects of the same thing.

Syncope: See Metaplasm.

Synecdoche: The rhetorical figure of allusion to the part instead of the whole, as the use of "the wave in the sense of 'the sea', 'keel' for 'ship', 'a hand' or 'a head ' for 'a man', etc.

Synesis: A construction in accordance with meaning, and not with strict grammatical form, as 'Capita conjurationis virgis cæsi sunt'.

Synizesis: The combination into one syllable of two vowels that would not form a diphthong.

Synonym: A word having the same meaning as another word in the same language is said to be a synonym of it.

Systole: The grammatical ierm applied to the licence of shortening a long syllable, the converse of Diastole (q.v.). 
Table-talk : Collections of casual dissertations, conversations, or obiter dicta of distinguished men, as though let fall by them in the familiar intercourse of meals, e.g. Luther's or Selden's; Holmes's Auto. crat is a species of table-talk in the literal as well as the usual sense.

Tags: The rhymes alone of a piece of rhymed poetry ; hence to ' $t a g$ ' a piece of blank verse is to fit the lines with pairs of rhymes. See Bouts Rimés.

Tapeinosis: The literary vice of the use of mean or undignified expressions.

Tautology: The unnecessary repetition of a phrase or sentence in similar language or periphrasis. Ihus, according to De Quincey, the lines

\section{'Let Observation with extensive view Survey mankind from Chili to Peru'}

are tautologous, that couplet merely amounting to - Let Observation with extensive observation observe mankind extensively'. In the Art of English Poesy of Puttenhan, who also calls it the figure of Selfsaying, it denotes alliteration.

Telestic Verse : See Acrostic.

Telestich : See Acrostic.

iell-Cause, The: Puttenham's alternative English term for the figure of Etiologia (q.v.).

Tenson: A form of Provençal lyric poetry consisting of a debate between two interlocutors on some courtly subject of love or chivalry, each taking a stanza in turn. See Saber, El Gai.

Tercet: A series or set of three lines, either by itself or as forming part of a greater series.

Terpsichore: The Muse of choral poetry; often referred to in the specific sense of that class of literature.

Terza Rima (in French, Rimes Tiercées): A poetical fixed form consisting of lines (in French, alexan. 
drines) arranged in tercets with a final quatrain rhymed after the formula aba bcb cdc, etc., closing with the quatrain yzyz.

Terzetti: Lines written in terza rima (q.v.), as Milton's translation of Psalm ii.

Terzina: A stanza of three lines (Italian).

Tetralogy : See Trilogy.

Tetrameter: The term given in Greek prosody to a line consisting of four 'metres', as to the nature of which see Trimeter.

Tetrastich : A short poem or epigram of four lines.

Thalia: The Muse of gaiety, pastoral, and comedy; often referred to specifically in the sense of those classes of literature.

Thesis : See Arsis.

Threnos: A dirge; the title of the closing series of triplets to Shakespeare's The Phonix and the Turtle, in the Passionate Pilgrim.

Tmesis: The separation of the parts of a compound word; as 'septem- subjecta -trioni'; 'space to breathe, how short soever'.

\section{Togatæ: See Fabula Togata.}

Top-shelf Literature: A common bookseller's term for literary works dealing with delicate or indelicate subjects.

Topographia: Writing descriptive of scenery, architecture, or locality, whether real or imaginary. This is the meaning it bears in Puttenham. The word may, however, fairly be applied to a class of publication which has become popular of late, viz. the description of districts and localities, their natural features, history, legends, and antiquities.

Toscanaggiamento: The practice of turning literary compositions written in the various local dialects of Italy into Tuscany as the fashionable language. It 


\section{8}

had begn before the appearance of the Divina Commedia, which was written in Tuscan.

Touchstone Method of Criticism: A method adopted and counselled by Matthew Arnold in the Essays on Criticism (second series). He says: 'There can be no more useful help for discovering what poetry belongs to this class of the truly excellent, and can therefore do us more good, than to have always in one's mind lines and expressions of the great masters, and to apply them as a touchstone to other poetry'. The idea is not, as has been said, to compare authors by 'samples', but to test literature which we seek to appraise by means of lines or passages of obvious poetic value, in com. parison with which the poetry under consideration will ring false or true according to its merit.

Tragédie Bourgeoise : Sec Comédie Larmoyante. Tragédie Raisonnable: See Raisonnable, Tra. gédie.

Tragedy: Tragedy, like comedy, arose out of the earliest germ of the drama, the festivities at Athens in honour of Dionysus. After the sacrifice of a goat, from which the name itself is derived, tragedy meaning 'goat-song', a chorus of rustic singers gathered round the altar to sing a hymn in honour of the god, relating some of his legendary adventures. This chorus. as purporting to consist of the satyrs, actual attendants of Dionysus, would narrate in a vivid and personal fashion wbich carried the seeds of dramatic representation. In the next stage the leader of the chorus, or coryphaus, would enact the part either of the god or of a messenger, and relate some exploit, upon which the chorus would comment in their hymn (which received the name of 'dithyramb', a word of doubtful origin, but apparently akin to the Latin triumphus). Here was the fact of drama, that is of 'action' as opposed to narration, complete; but the next step, the innovation due to Thespis (B.C. 536), made 'action' 


\section{9}

possible in a more extended sense, by providing that the coryphrus should carry on a sort of dialogue between the pauses of the choral hymns with one member from the chorus, who was entitled the 'answerer' (ن் typed in Greek to denote an actor. With the invention of dialogue, tragedy, or ratber drama, was ripe for development. So far comedy had a similar origin; but, as the name comedy (villagesong) implies, more attention was paid to this species from the point of view of country revels, and the rude jests of a village carnival, ribaldry and coarseness, the old licentious merriment of the satyrs being a traditional feature of the worship of Dionysus. Tragedy and comedy therefore developed on parallel lines, as offshoots of the cult, the first as dealing with legends of the god, and subsequently the legendary history of Greece, the second by paying special attention to the scurrilous coarseness preserved by the conservatism of the Greeks as an act of worship. Tragedy was soon recognized by the state and incorporated as a state institution in the national festivals in about the latter half of the sixth century. Comedy did not receive similar recognition until the first half of the fifth century. Phrynichus $(5 \times 2-476)$ wrote tragedies with only one actor; but with Eschylus, who introduced a second actor, the action became inde. pendent of the chorus, which thereafter assumed a subordinate position, and drama in the modern sense commenced. In comedy the first steps at development were taken by Dorians, who had a turn for 'broad drollery and homely satire', and who dramatized the dialogue of 'comic' chorus and actor into short farces. Susarion of Megara (580 B.C.) wrote what became known as Megarian farces. After him, however, there were no prominent writers of comedy until Chionides, who began to exhibit in 487 B.C., and Magnes. These were followed by Cratinus, Crates, and Eupolis, for whom 
and for the subsequent development of Greek zomedy sce Old Comedy. From the course of their respective developments it is natural that the term 'tragedy' should be applied to plays of a serious nature dealing with strong passions and violent catastrophes, and that plays dealing with humorous situations and absurdities should be called comedies. The rise of drama, both tragic and comic, after the Renaissance, however, had a different origin. See Drama.

Tragedy of Blood: See Blood, Tragedy of.

Tragi.Comedy: A dramatic piece partaking of the nature of both tragedy and comedy, i.e. with tragic situations which right themselves and end happily. Fletcher gives the following jesting definition in the preface to the Faithful Shepherdess: 'A tragi. comedy is not so called in respect of mirth and killing, but in respect it wants deaths, which is enough to make it no tragedy, yet brings some near it, which is enough to make it no comedy'. The class of play is also referred to by Sidney in his Apology for Poetry.

Tragic Irony: See Irony, Tragic.

Transport, The Figure of: The alternative title given by Puttenham in his Art of English Poesy to the figure of metaphor (q.v.).

Trespasser, The: The alternative title given by Puttenham in the Art of English Poesy to the figure of Hyperbaton (q.v.).

\section{Triad: See Triban.}

Triban: A variety of Welsh literature consisting of a series of triads or triplets, sets of three lines, usually containing observations and proverbial utterances upon matters of legend.

Tribrach: The metrical foot consisting of three short syllables (ひしし).

Trilogy : At the dramatic competitions which formed 


\section{1}

such an important part of the Athenian festivals $c$ the City Dionysia and Lenæa, it was the practice for each of the three competitors in tragedy selected to exhibit a group of four plays consisting of three tragedies and a satyric drama (q.v.). These plays were not necessarily connected in point of plot or subject, but they frequently dealt with the same legend and formed a series either of the whole four or of three tragedies. Where the three tragedies were unified by community of subject, the satyric drama dealing with some other story, the first three were termed a trilogy; and where the satyric drama was also included in the unified scheme, all four plays dealing with the same subject in a sort of cycle, they were called a tetralogy. An instance of the latter is the Orestean tetralogy of Eschylus, which consisted of the Agamemnon, Choephori, Eumenides, and Proteus. For an instance of the former we may turn to the Edipodeia of the same author, which consists of the Laius, Edipus, and Seven against Thebes; indeed, the custom of writing plays in trilogies and tetralogies is generally ascribed to Eschylus, who popularized the practice if he did not invent it. Upon his death, however, they fell out of favour, and Sophocles introduced the custom of making each play a separate work of arr. The term trilogy was apparently formed by analogy upon tetralogy, which means strictly a group of four speeches, and was probably originally applied to the groups of speeches in fictitious lawsuits-two for the prosecution and two for the defence-written by Greek orators as models for their pupils. Three of such tetralogies by the orator Antiphon have come down to us.

Trimeter: In Greek prosody the trochee, lambus, and anapæst are not reckoned separately in single feet, but in pairs of feet, called dipodes or metres. A trimeter, therefore, is a line consisting of three such metres, e.g. an iambic trimeter (the ordinary iambic verse) $レ ー レ-|\cup-レ-| \cup-\checkmark-$. 


\section{2}

Triolet: A poem of fixed form consisting of a huitain or eight-line stanza rhymed upon two rbymes after the formula abaabab. The fourth line must be a repetition of the first, and the seventb and eighth of the first two.

Trionfi: A class of poem written by Petrarch consisting of a sort of allegorical vision dealing with abstract qualities. The poet sings of the might of Love, Chastity, Death, Fame, Time, Eternity, etc., set forth in the description of the long procession of their captives or votaries. The poem is couched in the form of an imaginary pageant or procession (as the name, derived from the Latin trimphus, implies), in form an analogy to the 'Florentine trionfi or train of masked figures on foot and in chariots', which arose out of the liturgical proces. sion, and assisted in the development of the masque and pageant.

Triplet: A stanza of three lines on one rhyme, as in Tennyson's Three loices.

Tristubh : A Vedic metre (quantitative) consisting of a catalectic line of three quadrisyllabic feet, the first two composed of syllables of either quantity, the third being an amphibrach, as $\simeq \simeq \cup \cup \mid \cup \underline{\simeq} \underline{\cup}$ $\checkmark-\cup$.

Iritagonist: As Eschylus introduced the deuteragonist (q.v.) or second actor into Greek drama, so Sophocles introduced a third, who was called the tritagonist. In the apportionment of parts, several of which were taken by each, he took those which required least acting, for which a powerful voice alone was necessary. Hence what we should term "heavy" parts were usually allotted to him, such as the gloomy tyrant and sceptred monarch. Both he and the deuteragonist were entirely subordinate to the protagonist (q.v.) or leading player, by whom they were appointed.

Triumphal: According to Puttenham, a form of 


\section{3}

'poetical rejoicings', viz. the species celebrating victory or peace: "they were used by the ancients in like manner as we do our general processions or Litanies with banquets and bonfires and all manner of joys'.

Trobar Clus: The obscure style of Provençal poetry which revelled in difficult or ingenious rhymes and complicated devices. Its master was Arnaut Daniel, a celebrated Provençal poet who flourished about I $80-1200$. One of his patrons was Richard Cœur de Lion.

Trochaics: Any metre composed of trochees; more usually, however, the trochaic tetrameter catalectic.

Trochee: The metrical foot consisting of a long syllable followed by a short one $(-\cup)$. It is derived from the Greek $\tau \rho \circ \chi \hat{a} \iota 0 s$, running, because it is a tripping or running metre.

Troilus Verse: The name given by James $i$ in his Reulis and Cautelis, etc. (1585) to Rhyme Royal (q.v.), probably on account of its use in Chaucer's Troilus and Cresseide.

Trojans: In the early dawn of the study at Oxford of Greek letters and the humanities there appeared about I 518 a 'body of brutal obscurantists' who did their best to decry and discourage by every means in their power the study of Greek, calling themselves 'Trojans'. With the object of getting rid of this barbarous pest More wrote his Epistle to the University in 1519 , and in consequence of this and other complaints the king (Henry viii) interfered and the 'Trojans' were suppressed.

Trope: 'An expression altered from its natural and obvious sense' (Saintsbury).

Troubadour or Trobador: The term assumed by the poets of Provence who wandered from court to court, or became in some cases the guests and in. timates of kings. Sec Saber, El Gai. 


\section{4}

Tumbling Verse or Rouncifals: Terms employed by James $\mathrm{i}$ in his $R$ eulis anci Cautelis, etc. (1585) to denote doggerel alliterative lines.

Turkey-Carpet Style : A term arising from a pas. sage in Macaulay's critique of Robert Montgomery's poems. 'His writing bears the same relation to poetry which a Turkey carpet bears to a picture. There are colours in a Turkey carpet out of which a picture might be made. There are words in Mr. Montgomery s writing which when disposed in cer. tain orders and combinations have made, and will again make, good poetry. But as they now stand they seem to be put together on principle in such a manner as to give no image of anything "in the heavens above, or in the earth beneath, or in the waters under the earth" ".

Twins. The Figure of: The alternative title given by Puttenham in his Art of English Poesy to the figure of Hendiadys (q.v.).

Ultra Crepidarian Critics: The designation which Hazlitt says in his Essay on Criticism has been given to the class of 'verbal critics-mere word. catchers, fellows that pick out a word in a sentence and a sentence in a volume and tell you it is wrong. They degrade by reducing you to their own standard of merit; for the qualifications they deny you, or the faults they object, are so very insignif. cant that to prove yourself possessed of the one or free from the other is to make yourself doubly ridiculous'. The phrase is, of course, derived from the proverb: 'Ne sutor ultra crepidam' ('Let the cobbler stick to his last '); implying that such critics merely treat of the trifles of their own limited experience, beyond which they cannot go.

Unities, The: The so-called Three Unities, upon which countless false theories of dramatic art have been fourded. are themselves based upon miscon. 
ceptions of various passages in Aristotle's Poetics. Aristotle, with the soundness and wise comprehension of general principles which usually inspires bis utterances, does lay stress upon the importance of Unity of Action, meaning thereby an organic unity, the inward principle which reveals itself in the vutward whole; the connection of all the successive incidents 'by an inward and causal bondby the law of necessary and probable sequence'. Further than this, however, he does not go; but the following passage occurs in the Poetics: "Epic poetry and tragedy differ, again, in length: for tragedy endeavours, as far as possible, to confine itself to a single revolution of the sun, or but slightly to exceed this limit; whereas the epic action has no limits of time'. Upon this passage, which is merely a statement of the general usage of the Greek stage, bas been founded the Unity of Time, viz. that the period covered by a play should not exceed twenty-four (or, according to some views, twelve) hours. Remoter still, the Unity of Place, viz. that the action should take place in one locality, and the scene should not be shifted for one distant, is not even hinted at in Aristotle, but is merely inferred from the Unity of Time. The fact is, of course, that while the latter two, or minor, unities were generally, though not universally, observed by Greek drama, this was on account of the accidents of its special conditions, and in no way referable to the primary principles of dramatic art itself. The French critics who interpreted these passages, Corneille, D'Aubignac, Dacier, etc., elevated these pseudo-Aristotelian minor unities into paramount rules of art, subordinating the Unity of Action; whereas, as Aristotle preached, and every. great playwright, including Shakespeare, has practised, it the Unity of Action is observed, the others may be safely neglected.

Urania: The Muse of astronomy; often specifically referred to in the sense of that branch of science. 
Uranistes: See Jobelins.

Utopia : A work describing some ideal and imaginary polity embodying the writer's theories of ethics, politics, or economics, and serving as a concrete illustration of them. This class of literature draws its inspiration generally from Plato's Republic, through, perhaps, St. Augustine's De Civitate Dei, Sir Thomas More's Utopia, and Bacon's New Atlantis.

Vers Eumolpiques: The name given by Fabre d'Olivet to his experiments in French blank or rhymeless verse.

Vers Libéré : A kind of French verse invented by the Décadent school which approximates to the nature of cadenced prose. It has no cæsura, the lines are of any length, and rhyme is almost replaced by assonance and alliteration. The title is that bestowed on it by its inventors.

Vers Libres: A term applied in French prosody and generally to verse composed of lines of no uniform length.

Vers Mesurés: The name given to the experiments in rhymeless French verse scanned by quantity on the model of Greek and Latin metres which appeared at the end of the fifteenth century and later.

\section{Verso: See Recto.}

Vice, The: In the old moralities (q.v.) the character of Vice developed on comic lines, and became the fool or clown of the piece. As in French moralities, where his name was 'Badin', the character was always taken by the best actor of the cast. His traditional fooleries exercised a strong influence over the early English drama; some such clown, whose impromptus frequently played havoc with the 


\section{7}

actual play, was imperatively demanded by the audience. Shakespeare met the difficulty by introducing a comic part in many of his plays, which should satisfy the 'groundlings' without artistic loss to the piece. In common allusion a vice meant a clown or buffoon. Compare Hamlet, iii, 4 : 'a vice of kings'.

Villanelle: A poem of fixed form, consisting of a series of tercets concluded by a quatrain, rhymed on two rhymes only after the formula aba aba, etc., to abaa. The last line of each even tercet is the first line of the first tercet; the last line of each odd tercet is the last line of the first tercet; while the first and third lines of the first tercet are the third and fourth of the quatrain.

Virelai : The name is derived from the Old French vireli, a sort of refrain, under the influence of lai, to the form of which the virelai is analogous. The virelai ancien consists of lines of more than one length arranged in stanzas, each rhymed upon two rhymes. One of these predominates in each stanza, and the non-dominant rhyme of one stanza becomes the dominant rhyme of the next. The virelai nouveau is rhymed on two rhymes, one of which predominates throughout. The first two lines are repeated by way of refrain at intervals, either together or alternately. In one example the first line ends the first, third, and fifth stanza; the second line the second and fourth; while both together conclude the sixth and last. The lines may be seven-syllable, eight-syllable, ten-syllable, or alexandrine.

Volkslieder : Lit. 'folk-songs (German); i.e. ballads and songs of popular or national origin.

Wardour Street: Wardour Street has acquired 2 reputation for the sale of antiques and curios of doubtful authenticity. Hence the term is applied 


\section{8}

in literature to the use of archaic language and the representation of antique (particularly mediæval) accessories with the object of producing the neces. sary colour of antiquity in a work of fiction depicting past ages. The word may or may not contain an imputation of the spurious nature of such "pro. perties'.

Waverley Novels: A term collective!y applied to the whole body of Sir Walter Scott's novels, exclu. sive only of the tales entitled Aunt Margaret's Iirror, The Laird's Jock, and The Tapestried Chamber. The name is derived from the first of the series, Wazerley, published in 1814 . To this novel Scott did not prefix his name, fearing that it might compromise his poetical reputation.

Wertherism: The term often applied to a form of sentimentalism of a rather sickly and maudlin char. acter infused with settled melancholy and distaste for life. The name is, of course, derived from Goethe's Die Leiden Des Junger Werther (1774), in which the hero Werther pines with love for the wife of his friend until he puts an end to his life. Wertherism had a considerable vogue, and con. siderably influenced Byron's poems. The 'Byronic' gloom was, however, rather less maudlin and more defiant.

Wessex Novels: The name given by their author to the novels of Thomas Hardy as dealing in the main with scenes and characters in a tract of country termed by him Wessex, which comprises the westerly counties of England from and including Hampshire westwards, and as far north as Oxford, the placenames of wich are usually disguised. The novels exhibit a character of somewhat pessimistic realism, together with an exceptional insight into human psychology and much power and pathos.

Wit: Though in its modern sense wit is equivalent to cleverness, intelligence, or sparkling humour, it 
usually bore in the works and time of Dryden the meaning of the imaginative faculty (vide infra).

Wit-Writing: The term invented by Dryden in his prefatory 'Letter' to the Annus Mirabilis, in the course of which he lays down the following distinction: 'The composition of all poems is, or ought to be, of wit: and wit in the poet, or wit-writing (if you will give me leave to use a school-distinction), is no other than the faculty of imagination in the writer which, like a nimble spaniel, beats over and ranges through the field of memory, till it springs the quarry it hunted after; or, without metaphor, which searches over all the memory for the species of ideas of those things which it designs to represent. Wit-written is that which is well defined, the happy result of thought or product of imagination'.

Wit-Written : See above.

Yellow Journalism: Sensational and trashy journal. ism; so called from the colour of the binding of maga. zines and literature of that class in America, where it chiefly flourishes.

Zeugma: The connection of a verb or adjective with two words or clauses to which it does not equally belong, or in the juxtaposition of which there is some incongruity; a species of ellipse, as e.g. ' $\mathrm{He}$ took his hat and his leave'. In Puttenham the word means no more than the variety of ellipse consisting of the use of a single verb to govern two or more clauses. He distinguishes the following species of Zeugma, viz. Prozeugma, where the verb which is to do duty for all occurs in the first of several clauses; Mesozeugma, where the verb is placed in a central clause and does duty for those before as well as after; and Hypozeugma, where the verb is in the last clause and does duty for all the preceding. With Puttenham the variety of Zeugma 


\section{0}

in which the one verb or adjective does not equally belong to both clauses, or the connection of which is attended by incongruity of either form or sense, receives a separate name, and is termed Syllepsis as e.g.-

'My lady laughs for joy and I for woe', where the third person 'laughs' does duty also for the first person 'laugh'. 


\section{INDEX}

Abaser, the Abecedarian hymn Abecedarian psalms Abode, fig. of Abuse, fig. of Acatalectic Accent Acromonogram. maticum Acrostic Act Acyrology Adonic Age of Prose and Reason Agon Agony column Albino poets Alcaic verse Alcmanian metre Alexandrianism Alexandrine Allæostrophic Allegory Alliteration Alto estilo Amblysia Amœbean ode
Amoret

Amphiboly

Amphibologia

Amphibrach

Amphigouri

Amphimacer

Amplification

Ampulla

Ana

Anachronism

Anacoluthon

Anacreontics

Anacreontic verse

Anacrusis

Anadiplosis

Anagnorisis

Anagram

Anagraph

Analecta

Analogy

Anapæst

Anaphora

Anastrophe

Anceps

Annomination

Annus mirabilis

Antanaclasis

Antanagoge

Antapophora

Antenclema
Antepenult

Anthology

Anthorism

Antibacchius

Anticlimax

Antidactyl

Antigraph

Antimasque

Antimetathesis

Antiphrasis

Antispast

Antistrophe

Antithesis

Antonomasia

Anustubh

Aphæresis

Aphesis

Aphorism

Apocope

A podosis

Apologue

A popemptic ver

Apophoreta

A pophthegm

Aporia

Aposiopesis

Apostrophe

Apparatus criti. cus

Arbre fourchu 
Arcadia

Archaism

Archebuleanverse

Archilochian

verse

Aristophanean

verse

Arsis

Arte mayor

Artificial comedy

Arthurian cycle

Asclepiads

Asianism

Assonance

Asteism

Astrophic

Asynartete

Asyndeton

Atellan plays

Athetesis

Atmosphere

Atticism

Aubade

Aufhlärung

Augustan

Aulic, the

Aureate

Auto

Autonym

Auxesis

Bacchius

Bacchylidean

verse

Badin

Baifin

Ballad

Ballade

Ballat-royal

Barbarism
Baroque

Bas bleu

Basis

Bathos

Battology

Beast epic

Belles-lettres

Pernesque

Bestiary

l'ibliognost

- graph

- mane

- pegy

- phile

- pole

- taph

Blank verse

Blason

Blood, tragedy of

Blue-stocking

Roiscius versus

Bomphiologia

Book-piate

Pookworm

Border-thief

school

Boustrophedon

Bouts-rimés

Bow-wow theory

Bowdlerization

Brachycatalectic

Brachylogy

Broad flout, the

Broadsheet

Broadside

Brochure

Bucolics

Bull

Burana, Carmina

Burden, the
Burlesque

Burletta

Buskin

Cacemphaton

Cacosyntheton

Cacozelon

Caesura

Calliope

Canon

Cantata

Cantilène

Canto

Canzone

Cape et epée

Cardinal, the

Carmina burana

Carol

Caroline poets

Carolingian cycle

Catachresis

Catalectic

Catharsis

Causerie

Celtic revival

Cento

Chain verse

Changeling, the

Chanson de geste

Chant royal

Chap.books

Characters

Charientismus

Chaucer, school of

Chiasmus

Chorilean verse

Choliambic

Choriambus

Chorus

Chrestomatbv 
Chronicle history Coryphæus

Chronogram

Chronographia

Cinquecento

Cipher

Classical

Clausula

Cleomachean verse

Cliché

Climax

Clio

Cloka

>

Cockney school

Collaboration

Collate

Colophon

Comédie larmoy. ante

Comedy

Commedia dell' arte

Commiato

Commoratio

Common halle-

luiah metre

- long metre

- metre

- particular metre

Commus

Comparative lit.

Concatenation

Conceit

Conceptistos

Conceptismo

Conditional

Contes pieux

Coronach
Cosmic drama

Counterfeit action

- place

- time

Couple

Couple-clause

Couplet

Crasis

Cretic

Criticism of Life

Cross poem

Cryptogram

Culteranismo

Cultismo

Cultoristos

Curial, the

Curry-favell

Curtain raiser

Cycle

Cyclic poets

Dactyl

Dante, school of

Débat

Décaden $t$

Decastich

Decasyllables

Default, fig. of

Della Cruscan

Dénouement

Descort

Desis

Deus ex machina

Deuteragonist

Dialect

Diallage

Dialysis

Diastole

Diatessaron
Didactic poetry

Diiambus

Dimeter

Dirge

Disabler, the

Disguisings

Dispondeus

Disputoison

Distich

Dit

Dithyramb

Ditrochæus

Dittography

Dittology

Dizain

Dochmius

Doctrinaire

Dodecasyllables

Donne, school of

Double acrostic :

- common metre

- supply

- villanelle

Doublet

Doubtful, the

Drama

Dramatic clair. voyance

Dramatic poem

Dramatis personæ

Ecbasis

Ecbole

Echo verse

Eclecticism

Eclipis

Eclogue

Ecphonesis

Ectasis 


\section{4}

Elegy

Elegiac verse

Elision

Elizabethan

Ellipse

Emblematic

Emblems

Enallage

Enclosed rhymes

Encomia

Encyclopédistes

End-stopped

Enjambement

Enlightenment

Enterludes

Enthymeme

Entremeses

Entremets

Envoy

Epanadiplosis

Epanaphora

Epanastrophe

Epanodos

Epanorthoisis

Epanalepsis

Epenthesis

Epic

Epic cycle

Epicedium

Epiceries

Epichireme

Epigram

Epileny

Epilogue

Epimone

Epiphonema

Epiplexis

Epiploce

Episode

Epistolary style
Epistrophe

Epitaph

Epithalamium

Epithet

Epitrite

Epitrope

Epizeuxis

Epode

Épopée courtoise Erato

Erotema

Esemplastic

Esoteric

Essay

Estampie

Estrif

Ethopeia

Etiologia

Euphemism

Euphuism

Euterpe

Ex-libris

Exargasia

Exchange, fig. of

Exequy

Exodos

Exordium

Extravaganza

Fable

Fabliau

Fabula palliata

- prætextata

- togata

Facetize

Falling rhythm

Fancy, poems of

Fantastic poets

Far-fetched, the

Farce
Fatura

Feminine rhymes

Fescennine

Feuilleton

Fit

Flamboyant

Fleering frump, the

Fleshly school

Frottola

Full stress

Fustian

Galimatias

Galliambic

Gasconade

Gay science

Genethliaca

Genre

Geste, chansons de

Ghazel

Glee

Glose

Gloss

Glossary

Gnome

Golden age

(Latin)

Goliardic litera.

ture

Gongorism

Gorgeous, the

Gothic novel

Grammalopue

Grand opera

Grand style

Grangerization

Great lyric, the

Greek ending 
Grub Street

Graphica lexis

Gusto

Half-stress

Harmonies

Hebraism

Heel-treading verse

Hellenism

Hemistich

Hendecasyllabics

Hendiadys

Hephthemimeral

Hérésie de l'en. seignement

Heroic verse

Hexameter

Hexastich

Hiatus

Hieroglyphical school

Hilarotragedy

Hill-top novels

Hipponactean metre

- verse

Historiographer

History

Homeric verse

Homœeoptoton

Homœosis

Homœoteleuton

Homonymy

Horatian ode

Horismus

Hudibrastic

Huitain

Humanism

Huntsup
Hymeneal

Hypallage

Hyperbaton

Hyperbole

Hypercatalectic

$\mathrm{H}$ ypodiæresis

Hypotyposis

Physiologi

Hypozeugma

Hysteron pro. teron

Iambe

Iambics

Iambus

Icon

Ictus

Idealism

Idyll

Illuminism

Illustrious, the

Imagination, poems of

Impressionism

Imprint

Improvvisatore

Index expurga. torious

Index prohibi. torious

Induction

Inkhorn terms

Imprimatur

Insertor, the

Intercalaris versus

Interludes

Interpolation

Interruption, fig. of
Inversion

Ionic a majore

Ionic a minore

Irmus

Iron age (Latin)

Irony, Socratic

Irony, tragic

Isopets

Ithyphallic verse

Jacobean

Jagati

Jeu d'esprit

Jeu parti

Jig

Jobelins

Johnsonese

Journalese

Kailyard school

Katharsis

Kenning

Knickerbocker school

Laconic verse

Lacuna

Lai

Laisse

Lake school

Lampoon

Laureate

Leg-of-mutton school

Legend

Leonine rhyme

Leonine verse

Lesbian verse

Letter-hunting

Lever du rideau 
Libretto

Libros de cabal. lerias

Like letter, fig. of

Like loose, fig. of

Limerick

Linking-verse

Lipogram

Litotes

Livraison

Loas

Locus classicus

Logogram

Logogriph

Long-loose, fig. of

Loose-language, fig. of

Love-burden

Ludi osci

Lullaby

Lyons, school of

Lyric

Lysis

Macaronic verse

Macrology

Madrigal

Malapropism

Mannerism

Marching figure

Marinism

Marivaudage

Martinist

Martyrology

Marvels

Mascarade

Masculine rhyme

Masque

Meiosis

Meistersingers
Melic

Melodrama

Melpomene

Memoir

Memoria tech. nica

Mesozeugma

Metalepsis

Metaphor

Metaphysical school

Metaplasm

Metasiasis

Metathesis

.letonymy

Metre

Middle comedy

- marcher, the

Nimes

II miambics

Ningle-mangle

Minnesinger

Minstrel

Miracles

. Iisnamer, fig. of

Mnemonics

Mock-school, the

Ilock-heroics

Mlo erator, the

Molossus

Monodrama

Monody

Yonologue

Monometer

Monorbyme

Monostrophic

Moralities

Morbidezza

Motet

Mycterism
Mysteries

Mysticism

Myth

Namby-pamby

Neck verse

Necrology

Nenia

Neoclassic

Neologism

Neoplatonism

New comedy

New-namer, the

Notitia

Novel

Novella

Occult school

Octave

Octonarius versus

Ocular rhymes

Ode

Olla podrida

Old comedy.

Onomatopøia

Opera

Ordonnance

Ottava rima

Oxymoron

Pæan

Pæon

Pageant

Palillogy

Palimpsest

Palindrome

Palinode

Palliata

Pamphlet

Pantisocracy 


\section{7}

Pantomime

Pantoum

Parabasis

Parable

Parachronism

Paradiastole

Paradiama

Paradoxon

Parænetics

Paragoge

Paraleipsis

Paralepsis

Paraphrase

Para prosdokian

Parasiopesis

Parathesis

Parecbasis

Parembole

Paremptosis

Parenthesis

Parenthyrson

Parian verse

Parison

Parimion

Parnassiens

Parnassus

Parodos

Parody

Parœmiac verse

Parolist

Paromologia

Paronomasia

Paronymous

Parrhesia

Parthenia

Partures

Pasquinade

Passager, the

Passion play

Pastiche
Pastoral

- elegy

- romance

Patavinity

Pathetic fallacy

Pauses

Pentameter

Penthemimeral

Penult

Pericope

Periergia

Periodic style

Peripetia

Periphrasis

Petrarch, school of

Phalæcian verse

Phébus

Pherecratean verse

Philistinism

Phlyacographies

Phonogram

Picaresque

Piéce de circon. stances

Pindaric

Pindarism

Plagiary

Planh

Planipedes

Plérade

Pleonasm

Plocê

Poet laureate

Poetic moment

Political criticism

Polyhymnia

Polyonymy

Polyptoton
Pornographic lit.

Pormanteau

Port-Royal

Posy

Poulter's measure

Prætextatæ

Pragmatographia

Praxilleus versu;

Preciosity

Preposterous, the

Priapeus versus

Privy nip, the

Problem play

Procatalectic

Procatalepsis

Procatastasis

Proceleusmatic

Prodelision

Prodiegesis

Prolepsis

Proleptic

Prologue

Proode

Prooem

Prophecy, literary

Propounder, the

Prose and

Reason, age of

Prosæ

Prosodia

Prosopopœia

Prosthesis

Prosyllogi,m

Protagonist

Protasis

Prothalamium

Provence, school

of

Prozeugma

Pseudonym 


\section{8}

Pun

Purist

Purple patches

Puy

Pyrrhic

Quadratus versus

Qualifier, the

Quantity

Quasida

Quaternarius

Quatrain

Quick conceit, fig. of

Quinarius

Quintain

guodlibet

Raisonnable, Tragédie

Realism

Rear-warder, the

Rebus

Recompenser, the

Recto

Redondilla

Religious

nouveliettes

Remove. fig. of

Remplissage

Renaissance

Renascence of wonder

Rentrement

Kesponse, fig. of

Restoration

dramatists

Rhapsody

Rhétoriqueurs
Rbinthonic

comedy

Rhodianism

Rhodomontade

R hopalic verse

Rhyme royal

Rhyme

Rhythm

Riding rbyme

Riclings

Rime annexée

- bâtelée

- brisee

- concatenée

- couée

- couronnée

- empérière

- en echo

- equivoquée

- fratrisée

- insuffisante

- kyrielle

- léonine

- Normande

- pauvre

- retrogradée

- riche

- suffisante

Rimes croîsées

- embrassées

- mêlées

- plates

- redoublées

- tiercées

Ringleader, the

Ripresa

Rising rhythm

Rispetto

Rithmuscaudatus

Rococo
Roman d'aven. tures

Roman de Renard

Romance

Romancero

Romantic

Romantic revival

Rondeau

- redoublé

Kondel

Rouncifals

Rubric

Runes

Saber, El gai

Sacre rappresen-

tazioni

Sæculum rationai. isticum

Saga

Sapphic

Satanic school

Satire

Saturnian verse

Satyric drama

Saynetes

Scald

Scansion

Scatology

scazon

Scene

Scholasticism

scholiast

School of Pro.

vence

Schoolmen

Science, the gay

Scolion

Scôp 


\section{9}

Sdruccioli

Seicento

Senarius

Sentimental

comedy

Septenarius

versus

Sequentiæ

Sermon joyeux

Serpentine

Service metre

Sesquipedalian

Sestet

Sestina

Sirventois

Silence, fig. of

Silver age (Latin)

Silver-fork school

Simile

Single supply,

fig. of

Sinking

Sixain

Skeltonical

Skolion

Smectymnuus

Sock

Socratic irony

Socratic method

Solecism

Soliloquy

Sonnet

Soraismus

Sotadic verse

Sottie

Spanish school

Spasmodic scbool

Spenser, school of

Spenserian stanza

Spondee
Spondiacus versus

Stanza

Stasimon

Stichomythia

Storm and Stress

Stornello

Strophe

Sturm und Drang Style

Substitute, the

Submutatio

Sung-verse

Surnamer, the

Sword and cloak romances

Syllepsis

Symbolism

Symbolistes

Symploce

Symposium

Synæresis

Synalæpha

Synathrosmus

Syncope

Synecdoche

Synesis

Synizesis

Synonym

Systole

Table-talk

Tags.

Tapeinosis

Tautology

Telestic verse

Telestich

Tel!-cause the

Tenson

Tercet
Terpsichore

Terza rima

Terzetti

Terzina

Tetralogy

Tetrameter

Tetrastich

Thalia

Thesis

Threnos

Tmesis

Togatæ

Top-shelf lit.

Topographia

Toscanaggiamento

Touchstone method of criticism

Tragédie bour. geoise

Tragédie raison. nable

Tragedy

$\rightarrow$ of blood

Tragi-comedy

Tragic irony

Transport, fiz. of

Trespasser, the

Triad

Triban

Tribrach

Trilogy

Trimeter

Triolet

Trionfi

Triplet

Tristubh

Tritagonist

Triumphal 


\section{0}

Trobar clus

Trochaics

Trochee

Troilus verse

Trojans

Trope

Troubadour

Tumbling verse

Turkey-carpet style

Twins, fig. of

Ultra crepidarian critics
Unities

Urania

Uranistes

Utopia

Vers Eumolpiques Wit-writing

- libéré

- libres

- mésurés

Verso

Vice

Villanelle

Virelai

Volkslieder
Wardour Street

Waverley novels

Wertherism

Wessex novels

Wit

Wit-written

Yellow journalism

Zeugma 




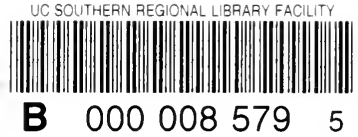


